\title{
WestVirginiaUniversity
}

THE RESEARCH REPOSITORY @ WVU

Graduate Theses, Dissertations, and Problem Reports

2006

\section{Geomechanical and weathering properties of weak roof shales in coal mines}

Hakan Gurgenli

West Virginia University

Follow this and additional works at: https://researchrepository.wvu.edu/etd

\section{Recommended Citation}

Gurgenli, Hakan, "Geomechanical and weathering properties of weak roof shales in coal mines" (2006). Graduate Theses, Dissertations, and Problem Reports. 1730.

https://researchrepository.wvu.edu/etd/1730

This Thesis is protected by copyright and/or related rights. It has been brought to you by the The Research Repository @ WVU with permission from the rights-holder(s). You are free to use this Thesis in any way that is permitted by the copyright and related rights legislation that applies to your use. For other uses you must obtain permission from the rights-holder(s) directly, unless additional rights are indicated by a Creative Commons license in the record and/ or on the work itself. This Thesis has been accepted for inclusion in WVU Graduate Theses, Dissertations, and Problem Reports collection by an authorized administrator of The Research Repository @ WVU. For more information, please contact researchrepository@mail.wvu.edu. 


\title{
GEOMECHANICAL AND WEATHERING PROPERTIES OF WEAK ROOF SHALES IN COAL MINES
}

\author{
Hakan Gurgenli
}

\author{
Thesis submitted to the \\ College of Engineering and Mineral Resources \\ at West Virginia University \\ in partial fulfillment of the requirements \\ for the degree of \\ MASTER OF SCIENCE \\ IN \\ MINING ENGINEERING
}
Syd S. Peng, Ph.D., Chair
Keith Heasley, Ph.D.
Yi Luo, Ph.D.
Morgantown, West Virginia
2006

Keywords: weak rocks, shales, moisture sensitive rocks, weathering of roof rocks, mine design considerations for weak and moisture sensitive roofs. 


\section{ABSTRACT}

\section{Geomechanical and Weathering Properties of Weak Roof Shales in Coal Mines Hakan Gurgenli}

Many coal seams have weak shale immediate roofs that cause ground control problems. Therefore, it is important to know the mechanical properties of these shales so that preventive measures can be developed in advance. However, it is sometimes hard to understand this rock type due to its unpredictable behavior. A good example of this situation is found with the shale roof strata in two coal mines located in the Illinois coal basin - Herrin No. 6 seam. Although these mines are located very close to each other, one of them has many roof falls, whereas the other has no measurable ground control problems.

The aim of this thesis is to explain why and how one shale roof behaves worse than the other. Laboratory tests, including point load strength index, slake durability index, moisture activity index, weatherability index, water (moisture) content determination, swelling strain and $x$-ray diffraction tests were performed to analyze the shale properties. As a result of these tests, strength, durability, water (moisture) content and absorption, weatherability, swelling and mineralogy of weak shales were analyzed. According to these analyses, some useful correlations were found between the engineering properties, moisture-sensitivity indices, and weathering properties of shales. Finally, mine and support design considerations based on the test results were discussed and recommendations to prevent ground control problems were given. 
To the 3A's of my life:

Annem,

Ablam, $\&$

Aslım. 


\section{ACKNOWLEDGEMENTS}

First of all, I wish to express my sincere appreciation and gratitude to those who have contributed to the completion of this thesis. I would like to express my appreciation to my advisor, Prof. Syd Peng, for his great support throughout this study. His innovative suggestions, truth-seeking attitude and excellent supervision were invaluable to the completion of this research. I would also like to thank to the other committee members, Dr. Keith Heasley and Dr. Yi Luo for their support and suggestions.

Furthermore, I would like to thank Dr. Takashi A. J. Sasaoka for his creative technical advices, complimentary help and solid friendship. I would like to extent my appreciations to the staff of NIOSH, Pittsburgh Research Laboratory, to Dr. Christopher Mark for giving me the opportunity to join his research group and for showing outstanding supervision and to Gregory Molinda for giving me his invaluable practical experience. Besides, I also wish to express my thanks to the fellow students and staff of CEMR for their help, especially to Dr. Yunqing Zhang, who assisted in initiating this research project.

Special thanks are given to my old friend Emre Artun for his friendship and technical support. Also, I would like to thank the band members of AnorexiA, Ulas Kuvanc, Burak Demir and Firat Kalecik for their great friendship.

Finally, I would like to thank my family, especially my mother, sister, and cousin for their full support and belief in me in every stage of my life. My very special thank goes to my love for being so nice to me and showing great patience in waiting for me back home. 


\section{TABLE OF CONTENTS}

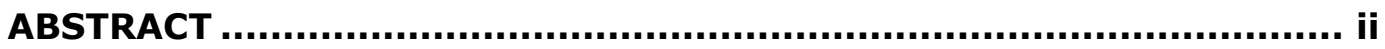

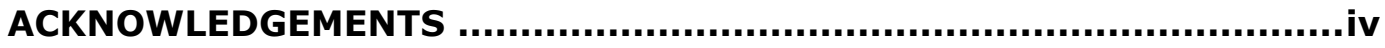

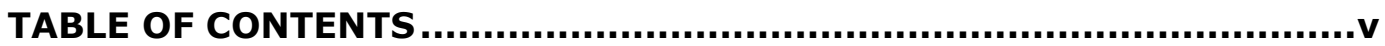

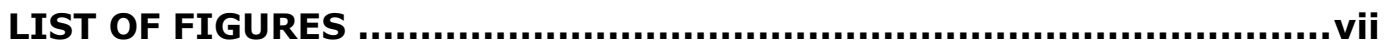

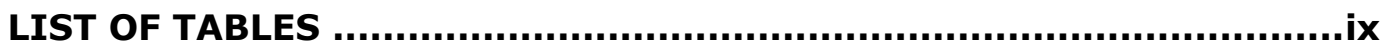

CHAPTER 1: $\quad$ Introduction ............................................................. 1

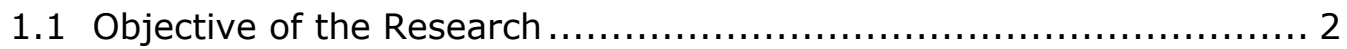

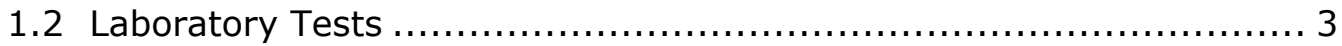

1.3 Information about the Mines \& Geology of the Area ..................... 4

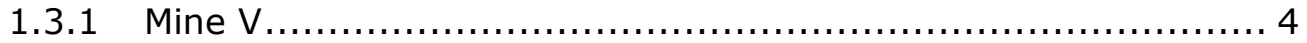

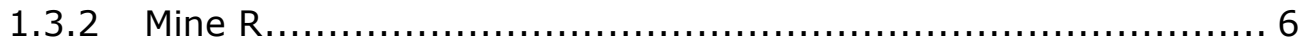

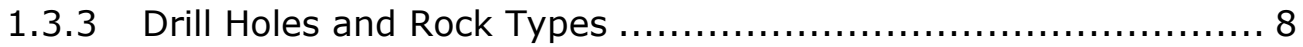

CHAPTER 2: $\quad$ Literature Review .................................................. 12

CHAPTER 3: Laboratory Tests ............................................... 23

3.1 Common Tests Performed on Shales ................................. 23

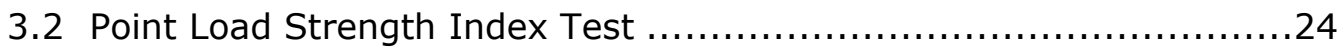

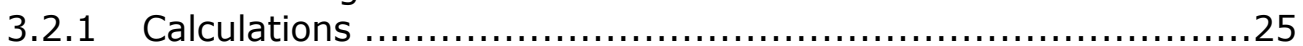

3.3 Slake Durability Index Test ............................................ 26

3.3.1 Testing Procedure and Calculations ..............................

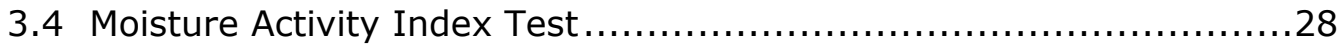

3.4.1 Testing Procedure and Calculations................................. 28

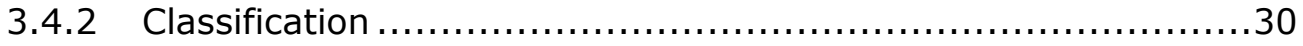

3.5 Water (Moisture) Content Determination Test......................... 30

3.5.1 Testing Procedure and Calculations ............................... 30

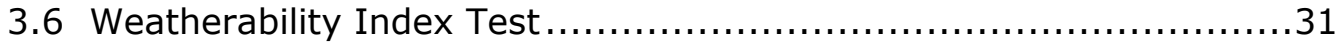

3.6.1 Testing Procedure and Calculations ................................. 


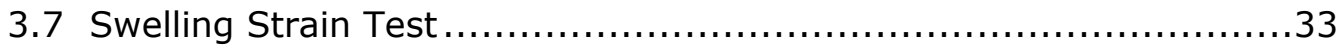

3.7.1 Testing Procedure and Calculations............................... 34

3.8 X-ray Diffraction Test.......................................... 35

CHAPTER 4: Results \& Discussion ........................................... 37

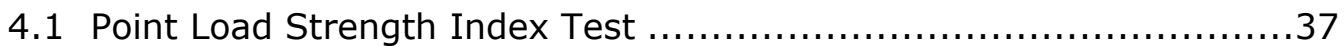

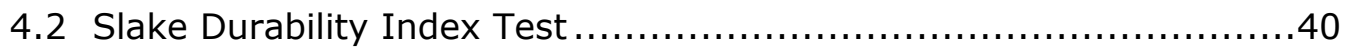

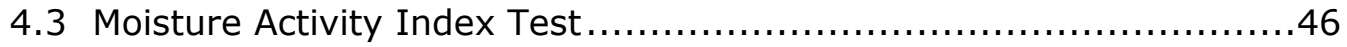

4.4 Water (Moisture) Content Determination Test........................50

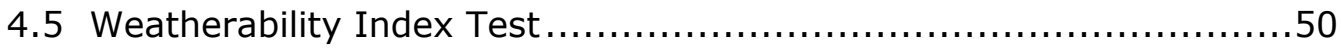

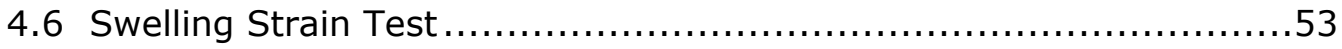

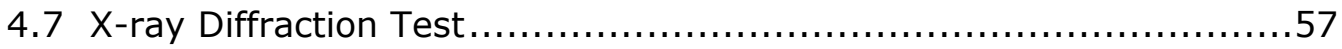

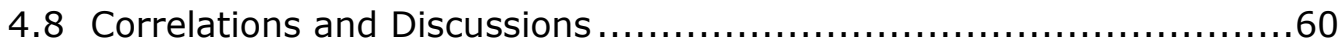

CHAPTER 5: Design Considerations ..................................... 68

CHAPTER 6: Conclusions ............................................................ 73

REFERENCES

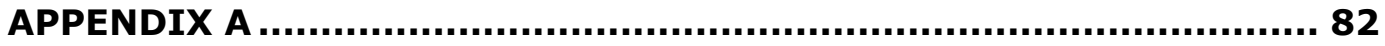

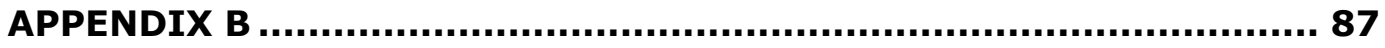

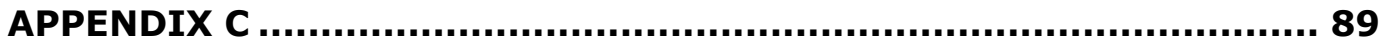

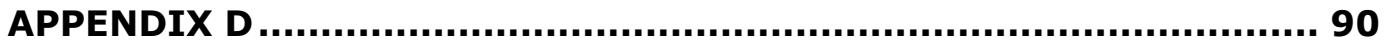

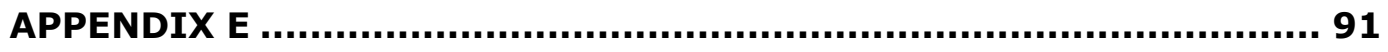

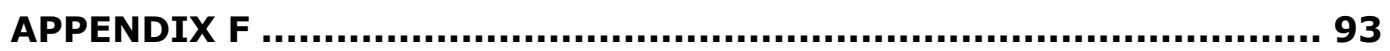

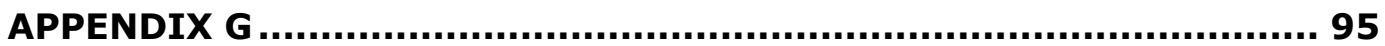




\section{LIST OF FIGURES}

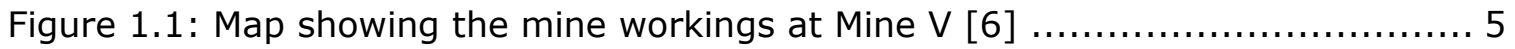

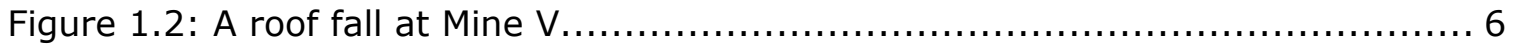

Figure 1.3: Map of Mine R showing the areas of different bolt patterns and thick

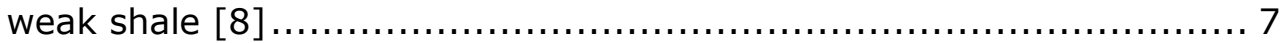

Figure 1.4: Geologic columns of the drill holes from Mine V $\ldots \ldots \ldots \ldots \ldots \ldots \ldots \ldots \ldots . \ldots$

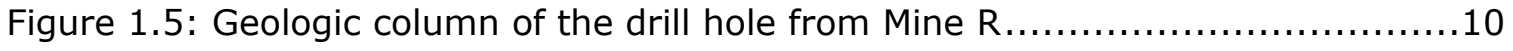

Figure 2.1: Shales and related sedimentary rocks [3] .............................. 14

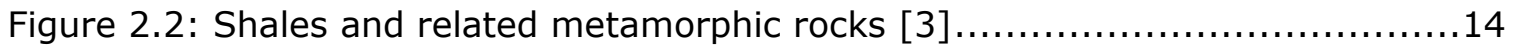

Figure 2.3: Classification and geological consideration of shales [3].................. 15

Figure 2.4: Decrease of the uniaxial compressive strength with increase of humidity

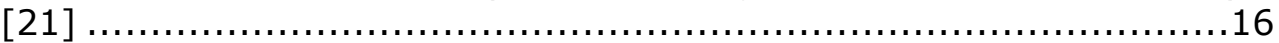

Figure 2.5: Unconfined swelling strains as a function of time for gray shale [30] ...18

Figure 2.6: A comparison of total roof falls and absolute humidity [30] ...............21

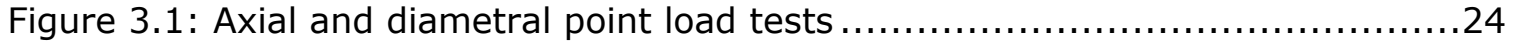

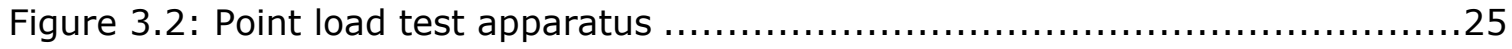

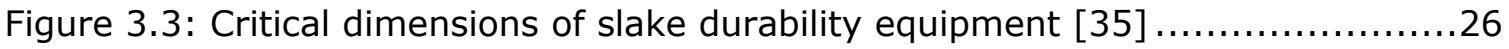

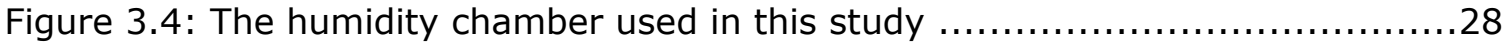

Figure 3.5: Moisture activity index term [22] ....................................... 29

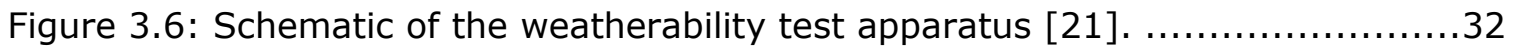

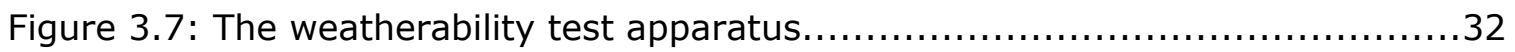

Figure 3.8: The swelling strain test apparatus; humidity chamber (including steel plate), dial indicator and magnetic holder .............................. 34

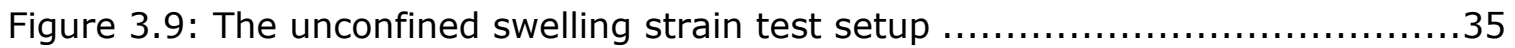

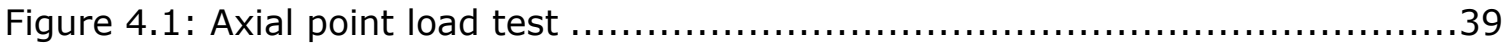

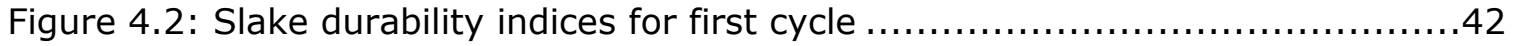

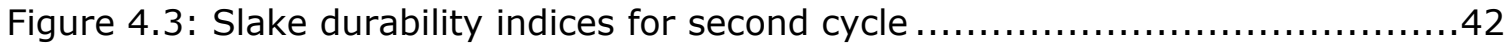

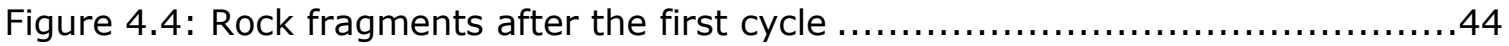

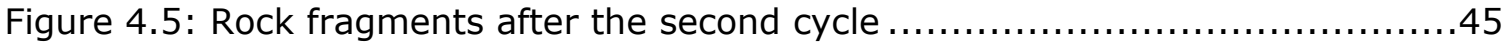




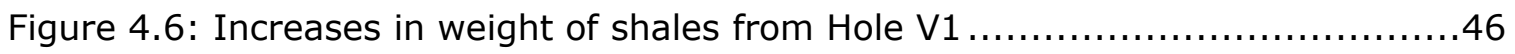

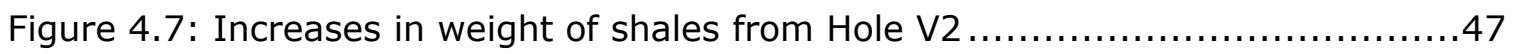

Figure 4.8: Increases in weight of shales from Hole R...........................47

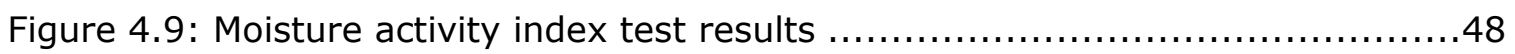

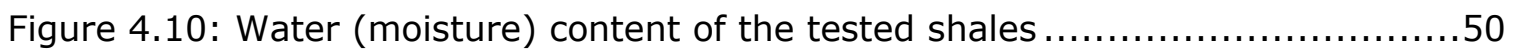

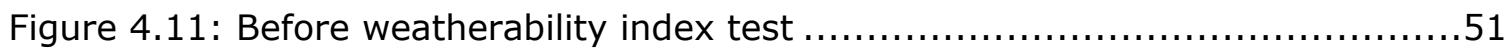

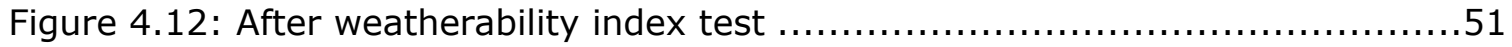

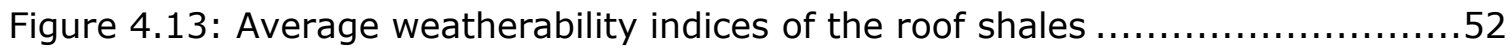

Figure 4.14: Weatherability index results of the roof rocks of 11 U.S. coal mines

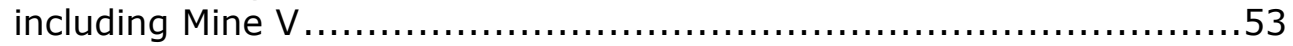

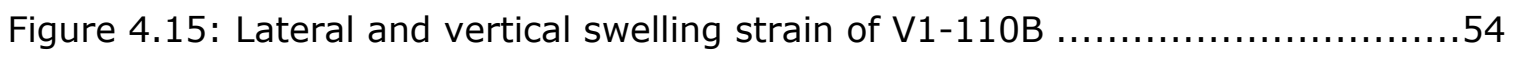

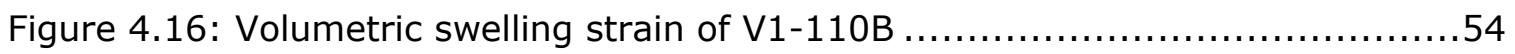

Figure 4.17: Lateral and vertical swelling strain of $\mathrm{V} 2-132$ and $\mathrm{R}-136 \ldots \ldots \ldots \ldots \ldots . \ldots 55$

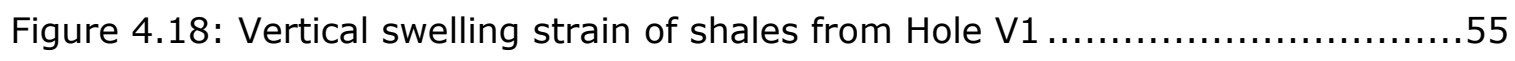

Figure 4.19: Vertical swelling strain of shales from Hole V2 ........................56

Figure 4.20: Vertical swelling strain of shales from Hole R............................56

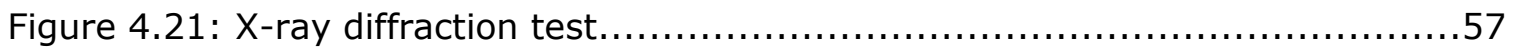

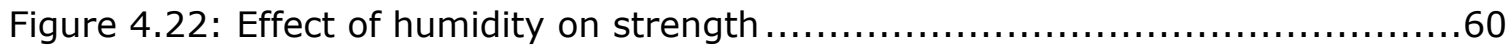

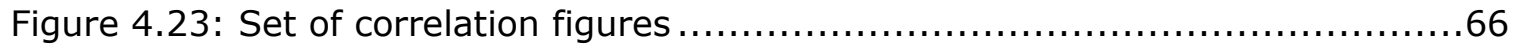

Figure 5.1: Moisture loss of the shale samples subjected to room atmosphere $\ldots . . .71$

Figure E.1: Before (left hand side) and after (right hand side) weatherability index test of roof rocks of 11 U.S. coal mines ................................ 92

Figure G.1: Mineral composition of V1-132A .................................. 96

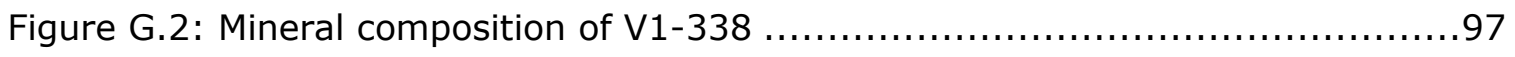

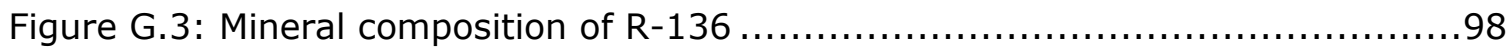

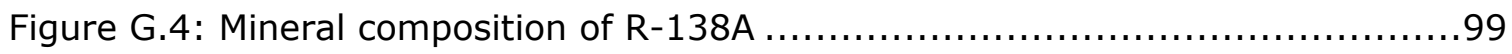




\section{LIST OF TABLES}

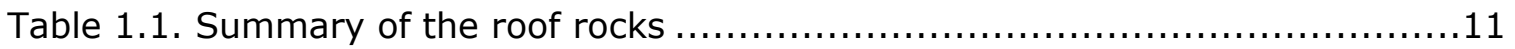

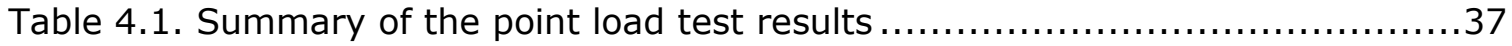

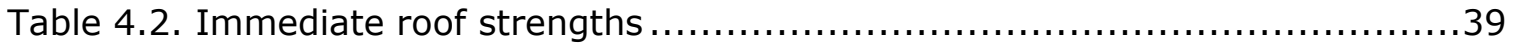

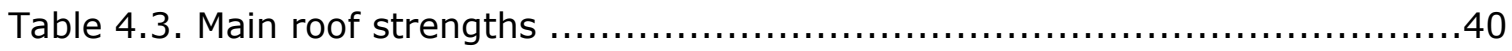

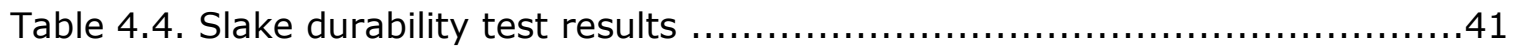

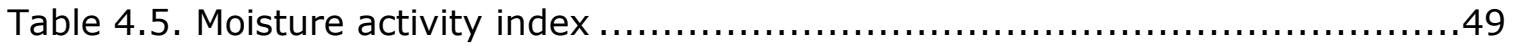

Table 4.6. Minerals found by $x$-ray diffraction test................................60

Table 6.1 . Summary of the test results............................................

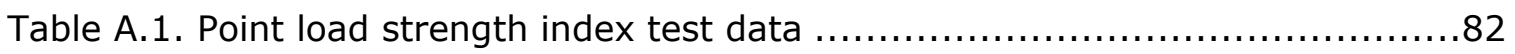

Table A.2. Statistics summary for the immediate roofs $\ldots \ldots \ldots \ldots \ldots \ldots \ldots \ldots \ldots \ldots \ldots \ldots$

Table A.3. Statistics summary for the main roofs .................................... 85

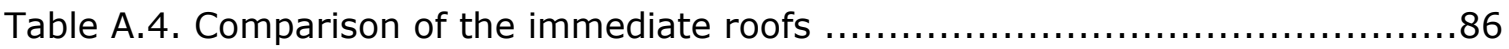

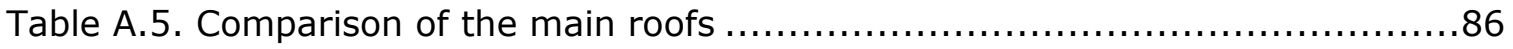

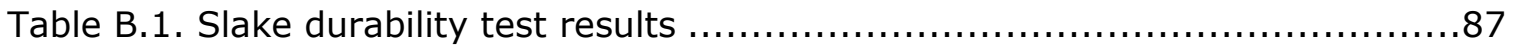

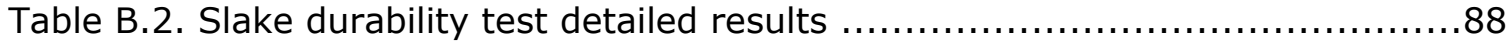

Table C.1. Moisture activity index test detailed results $\ldots \ldots \ldots \ldots \ldots \ldots \ldots \ldots \ldots \ldots \ldots \ldots \ldots$

Table D.1. Water (moisture) content calculation results .......................... 90

Table E.1. Weatherability index test results..................................... 91

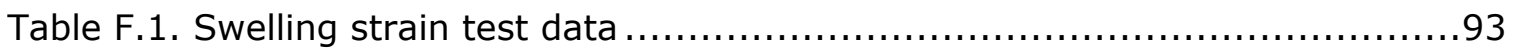




\section{CHAPTER 1: INTRODUCTION}

Weak rocks are problematic materials for engineers because it is very difficult to describe them, apply engineering tests to them, and understand their behaviors. According to the International Society of Rock Mechanics, the uniaxial compressive strength of the weak rocks is between $2 \mathrm{MPa}$ and $20 \mathrm{MPa}$ (290 psi and $2900 \mathrm{psi}$ ) [1]. The lower limit, which is 290 psi, is the boundary between rocks and soils. As an engineering material, "soil" is considered to be an aggregate of mineral grains which can be readily separated by gentle mechanical means. On the other hand, "rock" is taken as an aggregate of grains that are strongly bound to each other [2].

Shale is the most common sedimentary rock in the earth's crust. The term shale is used to designate all argillaceous sediments consisting of claystone, siltstone, mudstone, and marl; however, some scientists designate the larger group as the mudstone, or mudrock group, and classify shale as a member of that group. In fact, shale is the boundary material between soil and rock [3]. Shales are the most difficult rocks to classify, sample, test and get reliable data for engineering design since they are on this boundary. It is extremely important to know their geomechanical and time dependent behaviors for mining and civil engineers while designing mines, dams, tunnels, etc. Their behavior should be well-known in order to prevent accidents and to save time and money.

Many underground coal mines have shale roofs that cause severe ground control problems. These shales are usually moisture sensitive and create unexpected roof falls. Therefore, mining engineers must know the properties of these shales completely in order to support a weak roof safely and cost-effectively. However, these shale properties and behavior are still not well understood. Thus, currently much research is performed by scientists to solve shale related problems.

This research includes the results of laboratory tests to determine the geomechanical and weathering properties of weak shales. Mechanical properties are 
those used in engineering design. Weathering properties have direct effects on the mechanism of the rock behavior. Weathering of roof strata refers to those changes that occur in the rock due to the contact with the mine atmosphere or in some cases to the changes caused by the combined action of ground water and the mine atmosphere [4].

After the completion of the laboratory tests, a detailed analysis was made and discussions were given related to the mining engineering field. The main part of this research was completed at the rock mechanics laboratories of the Department of Mining Engineering at West Virginia University. Also, some data and results from the research that was conducted at the National Institute for Occupational Safety and Health (NIOSH), Pittsburgh Research Laboratory (PRL) was also included in this thesis.

\subsection{Objective of the Research}

This research consists of the analysis of two coal mine roofs located in the Illinois coal basin - Herrin No. 6 coal seam. These coal mines are just a few miles away from each other. In this study, they are named as Mine R and Mine V. Both of these mines have similar shale main and immediate roofs that could cause ground control problems. This weak shale roof situation is commonly seen in many underground coal mines all around the world and it is a crucial problem that should be solved in order to prevent roof falls and various accidents. However, in this case Mine $\mathrm{V}$ has more roof falls and more severe ground control problems than Mine $\mathrm{R}$. This is considered to be a special case that has to be analyzed in detail since the geology and other conditions of these mines appear very similar to each other.

The main objective of this research is to understand the properties that make one shale roof worse than the other one. Other objectives are listed as follows:

- To find relationships between geomechanical and index properties

- To obtain correlations between strength, durability, water (moisture) content and absorption, weatherability, swelling and mineral content

- To figure out the best laboratory testing procedure of weak and moisture sensitive rocks 
- To explain the behavior of shales

- To propose solutions for the ground control problems caused by moisture sensitive and weak rocks

These objectives are very important to the mining and geotechnical engineering fields and a positive contribution to the explanation of the weak and moisture sensitive shale behavior would be invaluable to these areas. In order to achieve the goals mentioned above, core samples that were taken from three different drill holes were tested in the laboratories. Two of these holes, named as Holes V1 and V2, are from Mine V and the other one, named as Hole R, is from Mine R. The stratigraphic sequences of these holes are illustrated in Section 1.3.3.

\subsection{Laboratory Tests}

The laboratory tests listed below were performed in this research by following the ASTM or ISRM standards when it is available:

1) Point load strength index test

2) Slake durability index test

3) Moisture activity index test

4) Water (moisture) content determination test

5) Weatherability index test

6) Swelling strain test

7) X-ray diffraction test 


\subsection{I nformation about the Mines \& Geology of the Area}

The Illinois basin coal field covers more than 65 percent of the state of Illinois. The coal field is in all of central and southern Illinois, along with adjacent small portions of southwestern Indiana and western Kentucky. All commercial coal in this basin occurs in the strata of the Pennsylvanian System. This system generally reaches a thickness of $2500 \mathrm{ft}$ in the central part of the Illinois basin. A thickness of up to $3500 \mathrm{ft}$ has been recorded locally at down-faulted blocks in southeastern Illinois and western Kentucky. The Pennsylvanian System is the youngest large bedrock system in the basin and it contains a major coal formation, which is called the "Carbondale Formation". In the state of Illinois, $92 \%$ of the identified resources occur in this formation [5].

The Herrin No. 6 coal seam is also in the Carbondale Formation. The coal seam is located at the upper portion of the formation. This seam has a maximum thickness between 10 to $12 \mathrm{ft}$, and a maximum depth of $650 \mathrm{ft}$. It is overlain by the immediate roof rocks of claystone, calcareous clay shale or silty shale. The immediate floor is underclay, silty shale and sandstone [5].

\subsubsection{Mine V}

As it is mentioned above, Mine $\mathrm{V}$ is located in the Illinois coal basin and the coal seam is called the Herrin No. 6. The mine layout is shown in Figure 1.1. The immediate roof of the mine is a "Varve", which is a very thinly laminated type of shale. This shale type is soft and slippery to touch and can be scratched by finger nails. The Varve is 5-6 ft thick in the west and 8-9 ft thick in the northeast of the mine. There are thin films of darker siderite layers that tend to form the roof top or, when roof falls occur, the top of the cavities. Overlying the Varve there are shales of varying thickness and occasionally sandstone. The floor is unconsolidated clay of varying thickness.

The mine began production in September 2001. The average thickness of the coal and the average depth of the mine are approximately $5.8 \mathrm{ft}$ and $240 \mathrm{ft}$, respectively. Entries/crosscuts were developed using a super-section layout: two continuous miners, with two roof bolters, one on each side. 


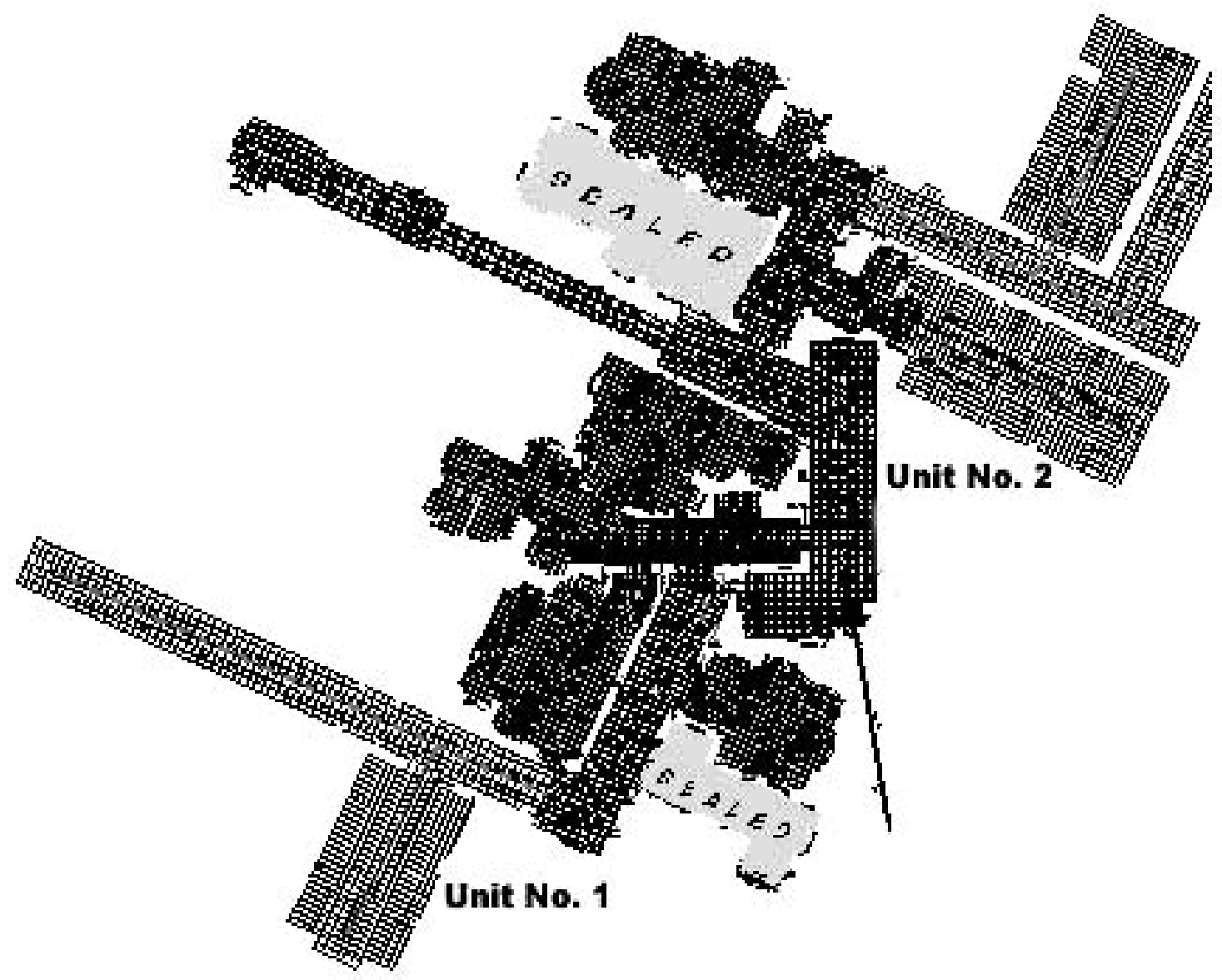

Figure 1.1: Map showing the mine workings at Mine V [6]

According to MSHA data, 12 reportable roof fall accidents had been recorded at Mine V from January 2002 till December 2003. A detailed analysis was done by the Department of Mining Engineering at West Virginia University in 2004 and very serious ground control problems were observed throughout this study. Some of the pictures of the observed roof falls are shown in Figure 1.2. The following was stated about the roof falls according to this observation: the roof falls sometimes occurred about one week after mining, they occurred randomly either at the intersections or between pillars, they began normally less than one block in size and then connected to become stepwise, they were more often oriented in the NS direction than in the EW direction, they were either 5-6 ft high or more than $9 \mathrm{ft}$ high. In the former case, roof bolts were still hanging, while in the latter case the falls were above the bolting horizon. The edges of the roof fall were vertical or near vertical, both sides either along the ribs or one side along the side bolt. The top was generally a smooth and darker plane [6]. 

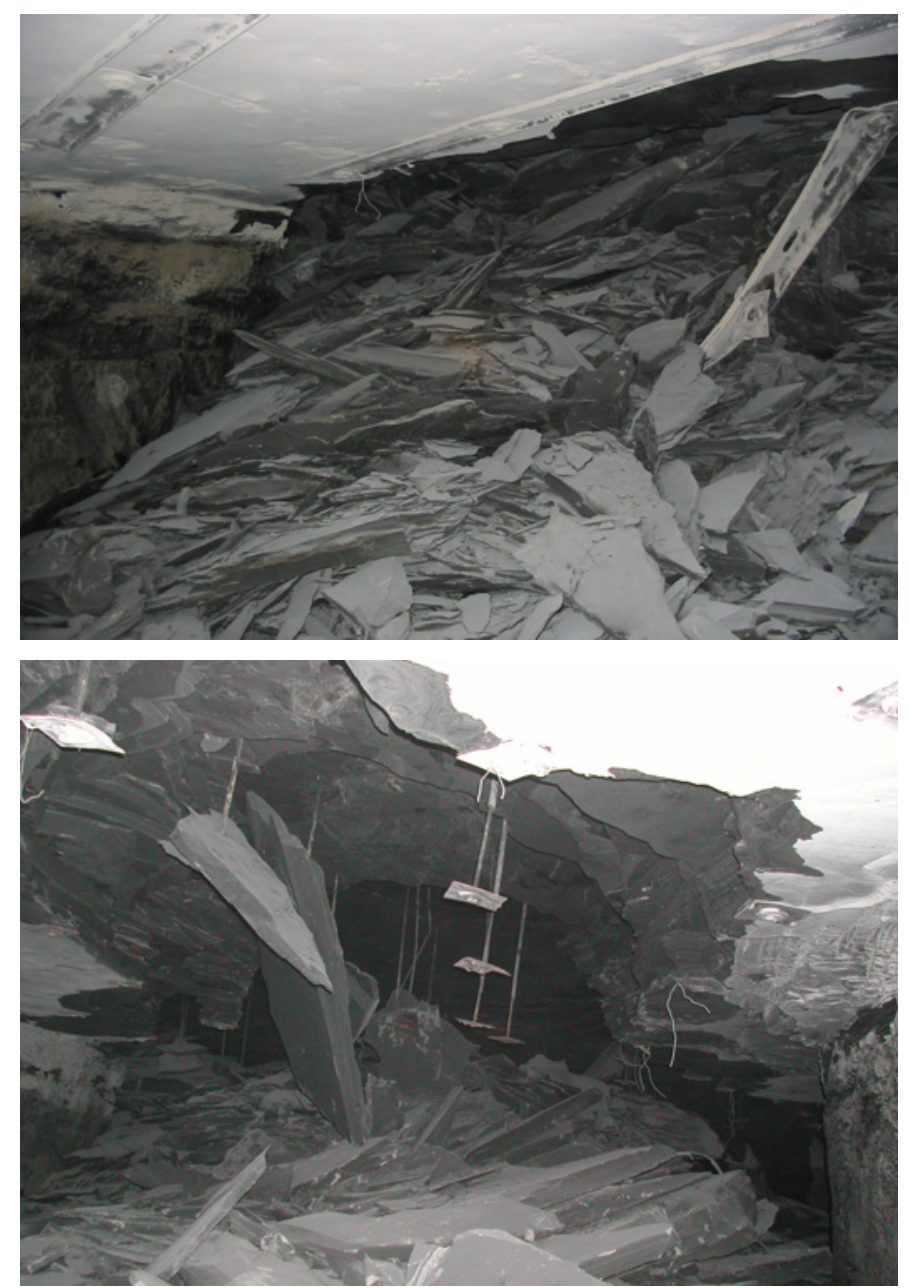

Figure 1.2: A roof fall at Mine $V$

\subsubsection{Mine $\mathbf{R}$}

Mine $\mathrm{R}$ is also located in the Herrin No. 6 seam and it is only a couple of miles away from Mine $V$, but its roof condition is better than Mine $V$. The roof is the same rock as the shale which overlies the Varve at Mine $V$. However, the Varve is not present at Mine R. This mine has a weak shale roof and bedding is also weak. Cutters are present but much less frequent and severe than Mine $V$ [7]. Two continuous miner sections are extracting the coal seam, using room-and-pillar methods with no secondary extraction. The seam height is approximately $5.5 \mathrm{ft}$ and the depth of cover is about $250 \mathrm{ft}[8]$.

The mine layout and roof bolting patterns are illustrated in Figure 1.3. Bolt Pattern 1 is: three, 8-ft long, \#7 resin-assisted point anchor bolts; with two, 6-ft 
long, \#5 fully-grouted rebar; with $16 \mathrm{ft}$ steel straps; Bolt Pattern 2 is: two, 12-ft long, \#7 resin-assisted point anchor bolts; with three, 5-ft long, resin-assisted point anchor bolts; with either $14 \mathrm{ft}$ steel straps or wire mesh (5'x15' panels, of 8 Gauge wire with 4" square openings), and; Bolt Pattern 3 is: $6 \mathrm{ft}$ long, \#5 fully-grouted rebar, 5 per row.

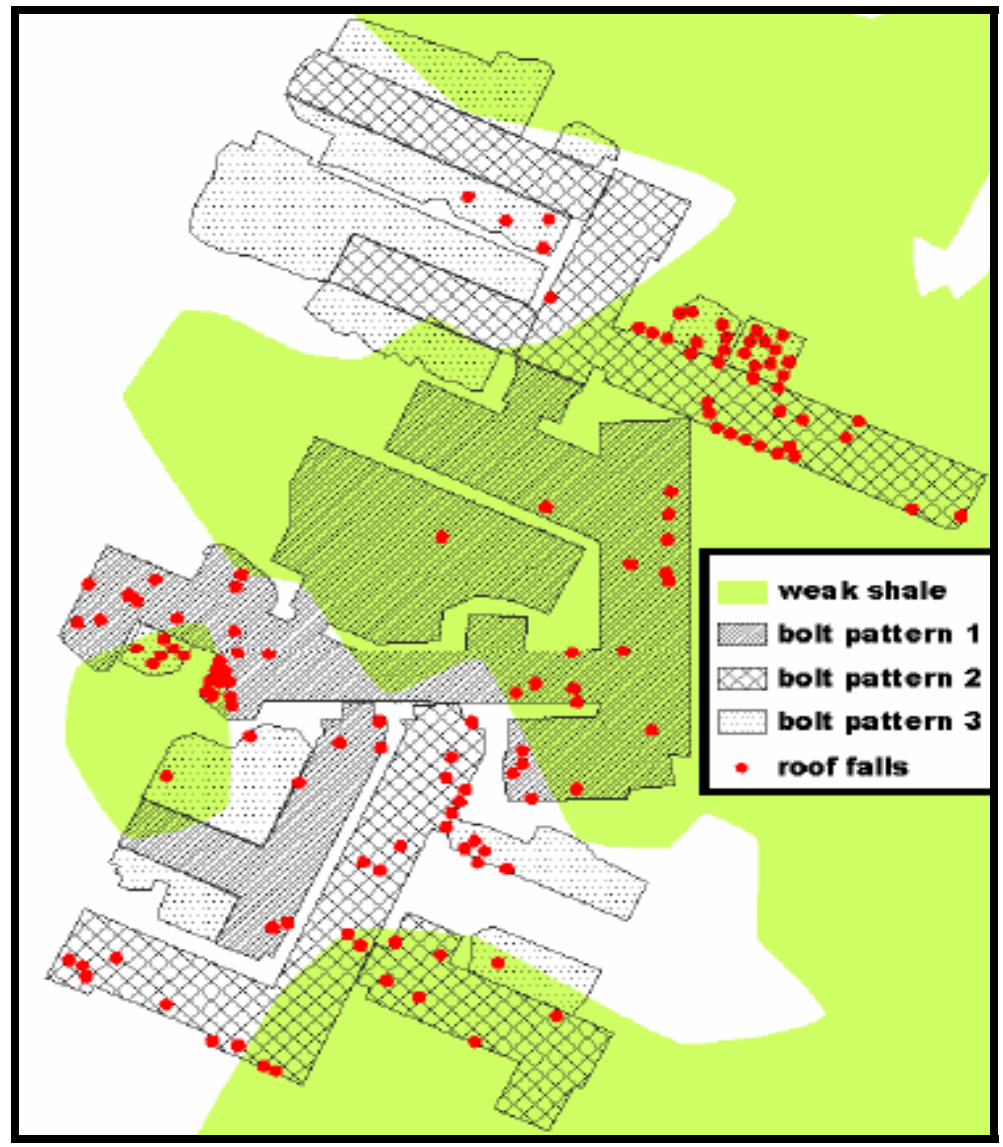

Figure 1.3: Map of Mine $R$ showing the areas of different bolt patterns and thick weak shale [8]

Underground observations indicated that a typical sequence of events leading to a roof fall might be as follows [8]:

- On development, a cutter forms on one side of the entry

- As the cutter works its way up into the roof, the rock around the roof bolt plates nearest the cutter tends to unravel. If the bolts are point-anchor, they may lose their effectiveness when the bearing plate no longer contacts the roof. 
- If the cutter works its way above the bolts, a roof fall may occur. In cases where only the rib side long bolt had lost its plate load, the fall may be just $6 \mathrm{ft}$ high, and extend half way across the entry.

According to MSHA data, 9 reportable roof fall accidents had been recorded at Mine R from July 1996 till October 2002. This means that more roof fall accidents had been observed in Mine $\mathrm{V}$ in less than 2 years compared to the roof fall accidents happened in Mine $\mathrm{R}$ in 6 years.

\subsubsection{Drill Holes and Rock Types}

The geologic columns of the tested drill holes (Holes V1, V2 and R) and the Ferm Numbers of each rock type in these columns are illustrated in Figures 1.4 and 1.5. Also, a brief summary of the roof rocks is given in the Table 1.1. Unfortunately, a lost core section was found in the drill hole of Mine $R$ and this section could not be analyzed.

The rock types in this study are classified according to the Ferm Classification Numbers. Ferm and Weisenfluh [36] developed a number system classification for coal measure rock types using color photographs of rock core in an index guide. This classification method has been widely accepted as a means for consistent rock identification and it is very useful in this kind of study because it makes it easier to read and compare the data. Moreover, a rock code system was developed for this study to represent the samples clearly. Namely, V2-132 refers to the rock from the second hole of Mine V, which is V2 and its Ferm Number is 132.

According to the hole data, the immediate roof of Mine $\mathrm{V}$ mainly consists of the shale type having a Ferm Number of 132. Shales with Ferm Number of 110 are only seen in the Hole V1. Also, shales with 338 and 133 Ferm Numbers are also present in the immediate roof of Mine V. On the other hand, Mine R has 136 and 138 Ferm Numbered shales in its immediate roof. The main roof of Mine $\mathrm{V}$ includes 133, 138 and 333. Similarly, the main roof of Mine R consists of 138 and 333. 


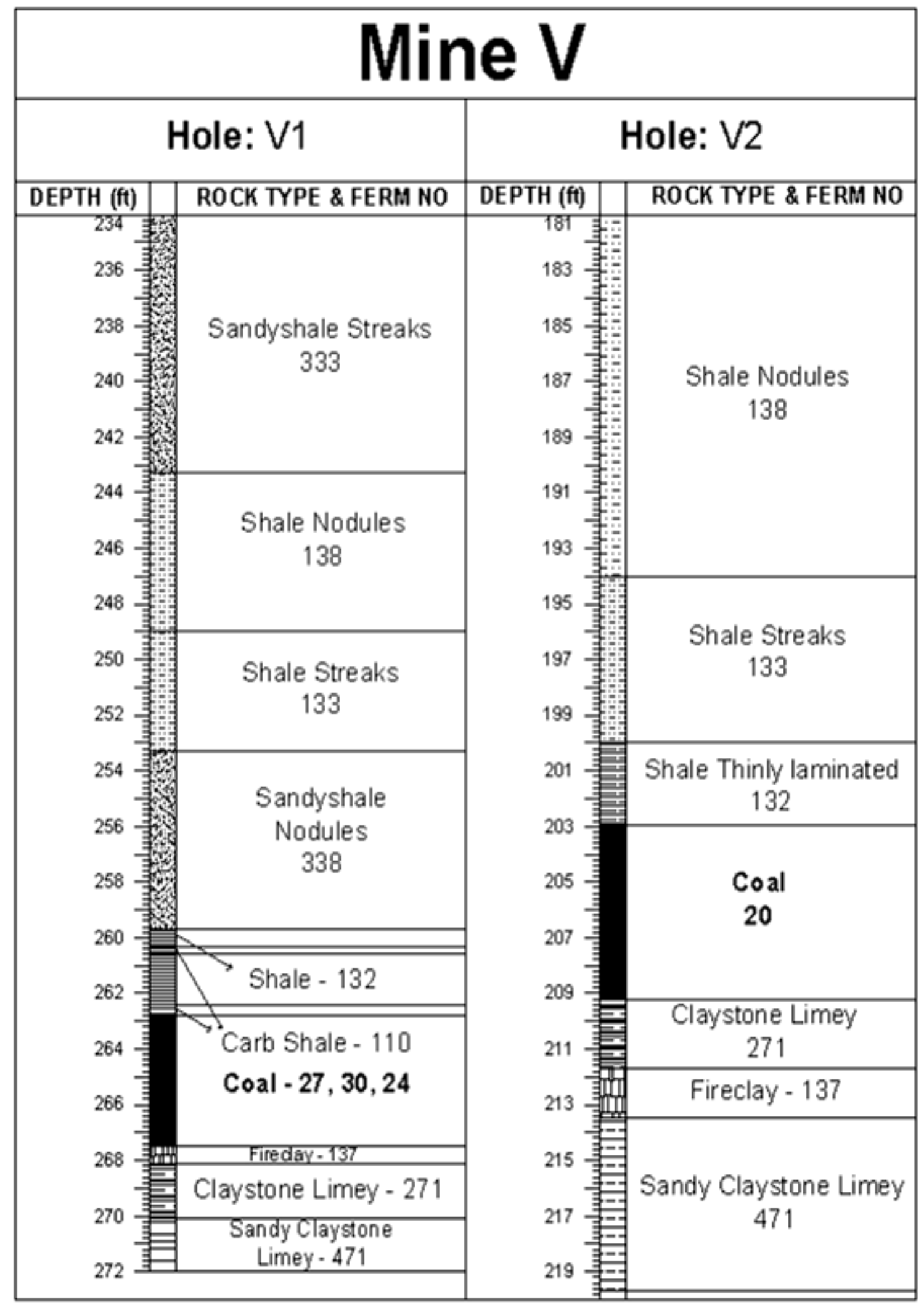

Figure 1.4: Geologic columns of the drill holes from Mine V 


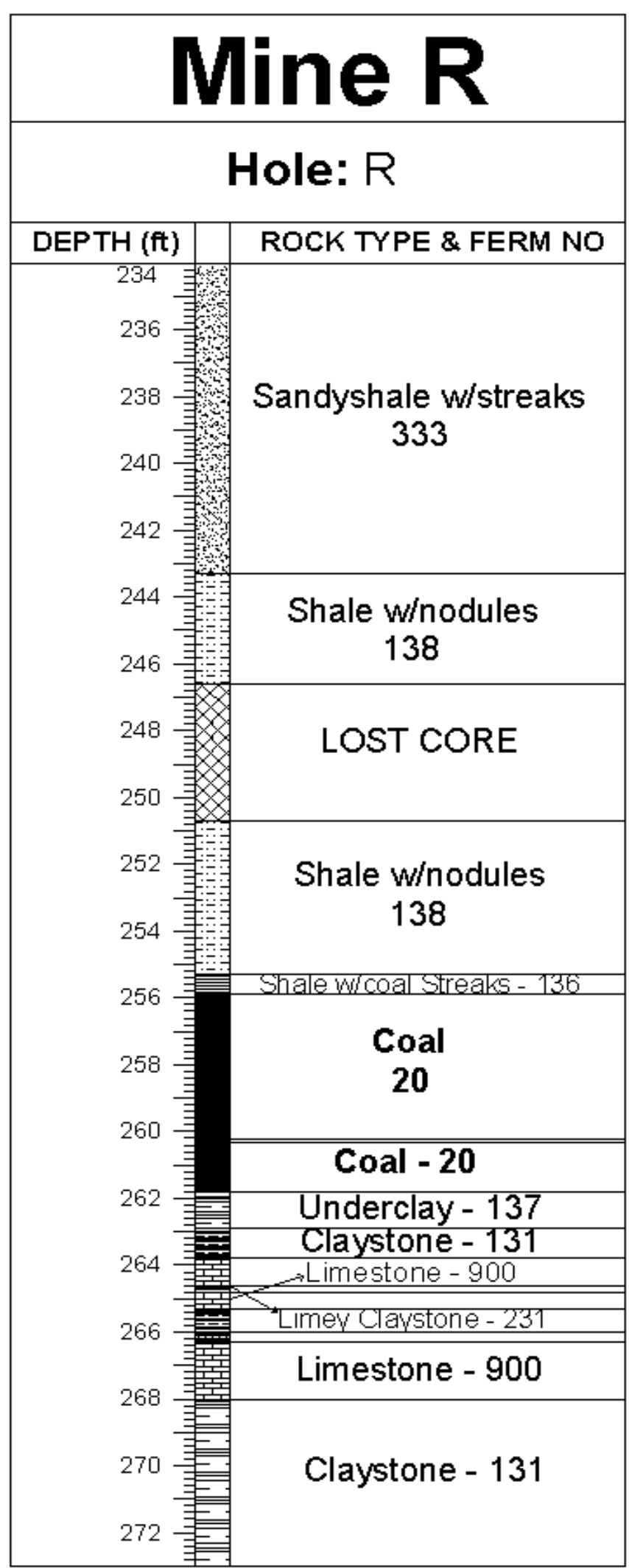

Figure 1.5: Geologic column of the drill hole from Mine R 
Table 1.1. Summary of the roof rocks

\begin{tabular}{|c|c|c|c|c|c|c|c|c|}
\hline Mine & Hole & $\begin{array}{l}\text { Rock } \\
\text { Name }\end{array}$ & $\begin{array}{c}\text { Ferm } \\
\text { Number }\end{array}$ & $\begin{array}{l}\text { Rock } \\
\text { Code }\end{array}$ & $\begin{array}{c}\text { From } \\
\text { (ft) }\end{array}$ & $\begin{array}{l}\text { To } \\
\text { (ft) }\end{array}$ & \begin{tabular}{|} 
Thickness \\
(ft)
\end{tabular} & $\begin{array}{c}\text { Distance } \\
\text { To Coal } \\
\text { Seam } \\
\text { (ft) }\end{array}$ \\
\hline \multirow{11}{*}{$\underset{\substack{\Sigma \\
\Sigma}}{>}$} & \multirow{8}{*}{$\begin{array}{l}\frac{5}{0} \\
\frac{0}{0}\end{array}$} & Carbonaceous Shale & 110 & V1-110A & 262.4 & 262.8 & 0.4 & 0.0 \\
\hline & & Shale & 132 & V1-132A & 260.6 & 262.4 & 1.8 & 0.4 \\
\hline & & Carbonaceous Shale & 110 & V1-110B & 260.3 & 260.6 & 0.3 & 2.2 \\
\hline & & Shale & 132 & V1-132B & 259.7 & 260.3 & 0.6 & 2.5 \\
\hline & & Sandyshale w/nodules & 338 & V1-338 & 253.3 & 259.7 & 6.4 & 3.1 \\
\hline & & Shale w/streaks & 133 & V1-133 & 249.0 & 253.3 & 4.3 & 9.5 \\
\hline & & Shale w/nodules & 138 & V1-138 & 243.3 & 249.0 & 5.7 & 13.8 \\
\hline & & Sandyshale w/streaks & 333 & V1-333 & 234.0 & 243.3 & 9.3 & 19.5 \\
\hline & \multirow{3}{*}{$\begin{array}{l}\text { N } \\
\frac{0}{0} \\
\frac{1}{1}\end{array}$} & Shale & 132 & V2-132 & 200.0 & 203.0 & 2.9 & 0.0 \\
\hline & & Shale w/streaks & 133 & V2-133 & 194.0 & 200.0 & 6.0 & 2.9 \\
\hline & & Shale w/nodules & 138 & $V 2-138$ & 181.0 & 194.0 & 13.0 & 8.9 \\
\hline \multirow{5}{*}{$\underset{\mathscr{N}}{\underline{\Sigma}}$} & \multirow{5}{*}{$\begin{array}{l}\propto \\
\frac{0}{0} \\
\frac{0}{1}\end{array}$} & Shale w/coal streaks & 136 & $R-136$ & 255.3 & 255.9 & 0.6 & 0.0 \\
\hline & & Shale w/nodules & 138 & $R-138 A$ & 250.7 & 255.3 & 4.6 & 0.6 \\
\hline & & Lost Core & - & - & 246.6 & 250.7 & 4.1 & 5.2 \\
\hline & & Shale w/nodules & 138 & $R-138 B$ & 243.3 & 246.6 & 3.3 & 9.3 \\
\hline & & Sandyshale w/streaks & 333 & $R-333$ & 234.0 & 243.3 & 9.3 & 12.6 \\
\hline
\end{tabular}




\section{CHAPTER 2: LITERATURE REVIEW}

As it can be understood from their name, weak rocks are the low strength rocks which cause problems for engineers. Their exact definition can hardly be made, so different authors used different limits and terms. The most common terms are weak rocks and soft rocks. However, indurated soils and low strength rocks are also used by some authors. Actually, weak is a relative concept but ISRM has defined weak rocks as rocks having uniaxial compressive strength between 290 psi and 2900 psi. Generally, scientists determine weak rocks by considering their deformability, uniaxial compressive strength, shear strength and time dependent behavior.

"How do the weak rocks behave?" has always been a question in scientists' and engineers' minds. For instance, time dependent behavior of weak rocks is so confusing because they may show creep even at low stress levels. This behavior is proved by many authors and accepted as a common property for weak rocks.

It is very hard to classify weak rocks since they are on the border between rocks and soils. Rocha [10] found that cohesion and uniaxial compressive strength are the best parameters that define the boundary between soil and rock. On the other hand, Oliveira [9] stated that when classifying weak rocks not only strength and cohesion of the rocks should be taken into consideration but also other properties have to be taken into account. The most used ones seemed to be the slaking and the swelling properties, since they exert a strong influence over the behavior of these materials in response to modifications in the moisture content or the state of stress. Slaking is basically related to the mineralogical arrangement of the components (texture). The propensity for swelling is controlled by the mineralogical composition of the rock, for example the presence of swelling clay minerals.

It is very useful to understand the reasons that make a rock weak while trying to understand their behavior and classifying them. Some materials are weak 
due to their principle components, and others may become weak as a result of progressive softening or weathering or alteration of the originally strong rocks. Oliveira [9] classified weak rocks based on their origin. Weak rocks may be weak as consequence of:

- poor bonding conditions of components

- weathering of components

- tectonisation (shearing due to folding and faulting)

- presence of cavities (voids and caverns)

Many authors have reported on correlations between some index properties and the mechanical behavior of the rock material. The most common correlation is the one that is between moisture absorption and strength. Hamrol stated that the higher the water absorption, the higher the degree of weathering and the lower the strength [9]. Also, there is a good correlation between porosity and strength. It is a well known fact that porosity of rocks is affected by weathering processes. Dobereiner [11] found that porosity and uniaxial compressive strength were inversely proportional to each other.

It is very difficult to obtain accurate engineering properties of weak rocks because it is hard to prepare samples and test them by following the engineering standards. Either rock mechanics or soil mechanics tests can be applied on these rocks. While applying these tests, it is sometimes very hard to get good results due to the lack of the sensitivity of the equipment because it is designed to be applicable to either rocks or soils, not in between.

Shales are the most common weak rocks that geotechnical engineers face while designing mines and underground structures. The term shale is the common name applied to fine-grained varieties of sedimentary rocks that formed from consolidation of clay, silt and mud. These rocks are commonly composed of mica, and clay minerals; however, the grains are so fine that the rock seems to have homogenous appearance and individual minerals cannot be identified without the aid of a microscope. The percentages of silt and clay can vary, but at least fifty percent of the material in shale is finer than fine sand. Shales are sufficiently consolidated and lithified so that they have some ability to maintain their structure even if 
subjected to weathering. Shale shows various degrees of fissility or breaking characteristics and different descriptive terms such as, blocky, platy, flaky and slabby have been used to describe fissility in shale. The origin of the rock from soil to shale is given in Figure 2.1 and from shale to metamorphic rock is given in Figure 2.2 .

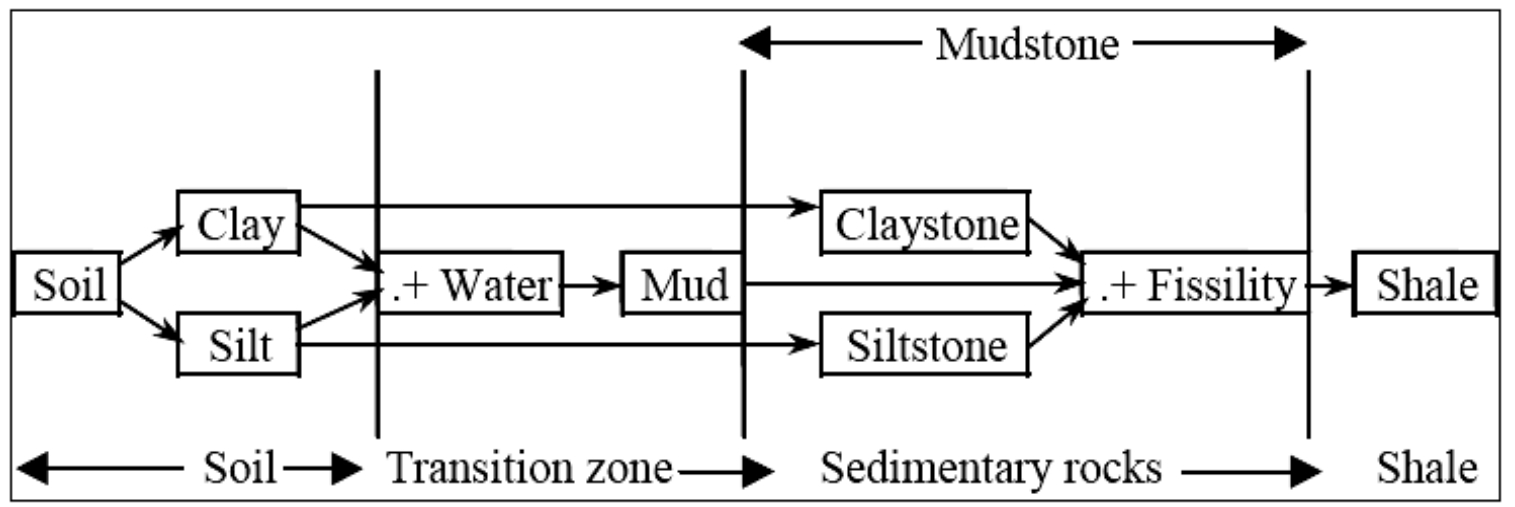

Figure 2.1: Shales and related sedimentary rocks [3]

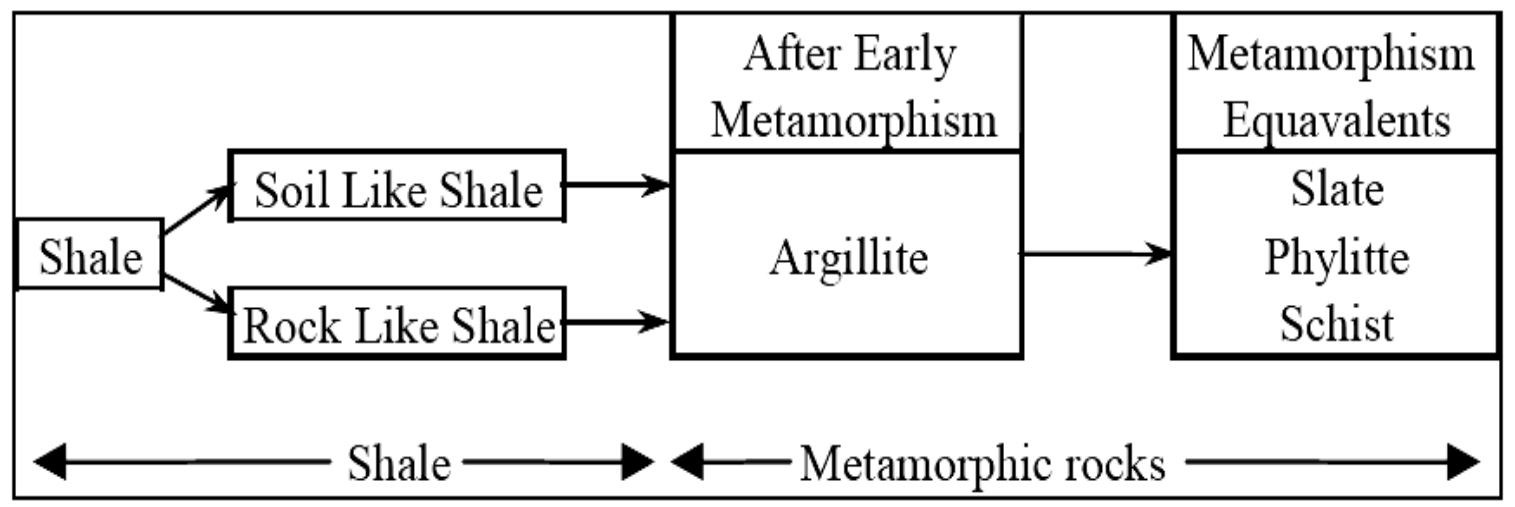

Figure 2.2: Shales and related metamorphic rocks [3]

Engineers and geologists propose various shale classification systems but there are considerably variations in the classification and evaluation of shale properties since each investigator has different objectives. Shales can be classified into two main groups [3], which are shown in Figure 2.3:

1) Compaction or "soil like" shales have been consolidated by the weight of overlying sediments and lack significant amounts of intergranular cement.

2) Cemented or "rock like" shales in which the cementing material may be calcareous, siliceous, gypsiferous, phosphatic etc. 


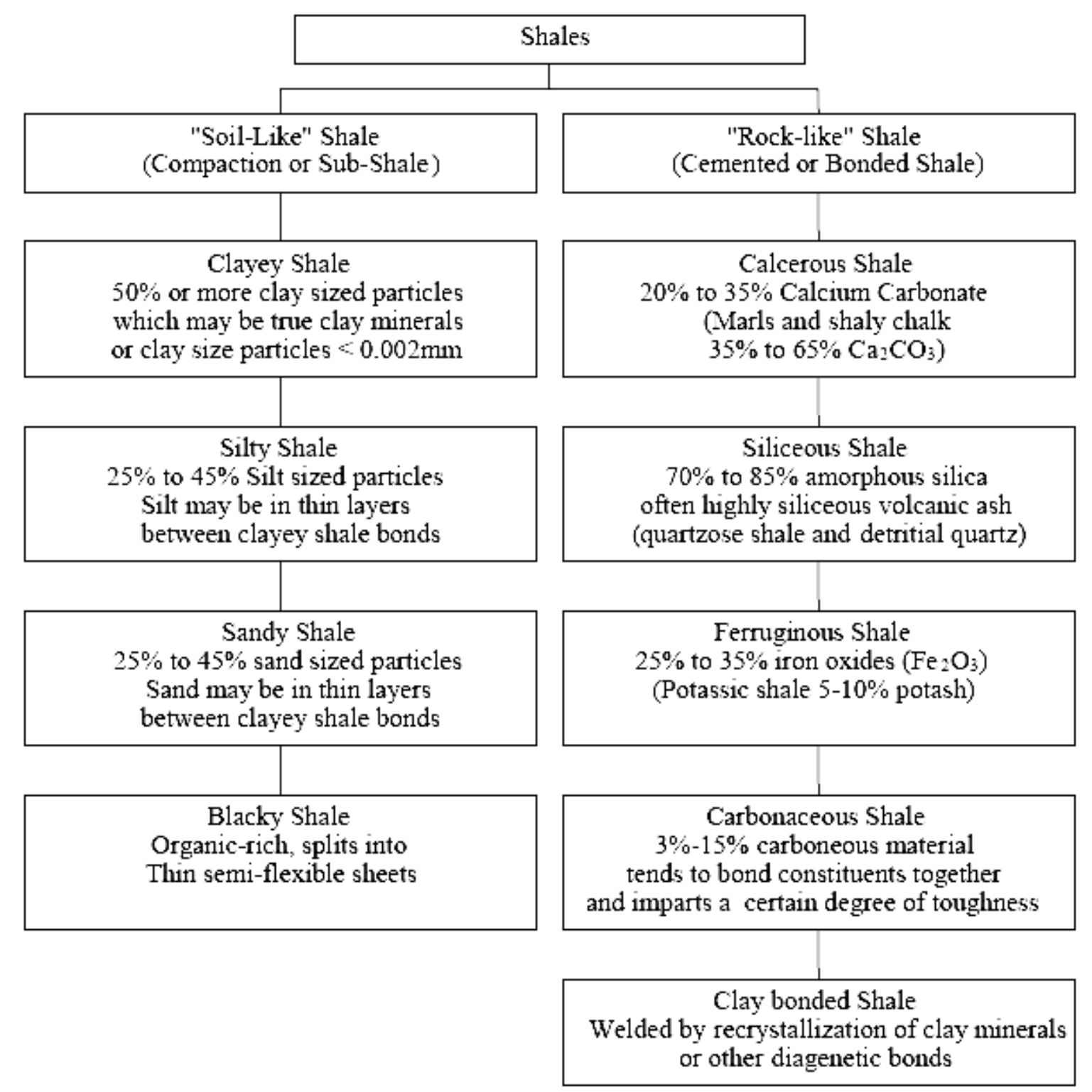

Figure 2.3: Classification and geological consideration of shales [3]

Weak shales refer to those with lower strength, thinly laminated structure, sensitive to moisture and weathering as well as significant time dependent behavior. It has been said that many future coal reserves with good quality have weak shale immediate roofs. Therefore, their geomechanical properties and behavior must be known before an appropriate support plan can be designed [12]. In order to achieve this goal, numerous attempts have been made by many researchers. They tried to estimate and correlate the properties of weak shales. 
For instance, many authors verified that the strength of the weak shales decreases with the increase of moisture content. Zhang et al., [12] also found that the low strength of weak shales is also correlated with low Young's modulus and low shear strength. They also stated that seasonal change of air humidity does have some weathering effect on weak shale. Also, Van Eeckhout and Peng [29] observed the increase in compliance (decrease in Young's Modulus and increase in Poison's Ratio) with increased moisture. They also concluded that the change in compliances from 0 to $48 \%$ humidity was much less marked than from 48 to $100 \%$ humidity. The compliance across the bedding plane at high humidity increased very rapidly compared to the compliance along the bedding plane. Aughenbaugh [21] also found that the strength of shale is inversely proportional with humidity as illustrated in Figure 2.4.

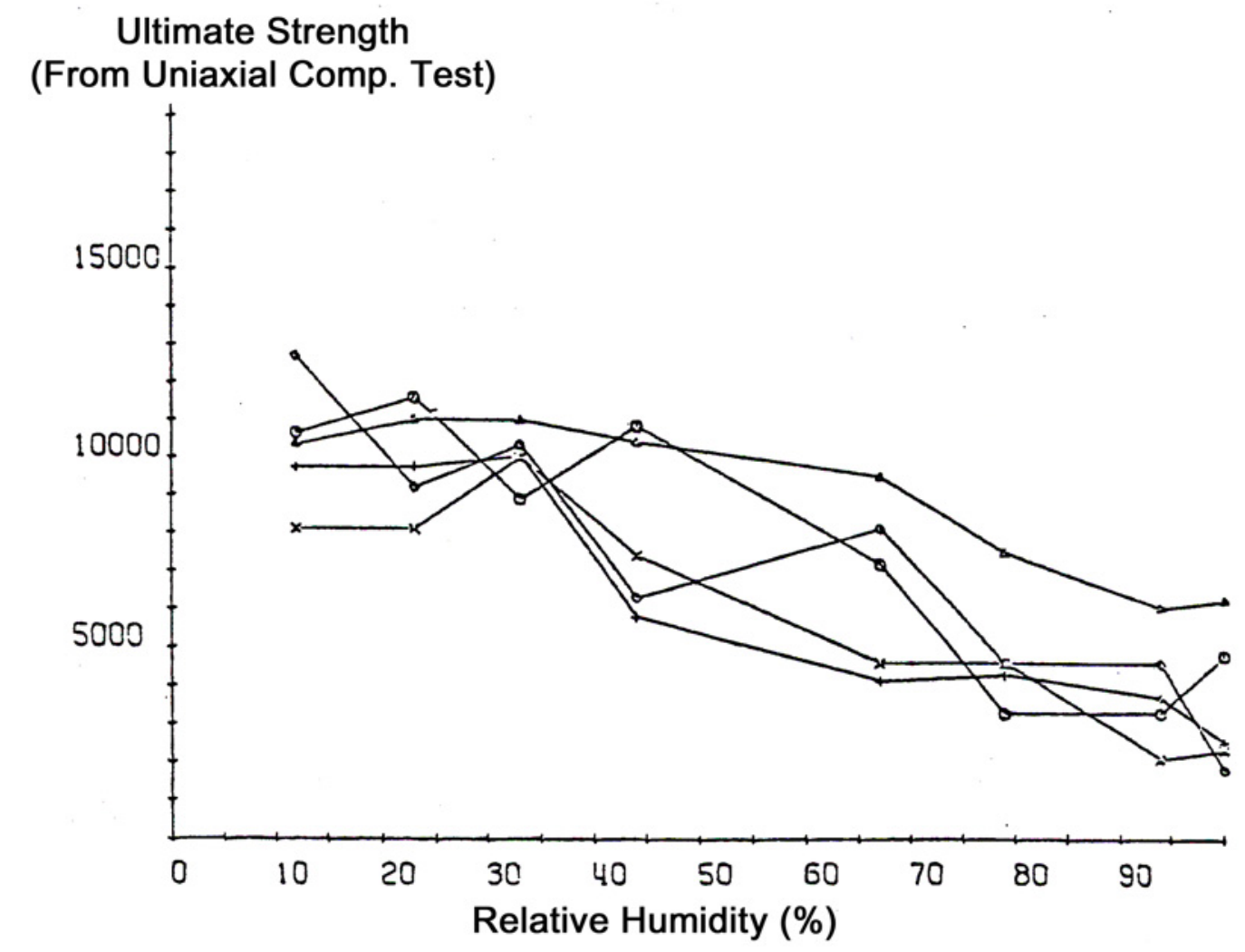

Figure 2.4: Decrease of the uniaxial compressive strength with increase of humidity [21]

Swelling is another important characteristic of shales, since these rock types can absorb moisture and swell. Holtz and Gibbs [16], and Meade [17] conducted a series of laboratory tests and found that shale exhibits a wide range of swelling 
potentials under soaking. Their result indicated that the volume expansion depends principally upon the fabric of particles and the existence of swelling clay minerals. Huang $[13,14]$ conducted some laboratory tests on the swelling of coal shales. He noted that the initial relative humidity of the air and the moisture susceptibility of shales are two important factors. Huang et al., [15] tried to analyze the factors that control swelling of shales. They considered moisture activity index (a measurement of moisture susceptibility of shale), relative humidity and testing temperature as the factors that affect swelling. They concluded that among the three factors they studied, the temperature of the shale had the least influence on swelling of shales, while the tempering of air humidity and the moisture activity index had a profound influence. Also, Huang et al., [14] found that shales, initially exposed in air with low relative humidity $(0-44 \%)$, have very similar swelling responses. The swelling was insignificant for materials with a low moisture activity index and minor for materials with a high moisture activity index [13].

Singh and Cummings [19] tested swelling of claystone, gray shale, and black shale and concluded that in a vertical (perpendicular to bedding) direction, claystone can swell as much as $7 \%$ (exceeds the levels required to fail a rock), while shales could only swell less than $2 \%$. However, lateral swelling is generally insignificant. They assumed that less than $3 \%$ of swelling strain can be tolerable, but they stated that a future study needs to be done in order to say something clearly about the tolerable strain value. This result showed rocks having more clay content expand much more than other rocks, it also proved vertical swelling is more significant than lateral swelling. A typical plot of strain perpendicular and parallel to the bedding plane as a function of time after immersing in water is given in Figure 2.5. Actually, scientists all agree that the amount of swelling is always greater in the perpendicular direction to the bedding planes than parallel to the bedding. Moreover, Cummings et al., [20] concluded from the shale testing that shale deterioration in mine roofs is not a slaking problem in the usual sense. Rather, it seems to be connected with stresses resulting from moisture-induced weakening and swelling.

Scientists have tried to explain the mechanism of swelling in rocks. The diffuse double layer theory was one of these explanations. It was adopted by Blackmore and Miller to describe the shale moisture interaction. As moisture migrates into shales, the previously absorbed cations tend to move out from the clay particles due to the concentration difference between the adsorbed water in the 
particle surface and the infiltrating water. Interaction between the clay-water system results in a difference in surface potential between the attractive force and the double layer repulsive force. The net balance of forces determines whether shale expands or not, a negative balance indicates a high potential for expansion [14]. Huang et al., [14] also claimed that shales with even trace amounts of clay minerals can generate a fair amount of expansive force. Also, even shale without smectite minerals (problem minerals that cause swelling) can have very significant swelling. This suggests that clay content and type of clay mineral are not the only factors influencing the expansion of shale. Other material properties such as particle arrangement, pressure release and other factors also affect the swelling behavior of shale.

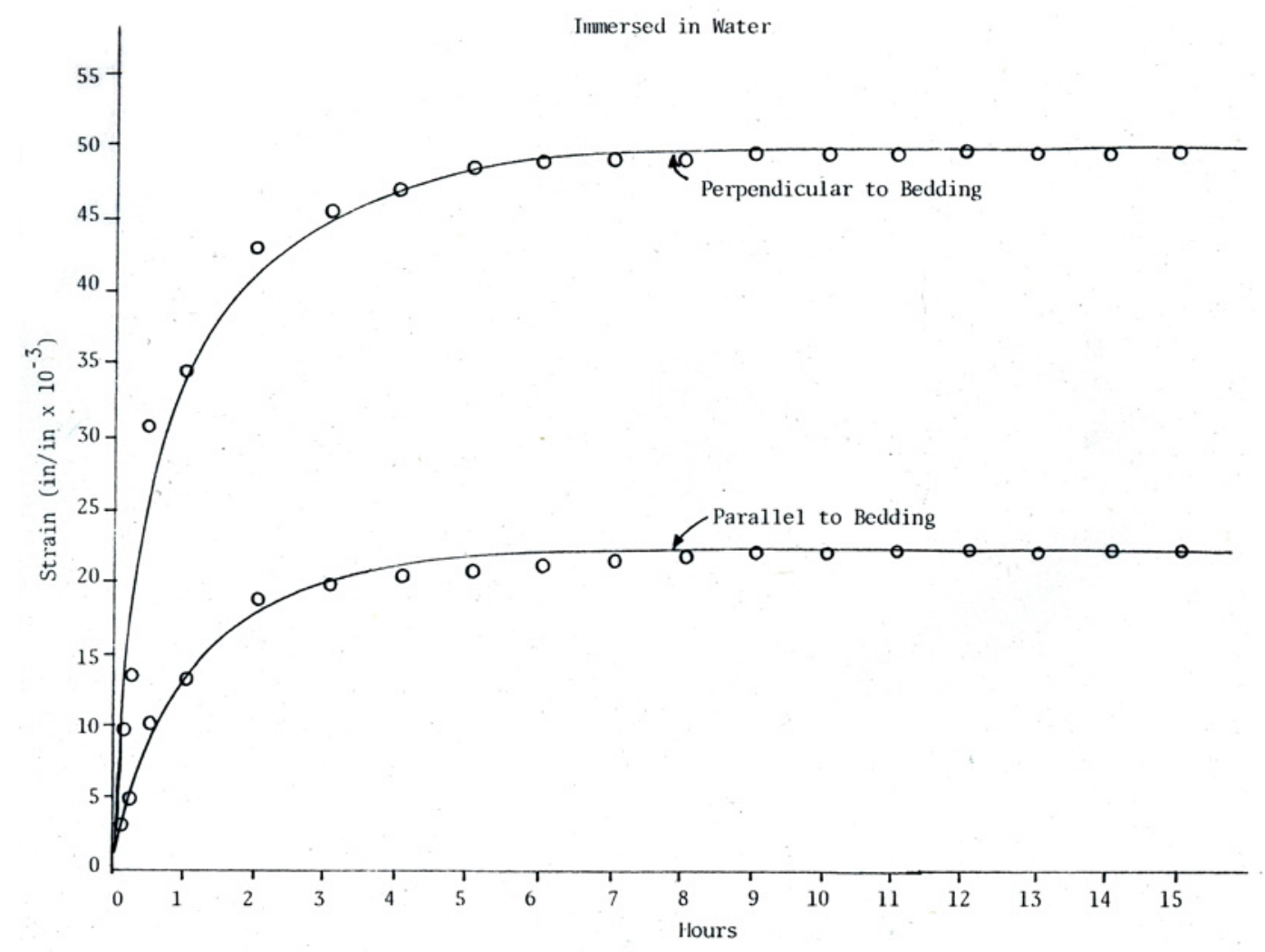

Figure 2.5: Unconfined swelling strains as a function of time for gray shale [30]

Mielenz and King [26] summarized the mechanisms of expansion as: (1) A relaxation of effective compressive stress related to enlargement of capillary films and (2) Osmotic imbibitions of water by expending lattice clays. In shrinkage, the same factors are active except the action is reversed. They also defined the 
mechanism of slaking as follows: (1) During drying, shales shrink and differential stresses are set up which cause cracks. (2) As the water evaporates from shales, it is replaced by air. (3) When water is reabsorbed by shales, the air is entrapped and compressed in capillary openings and causes tensile stresses. (4) Also, as shales adsorb water, particularly if they contain expanding clay minerals, differential stresses are created. (5) The stresses caused by entrapped air and expanding materials, if present, act to cause the clay to slake. On the other hand, Van Eeckhout [27] listed the mechanisms to describe the deterioration of weathered rocks as: (1) Chemical and corrosive deterioration (2) Pore pressure increase (3) Frictional reduction (4) Fracture energy reduction (5) Capillary tension increase.

In fact, shale is hydrophilic and attracts water, and because of that moisture can quickly penetrate along the bedding planes and fissures, affecting a considerable volume of rock. However, the permeability of intact shale is low, particularly in the direction perpendicular to bedding. It is well known in mining practice that shale strata can effectively isolate the water in the confined conditions of a rock mass. In the unconfined conditions, the shale which absorbs moisture will expand. The volume increase causes a reduction in density, an increase in porosity, and a loss of strength [21].

Furthermore, scientists proposed specific tests that are mainly applicable to weak rocks and especially shales. For example, the slake durability index test is the most common test that is performed to estimate the durability of shales. This test was introduced by Franklin in 1972 to estimate the susceptibility of rocks to deterioration by water submersion and mechanical agitation. However, some of the researchers do not agree with the standard test method to determine the slake durability index that is given in the standards of ASTM and ISRM. They rejected this test due to the inaccurate evaluation of rock durability. Hopkins and Deen [25] evaluated ten different slake durability test procedures. They found a good correlation between a newly devised slake durability index (the decay index, as proposed by the authors) and the water content of shales after swelling was completed. They also recommended the one 60 minute cycle with air-drying procedure for the identification of slake durability characteristics of shales. Instead of slake durability index, rock durability can also be estimated by the Duncan free swelling index and the geodurability index. Duncan [23] stated that rock failure will occur during saturation when the swelling stress, which develops in the rock as a 
result of capillary pressure, exceeds the tensile strength of the rock material. Furthermore, Olivier [24] improved Duncan's index and developed the geodurability classification.

Besides, Aughenbaugh [22] developed a test, called the moisture activity index test, to evaluate the reduction in durability and swelling due to moisture effects. The test was developed from laboratory humidity studies and incorporates chemical desiccation cabinets or environmental chambers. The test results are very useful for evaluating the shale behavior and this test is commonly used by many researchers in shale evaluation studies. Also, Unrug [21] introduced the weatherability test due to the need for a quantitative measure of the weathering potential of roof rock. This test imitates the natural process in a mine by subjecting the rock sample to alternating wet and dry cycles.

It has also been proven by many researchers that atmospheric air changes in temperature and humidity as it is drawn down the intake shaft and is circulated throughout the mine. They found direct relationships between the effects of moisture (such as weathering of rocks and roof falls) and high levels of humidity. For instance, generally mines having shale roofs have more ground control problems during the summer months. Moisture enters into the rock during the summer time, which can be considered as a wetting period. On the other hand, winter time can be considered as a drying period. These periods cause shale to swell. Due to swelling, cracks occur inside the rock and the rock gets weaker. Furthermore, moisture penetrates into these cracks and goes deep inside the rock and causes more severe situations. This means that roof rock can be weakened by the effect of moisture and cause ground control problems. A very good example of this situation is shown in Figure 2.6, which indicates a very close relationship between the humidity levels and roof falls throughout the years.

The moisture absorption characteristic of shales is very important because the more moisture the shale absorb, the more likely the rock will weaken. Aughenbaugh has conducted extensive research on this topic. One of his conclusions is that the rate of water absorption in shales is highest at the outset and decreases exponentially with time. After 5 to 6 days, over 80 percent of the total absorption will have taken place. For practical purposes the process will come to equilibrium in 10 to 20 days [22]. 

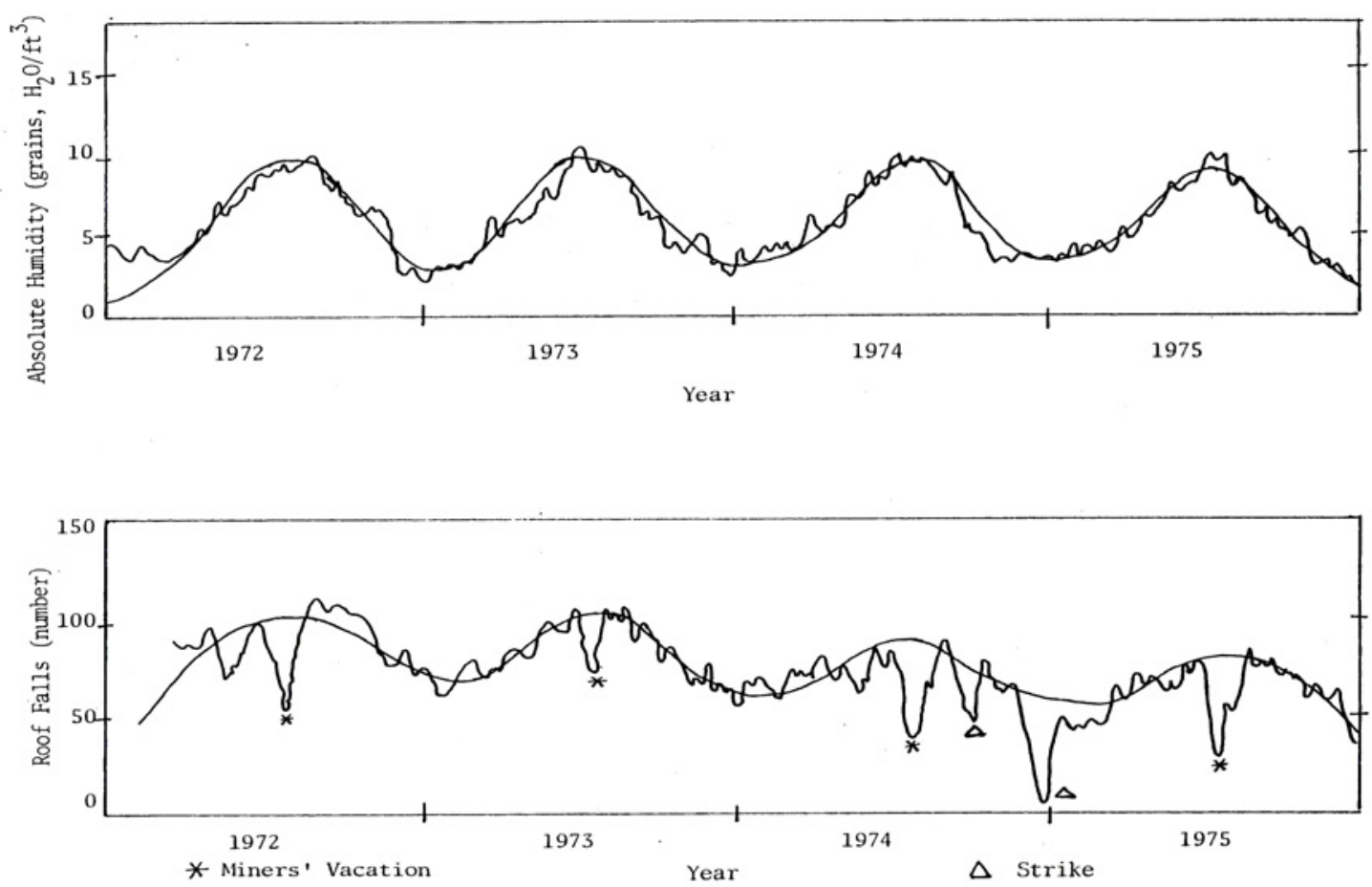

Figure 2.6: A comparison of total roof falls and absolute humidity [30]

Both field and laboratory studies indicated the depth to which moisture is absorbed by shale is very shallow if no discontinuities or defects exist or are generated. Various laboratory data establish the effective depth of penetration at less than a quarter of an inch. However, moisture can migrate rapidly and to great depths along discontinuities such as bedding planes, fractures and bolt holes. Aughenbaugh [22] also found that rocks with bedding perpendicular to the exposed face absorbed 50 percent more water than ones with the bedding parallel to the free surface.

Koncagul and Santi [32] observed that grain size, grain shape, and sometimes porosity have a contradictory effect on slake durability index and uniaxial compressive strength. These physical factors cause the slake durability index to increase and the uniaxial compressive strength to decrease or vice versa. Furthermore, they found that the Shore hardness is not affected by many of the geomechanical properties. In their research, they tried to predict the unconfined uniaxial compressive strength using slake durability, the Shore hardness and rock structural properties. 
Identification of the clay minerals inside the shales is very useful for understanding the shale behavior. It was proven that weak rocks, especially shales, consist of a mixture of various clay minerals and impurities. The clay content and percentages of clay mineral types are useful indicators of the plastic and swelling behavior. It is a very common conclusion of mineralogical analyses that specific clay minerals such as montmorillonite, vermiculite and smectite would cause problems, if they exist in the rock composition. 


\section{CHAPTER 3: \\ LABORATORY TESTS}

\subsection{Common Tests Performed on Shales}

In order to understand the behavior and mechanics of shales, researchers have introduced and performed many different tests as listed below:

- Moisture activity index - water absorption - relative humidity tests

- Density and porosity determination

- Point load strength index test

- Slake durability - Duncan free swelling - geodurability index tests

- Ultrasonic wave velocity test

- Schmidt hardness - Shore hardness index tests

- Weatherability index test

- Water content determination

- Jar slake index test

- Swelling strain - swelling stress tests

- Uniaxial and triaxial strength - direct shear strength - deformability tests

- Odeometer compressibility and consolidation tests

- Rod penetration test

- Chemical analysis - x-ray diffraction test - mineralogical analysis 


\subsection{Point Load Strength Index Test}

This test is an ASTM standard (Designation: D 5731 - 95) and named as "Standard Test Method for Determination of the Point Load Strength Index of Rock". Actually, it is an alternative to the uniaxial compression test to estimate the strength of rock. It is often used on non-standard core pieces.

The point load test was used in this research because it does not require extensive sample preparation techniques and it is easy to apply. As it was mentioned in the previous chapter, shales are very sensitive to water and it is almost impossible to apply the sample preparation procedures that are required by the standard uniaxial compression test. Besides, it was very hard to find NX size samples from the available core boxes because during transportation of these boxes from the drill site to the laboratories, most of the shale samples were broken down or affected by moisture. The point load strength values were only used to classify the shale types and were not used in any engineering design. Therefore, the point load test was applicable for this research.

Point load strength index is an indicator of strength obtained by subjecting a rock specimen to an increasingly concentrated point load, applied though a pair of truncated, conical platens, until failure occurs [33]. There are three types of standard point load tests, which are called: the diametral test, the axial test, and the block and irregular lump tests. According to the dimensions of the available samples, axial and diametral point load tests, illustrated in Figure 3.1, were applied.

Axial Test

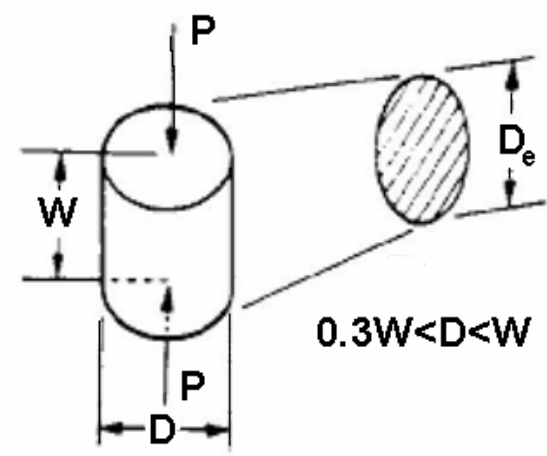

Diametral Test

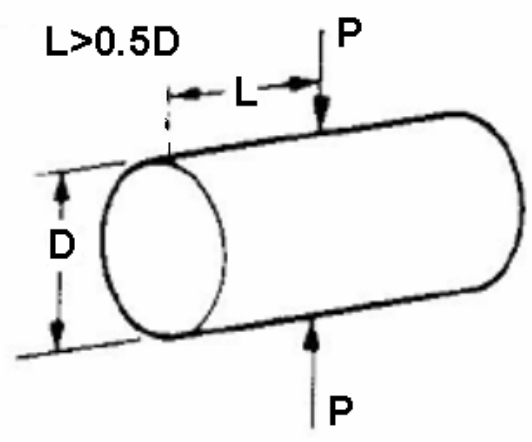

Figure 3.1: Axial and diametral point load tests 
The apparatus (Figure 3.2) of the test consist of a rigid frame, two point load platens, a hydraulic ram including a pressure gage to read the peak applied pressure and a device for measuring the distance between the loading points.

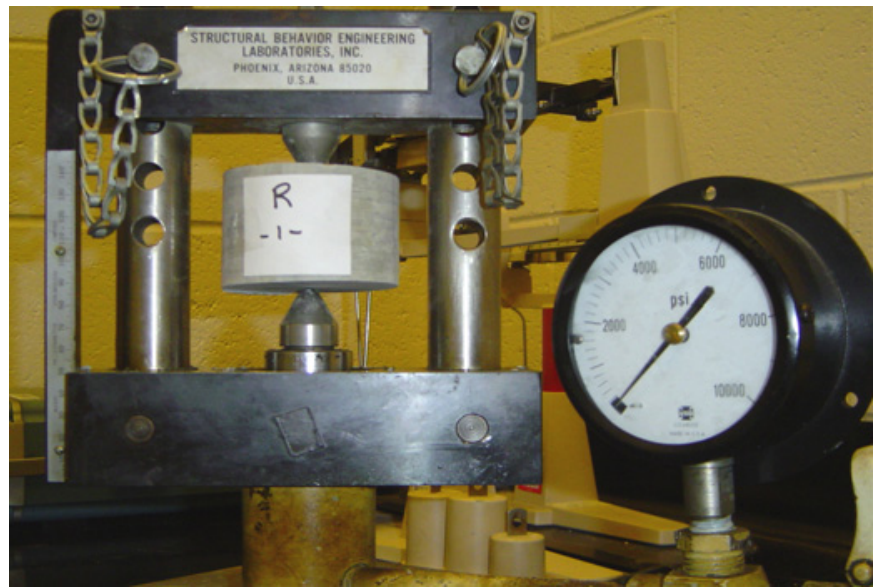

Figure 3.2: Point load test apparatus

\subsubsection{Calculations}

The uncorrected point load strength index $\left(I_{s}\right)$ is calculated as:

$$
I_{s}=\frac{P}{D_{e}^{2}}(\mathrm{psi})
$$

where $P$ is the failure load (Ibs), $D_{e}$ is the equivalent core diameter (in).

$$
D_{e}=D \text { for the diametral test and } D_{e}=\sqrt{\frac{4 A}{\pi}} \text { for the axial test (in) ... }
$$

where $A=W D$, is the minimum cross-sectional area $\left(i n^{2}\right)$ shown in Figure 3.1. The size-corrected point load strength index, $I_{s(50)}$, is calculated as:

$$
I_{s(50)}=F \times I_{s}(\mathrm{psi})
$$

where $F$ is the size correction factor and it is calculated as ( $F=1$ for $2^{\prime \prime}$ core):

$$
F=\left(\frac{25.4 \times D_{e}}{50}\right)^{0.45}
$$


Finally, the estimated uniaxial compressive strength, $\delta_{u c}$, is calculated as:

$$
\delta_{u c}=C \times I_{s(50)}(\mathrm{psi})
$$

where $\mathrm{C}$ is a factor that depends on the site-specific correlation between $\delta_{u c}$ and $I_{s(50)}$. Some studies have been done to find the best and most accurate value for this factor. According to Rusnak and Mark [34], a conversion factor C=21 worked well for a variety of rock types and geographic regions. Therefore, this $C$ factor was taken as 21 in this study.

\subsection{Slake Durability I ndex Test}

This test is also an ASTM standard (Designation: D 4644 - 87) and named as "Standard Test Method for Slake Durability of Shales and Similar Weak Rocks". This test was introduced by Franklin to estimate the susceptibility of rocks to deterioration by water submersion and mechanical agitation. The slake durability index is the percentage by dry mass retained of a collection of shale pieces on a $2.00 \mathrm{~mm}$ (No. 10) sieve after two cycles of oven drying and 10 min of soaking in water with a standard tumbling and abrasion action [35]. A higher slake durability index indicates higher durability of the shale sample. In this study, it was expected that this test would be beneficial to compare the durability of different shale types.

Ten representative shale fragments weighing 40 - $60 \mathrm{~g}$ each were selected. Almost no sample preparation steps were involved in this test. The fragments may be naturally occurring or obtained from breaking with a hammer. A slake durability set-up shown in Figure 3.3 was used to run this test.

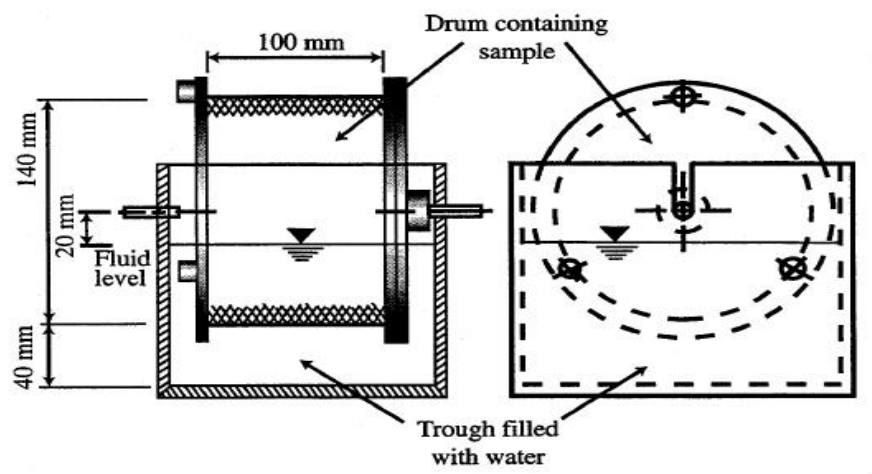

Figure 3.3: Critical dimensions of slake durability equipment [35] 


\subsubsection{Testing Procedure and Calculations}

1) Calculate the natural water content, $w(\%)$, as in Equation 3-6 by drying the samples in the oven for $16 \mathrm{~h}$ at $110 \pm 5^{\circ} \mathrm{C}$ and weighing them.

$$
w=\left[\frac{A-B}{B-C}\right] \times 100
$$

where $A$ is the mass of drum plus the sample at natural moisture content $(\mathrm{g}), B$ is the mass of drum plus the oven-dried sample before the first cycle $(\mathrm{g})$ and $\mathrm{C}$ is the mass of drum $(\mathrm{g})$.

2) Fill the trough with distilled water as shown in Figure 3.3 and rotate the drum at $20 \mathrm{rpm}$ for $10 \mathrm{~min}$.

3) Remove the drum from the trough immediately after the rotation period is completed and dry the drum and the sample in the oven for $16 \mathrm{~h}$.

4) Weigh the drum and sample and calculate the slake durability index for the first cycle, $I_{d(1)}$, by using Equation 3-7.

5) Repeat the steps 2 to 4 to calculate the slake durability index for the second cycle, $I_{d(2)}$, by using Equation 3-8.

$$
\begin{aligned}
& I_{d(1)}=\left[\frac{W_{1}-B}{B-C}\right] \times 100 \\
& I_{d(2)}=\left[\frac{W_{2}-B}{B-C}\right] \times 100
\end{aligned}
$$

where $W_{1}$ and $W_{2}$ are the mass of drum plus oven-dried sample retained after the first and second cycles, respectively. 


\subsection{Moisture Activity I ndex Test}

Aughenbaugh [22] proposed the moisture activity index test from his field investigations and laboratory studies to explain the shale durability as it relates to humidity conditions. The moisture activity index test is also known as the relative humidity test. The test was developed from laboratory humidity studies and incorporates chemical desiccation cabinets or environmental chambers. The data generated by the test give an index number that has been correlated with the in situ behavior of shale. A higher moisture activity index indicates higher water absorption of the shale sample. Scientists accepted that the greater the percent weight gain of rocks at a given relative humidity, the greater is their moisture sensitivity. Hence, this test helps us to identify the moisture sensitive rocks. Although the test is time consuming, it is simple to perform.

The testing apparatus only consist of a humidity chamber system that includes humidifying and dehumidifying units, a controller, and a chamber as shown in Figure 3.4.

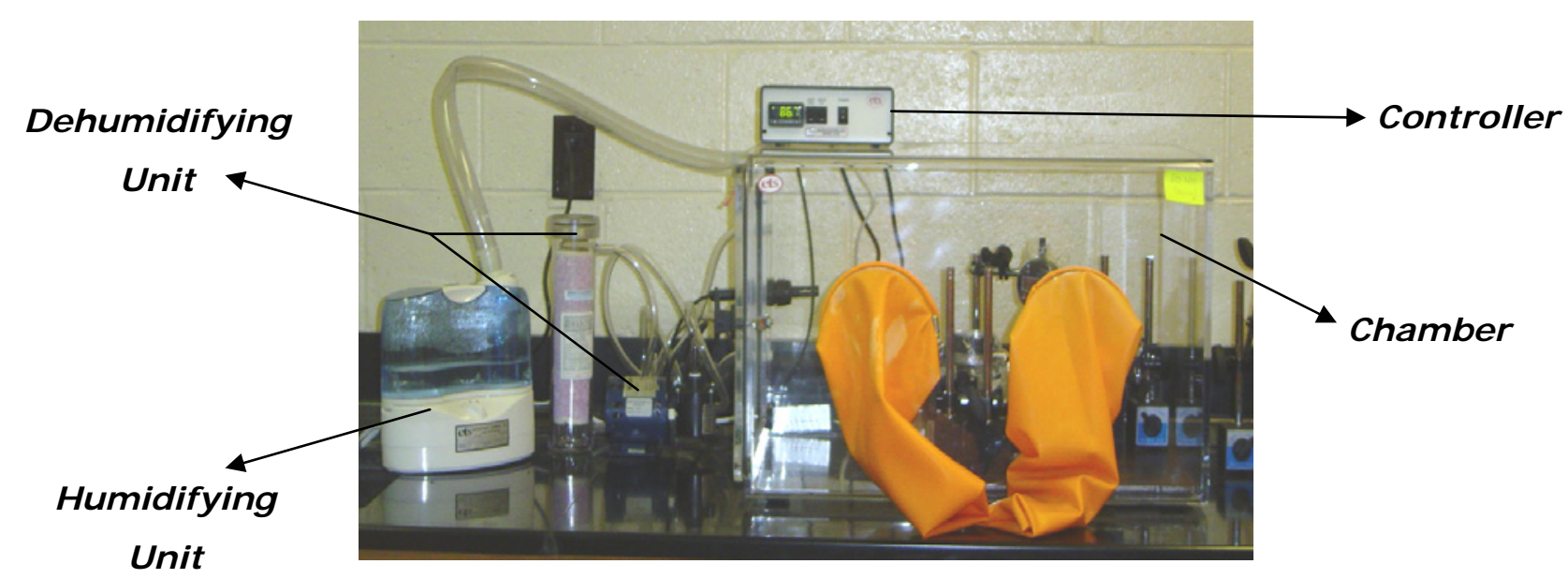

Figure 3.4: The humidity chamber used in this study

\subsubsection{Testing Procedure and Calculations}

1) Oven dry the samples for $16 \mathrm{~h}$ at $110 \pm 5^{\circ} \mathrm{C}$.

2) Weigh the samples and place them inside a humidity chamber at a relative humidity ranging between $0 \%$ and $100 \%$. In this study, the relative humidity values were selected as $20 \%, 50 \%, 80 \%$ and $100 \% \mathrm{RH}$. 
3) Weigh the samples each day and if no more change is observed in the weight of the specimen, increase the relative humidity level and repeat this step to the end of $100 \% \mathrm{RH}$. It took $6,11,14$ and 20 days for the selected rocks to be stabilized in weight at $20 \%, 50 \%, 80 \%$ and $100 \%$ $\mathrm{RH}$, respectively.

4) Calculate the percent weight change (or water content) at the specific relative humidity as follows:

Weight Change $(\%)=\frac{\text { Final Specimen Weight }- \text { Dry Specimen Weight }}{\text { Dry Specimen Weight }} \times 100(3-9)$

5) Calculate the moisture activity index $\left(I_{R H}\right)$ as follows:

$I_{R H}=\%$ Weight Change @ 100\% RH - \%Weight Change @ 20\% RH .... (3-10)

An example of the calculation of the moisture activity index test is given in Figure 3.5.

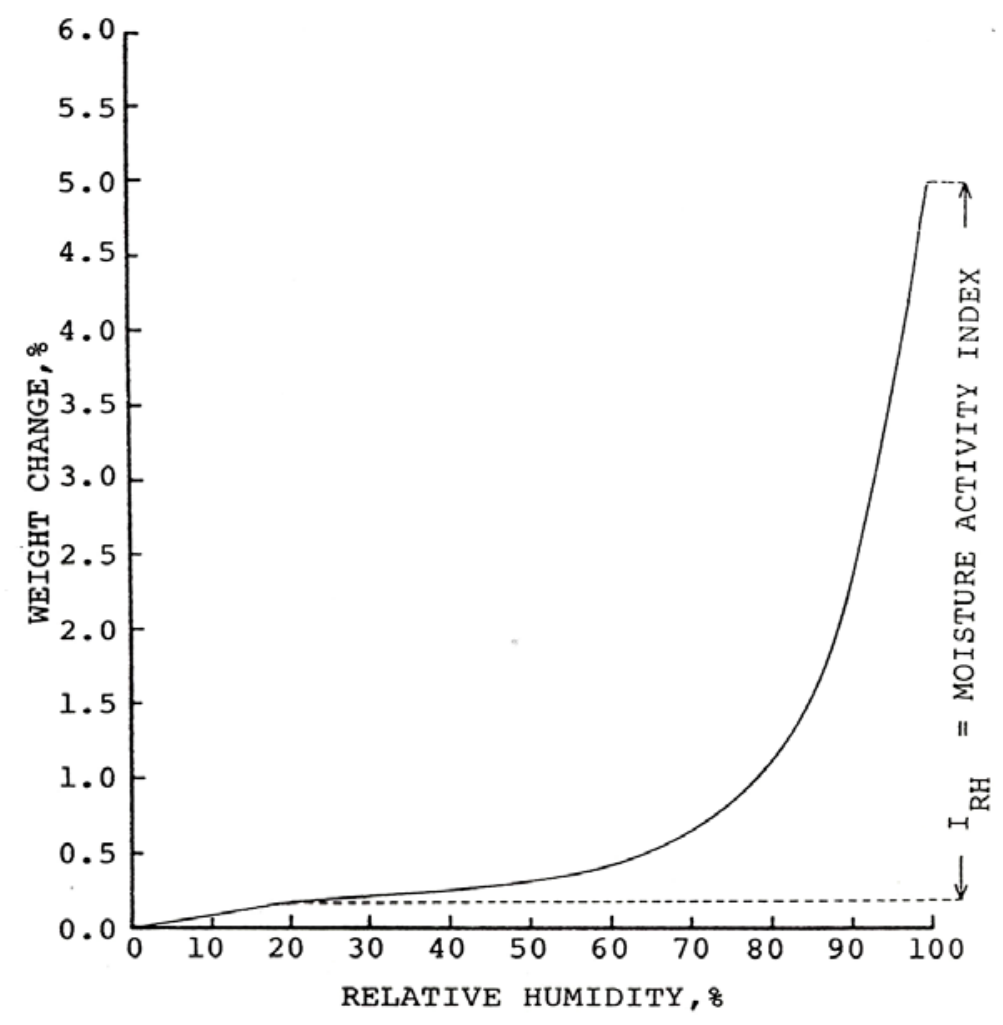

Figure 3.5: Moisture activity index term [22]. 


\subsubsection{Classification}

Aughenbaugh [22] classified shales having $I_{R H}$ :

1) Less than 1 , as stable rocks.

2) Between 1 and 4, as mildly susceptible to humidity changes. From the long term standpoint, they may show progressive deterioration especially if the relative humidity cycles between low and high percentages.

3) Between 4 and 7, as moisture sensitive rocks. These shales will deteriorate and become unstable when exposed to a humid atmosphere. In mines and tunnels they will cause ground control problems if not sealed or supported.

4) Greater than or equal to 7, as non-durable rocks. These shales are the rocks that rapidly slake to mud when immersed in water.

\subsection{Water (Moisture) Content Determination Test}

This test is also an ASTM standard (Designation: D 2216 - 98) and named as "Standard Test Method for Laboratory Determination of Water (Moisture) Content of Soil and Rock Mass". Water content of a material is the ratio expressed as a percent mass of "pore" or "free" water in a given mass of a material to the mass of the solid material. Water content is one of the most significant index properties used in establishing a correlation between soil and rock behavior and their index properties [37].

The main apparatus of this test consist of an oven that is capable of maintaining $110 \pm 5^{\circ} \mathrm{C}$ and a balance that is capable of reading $0.01 \mathrm{~g}$.

\subsubsection{Testing Procedure and Calculations}

1) Record the original weight of the specimens.

2) Placed them in an oven. 
3) Dry the specimens to a constant mass at $110 \pm 5^{\circ} \mathrm{C}$ unless otherwise specified. The time required to obtain the constant mass will vary depending on the type of the material, size of the specimen, oven type and capacity and other factors. In this study, 16 hours was selected as the required time to dry the shale samples to a constant mass.

4) Record the weigh of the dry specimens.

5) Calculate the water content of the material, $w(\%)$, as follows:

$$
w=\frac{\left(M_{w}-M_{d}\right)}{M_{d}} \times 100
$$

where $M_{w}$ is the mass of wet specimen ( $\mathrm{g}$ ) and $M_{d}$ is the mass of the dry specimen $(\mathrm{g}) . M_{w}-M_{d}$ is the mass of water inside the material.

\subsection{Weatherability I ndex Test}

The weatherability test for rocks in underground mines was introduced by Unrug [21] to estimate the weathering properties of rocks by the help of an index number obtained at the end of the test. This test is very useful and easy because it is suitable for testing cores samples as well as irregular samples, specimen preparation is not required and the testing procedure is very simple. This test simulates weathering cycles in mines at accelerated time. The weatherability index from this test is used to compare the characteristics of different types of shales and understand the weathering properties of them. A higher weatherability index indicates higher weatherability and lower durability of the rock sample.

The testing apparatus should be built as illustrated in Figure 3.6. It is not possible to purchase the entire apparatus since this is not a standard test and the exact equipment is not directly available on the market. However, it is inexpensive and simple to build. The major part is a tank in which a grill with a screen is affixed and on which the samples are placed. The water level in the tank is adjusted by a float-controlled valve, which cuts off the water supply when water covers the samples. Another drain valve is controlled by a timer (activated after 1 hour). The water drains down, lowering the level below the grill. Another position of the float, 
through the action of electric relay, cuts off the drain valve when water in the tank reaches the prescribed low level. In a side chamber of the tank, a room fan is affixed with plastic wire ties in a horizontal position. This fan is controlled by a timer switch and switches on when water stops draining.

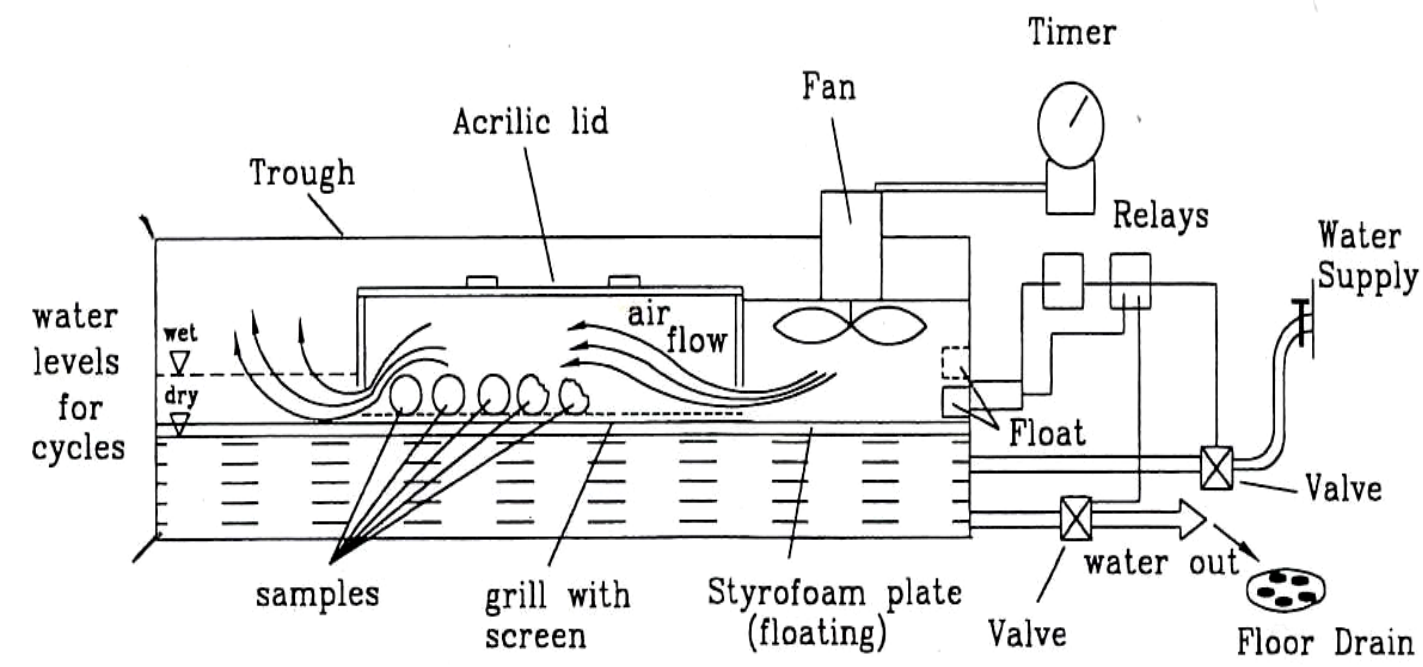

Figure 3.6: Schematic of the weatherability test apparatus [21].

The weatherability test apparatus, shown in Figure 3.7, were built and used in the laboratories of the National Institute for Occupational Safety and Health (NIOSH), Pittsburgh Research Laboratory (PRL).
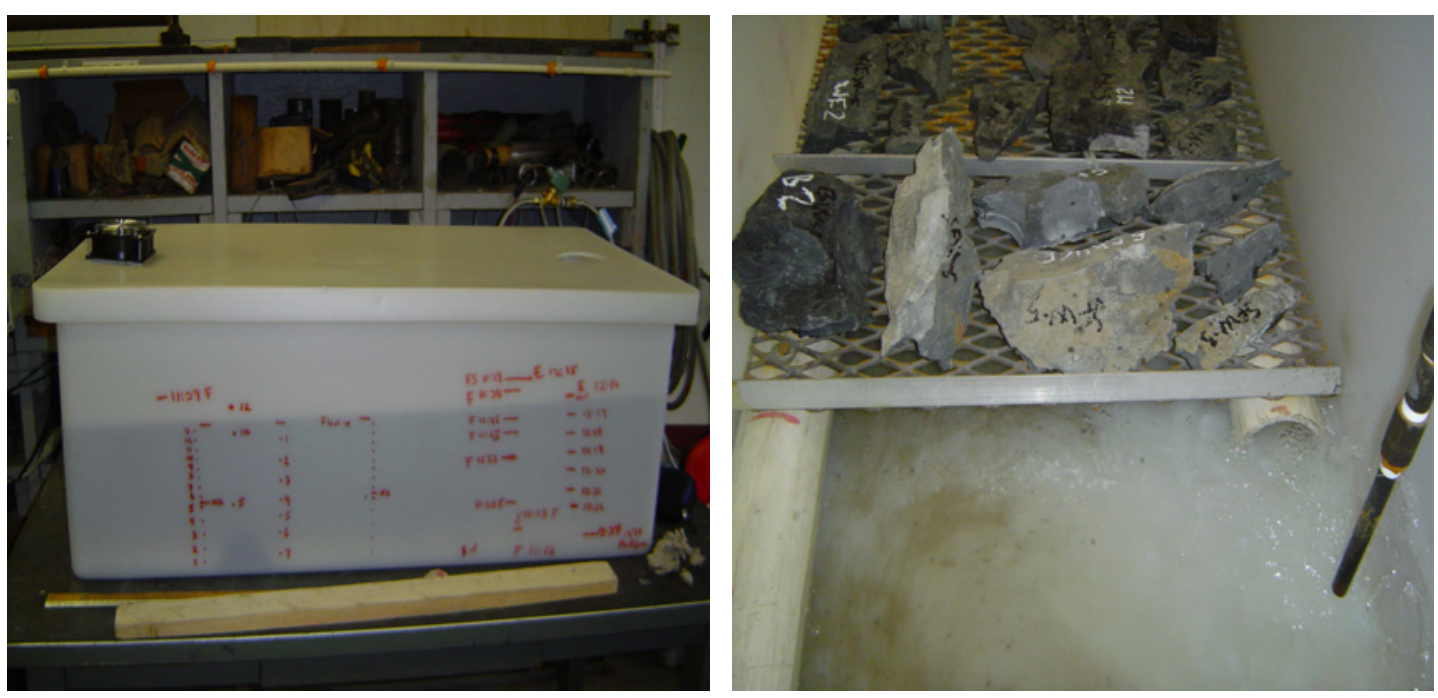

Figure 3.7: The weatherability test apparatus. 


\subsubsection{Testing Procedure and Calculations}

1) Oven dry the samples for $16 \mathrm{~h}$ at $110 \pm 5^{\circ} \mathrm{C}$.

2) Weigh and put them inside the tank, number them and take photographs.

3) Soak with water for 1 hour (wet cycle).

4) Dry for 6 hours by running the installed fan (dry cycle). Dry and wet cycles start and run automatically with the help of the timer and the installed electronic setup.

5) Repeat the steps 3 and 4 and check the samples and decide how many more cycles should be run before terminating the test. For this study, it was decided to run three cycles.

6) Terminate the test and take photographs of the samples for comparison.

7) Pick up the largest elements of the samples surviving the test and dry them in the oven for 16 hours at $110 \pm 5^{\circ} \mathrm{C}$.

8) Calculate the weatherability index, WAI (\%), as:

$W A I=\frac{W_{i n i}-W_{\text {rem }}}{W_{i n i}} \times 100$

where $W_{i n i}$ is the initial weight of the sample $(\mathrm{g})$ and $W_{\text {rem }}$ is the weight of the remaining fragment of a sample $(\mathrm{g})$.

\subsection{Swelling Strain Test}

This test is originally described by ISRM as a rock characterization test and named as "Suggested Method for Determination of the Swelling Strain Developed in an Unconfined Rock Specimen" [38]. The standard test was modified for using in this research. Actually, this test measures the swelling strain of rock samples in water. However, in this research, different relative humidity levels were used instead of water (assumed $100 \% \mathrm{RH}$ ) to determine the swelling behavior of shales in various humidities. The unconfined swelling strain test should only be applied to specimens 
that do not change their geometry appreciably on slaking. This means that less durable rocks are better tested using a confined test.

The testing apparatus are shown in Figure 3.8 and are listed as follows:

- A humidity chamber that is capable of maintaining relative humidities between $20 \%$ and $100 \%$.

- A set of micrometer dial indicators that are capable of reading to $0.0005 \mathrm{in}$.

- A set of magnetic base indicator holders to stabilize the indicators.

- A steel plate to activate the magnetic force supplied by the holders.
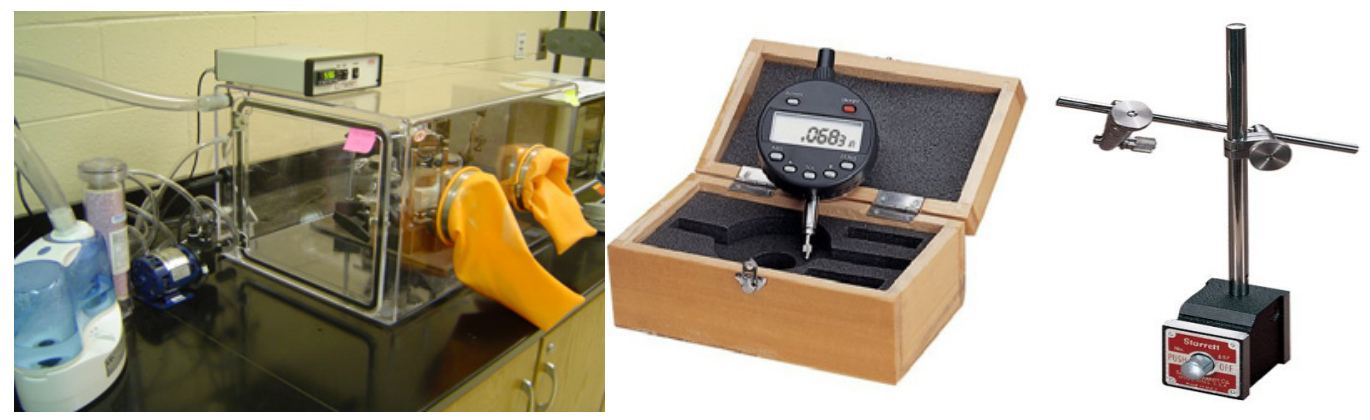

Figure 3.8: The swelling strain test apparatus; humidity chamber (including steel plate), dial indicator and magnetic holder

\subsubsection{Testing Procedure and Calculations}

1) Place the specimen inside a humidity chamber.

2) Employ dial indicators as shown in Figure 3.9 (such that laminations are in the horizontal direction) to measure strains either in vertical or lateral directions.

3) Maintain the desired humidity levels. In this study, $20 \%, 50 \%, 80 \%$, and $100 \%$ RH levels were used.

4) Record the displacement each day until no more change is observed.

5) Increase the humidity to the next level and continue recording. 
6) Stop at the end of $100 \% \mathrm{RH}$ and calculate the unconfined swelling strain, $\varepsilon_{X}(\%)$, as:

$$
\varepsilon_{X}=\frac{d}{L} \times 100
$$

where $x$ is a direction relative to the bedding or foliation, $d$ is the maximum swelling displacement recorded in the direction $x$ (in) and $L$ is the initial length in the direction $x$ (in).

7) Also, calculate the volumetric strain, $\varepsilon_{\text {vol }}(\%)$, as in Equation $3-14$, if it is applicable.

$$
\varepsilon_{v o l}=\frac{\Delta V}{V} \times 100
$$

where $\Delta V$ is the change in volume $\left(\mathrm{in}^{3}\right)$ and $V$ is the initial volume of the specimen $\left(\mathrm{in}^{3}\right)$.

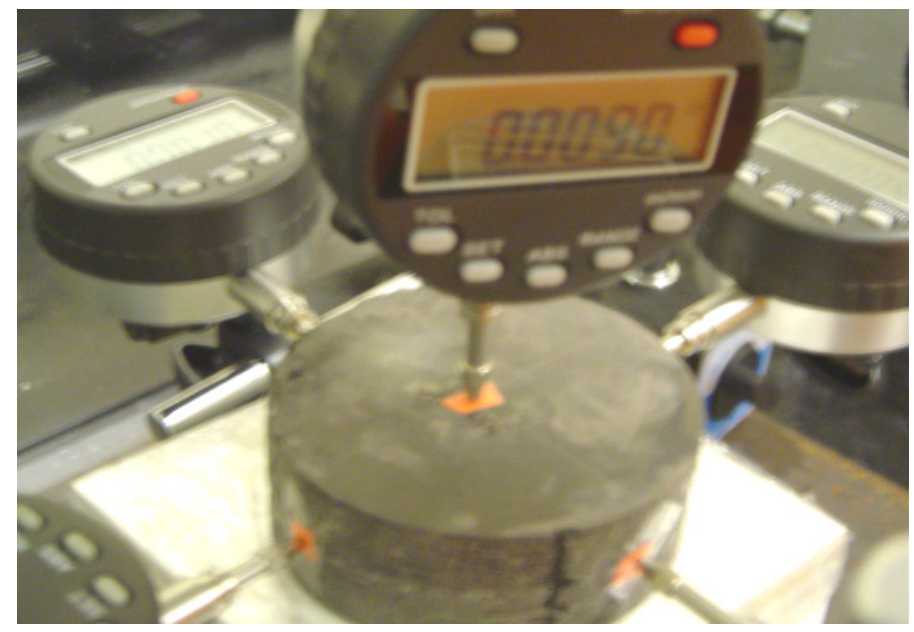

Figure 3.9: The unconfined swelling strain test setup

\subsection{X-ray Diffraction Test}

The x-ray diffraction technique is used for identification and interpretation of clay minerals and non-clay minerals in a rock specimen. When a prepared specimen slide is clamped in place, the $\mathrm{x}$-ray diffraction instrument rotates the slide in the path of a collimated $x$-ray beam. At the same time, an x-ray detector tube mounted on an 
arm of the diffractometer, rotates to pick up the diffracted $x$-ray signals. In the zerodegree position, the $\mathrm{x}$-ray beam is parallel to the slide and passes directly into the $\mathrm{x}$ ray detector. The slide and the counter are driven by a motor through separate gear trains so that while the specimen slide rotates through the angle $\theta$, the detector rotates through angle $2 \theta$. During the scanning operation the specimen slide, $\mathrm{x}$-ray detector and paper drive of the strip chart recorder are set in motion simultaneously. According to Bragg's equation:

$$
n \lambda=2 d \sin \theta
$$

where $\mathrm{n}$ equals to $1,2,3$, etc, which are known as first, second, third-order, etc, reflections, $\lambda$ is the monochromatic radiation wavelength (armstrongs), $d$ is the interplanar spacing of the mineral layer (armstrongs) and $\theta$ is the angle between incident and diffracted $\mathrm{x}$-ray beams which is detected through the detector counter (degrees).

If an atomic plane (of the mineral layer) has an interplanar spacing (d), such that a reflection occurs at angle $\theta=4$ degrees, there is no evidence of this reflection until the detector counting tube has been rotated through angle $2 \theta$, or 8 degrees. At this point the diffracted beams enter the $x$-ray detector causing it to respond. The generated pulses are subsequently amplified and cause a deflection on the recording pen on the strip chart. While the $x$-ray detector scans, the strip chart records the diffraction peaks or maxima from the specimen. The angle $2 \theta$ at which the diffraction occurred may be read directly from the position of the peak on the strip chart. The heights of the peaks are directly proportional to the scale factor that is set for the peak intensities [39].

In this research, the $x$-ray diffraction analysis was done for the determination of the mineralogy, especially clay mineralogy, of the shale samples. This analysis was done with the help of the Department of Chemical Engineering at West Virginia University. Rock powders were prepared from the available core samples and sent to the laboratories. Unfortunately, only few samples could be analyzed. 


\section{CHAPTER 4: \\ RESULTS \& DISCUSSION}

\subsection{Point Load Strength I ndex Test}

In total, 93 axial and 37 diametral point load tests were performed to estimate the strength of various shale types found in the roofs of Mine $\mathrm{V}$ and Mine $\mathrm{R}$. The entire test data are given in Appendix A. A summary of the point load tests including the estimated uniaxial compressive strength is given in Table 4.1.

Table 4.1. Summary of the point load test results

\begin{tabular}{|c|c|c|c|c|c|c|c|c|}
\hline \multirow[b]{2}{*}{ Mine } & \multirow[b]{2}{*}{ Hole } & \multirow[b]{2}{*}{$\begin{array}{l}\text { Rock } \\
\text { Code }\end{array}$} & \multicolumn{3}{|c|}{ Axial Point Load Test } & \multicolumn{3}{|c|}{ Diametral Point Load Test } \\
\hline & & & $\begin{array}{c}\text { Average } \\
\text { UCS } \\
\text { (psi) } \\
\end{array}$ & \begin{tabular}{|c}
$\begin{array}{c}\text { Standard } \\
\text { Deviation } \\
\text { (psi) }\end{array}$ \\
\end{tabular} & \begin{tabular}{|c|}
$\begin{array}{c}\text { Number } \\
\text { of } \\
\text { Test }\end{array}$ \\
\end{tabular} & \begin{tabular}{|c|} 
Average \\
UCS \\
(psi) \\
\end{tabular} & \begin{tabular}{|c}
$\begin{array}{c}\text { Standard } \\
\text { Deviation } \\
\text { (psi) }\end{array}$ \\
\end{tabular} & \begin{tabular}{|c|c|}
$\begin{array}{c}\text { Number } \\
\text { of } \\
\text { Test }\end{array}$ \\
\end{tabular} \\
\hline \multirow{11}{*}{$\begin{array}{l}> \\
\stackrel{0}{\Sigma} \\
\stackrel{\Sigma}{\Sigma}\end{array}$} & \multirow{8}{*}{$\begin{array}{l}-1 \\
\frac{1}{0} \\
\frac{0}{x}\end{array}$} & $\mathrm{~V} 1-110 \mathrm{~A}$ & 1,348 & - & 1 & - & - & - \\
\hline & & $V 1-132 A$ & 1,685 & 62 & 2 & - & - & - \\
\hline & & $\mathrm{V} 1-110 \mathrm{~B}$ & 1,526 & - & 1 & - & - & - \\
\hline & & $\mathrm{V} 1-132 \mathrm{~B}$ & 1,704 & - & 1 & - & - & - \\
\hline & & $\mathrm{V} 1-338$ & 2,162 & 975 & 9 & - & - & - \\
\hline & & V1-133 & 2,194 & 1,694 & 3 & - & - & - \\
\hline & & $\mathrm{V} 1-138$ & 3,826 & 1,060 & 10 & 661 & 349 & 7 \\
\hline & & V1-333 & 4,752 & 1,129 & 12 & 827 & 183 & 5 \\
\hline & \multirow{3}{*}{$\begin{array}{l}\mathbf{N} \\
\frac{0}{0} \\
\stackrel{0}{1}\end{array}$} & V2-132 & 2,254 & 1,137 & 9 & 301 & 283 & 2 \\
\hline & & V2-133 & 2,767 & 1,872 & 9 & 1,215 & 1,869 & 4 \\
\hline & & V2-138 & 5,052 & 937 & 12 & 1,394 & 677 & 6 \\
\hline \multirow{4}{*}{$\begin{array}{l}\stackrel{\boldsymbol{\alpha}}{\boldsymbol{v}} \\
\stackrel{\underline{\Sigma}}{\boldsymbol{\Sigma}}\end{array}$} & \multirow{4}{*}{$\begin{array}{l}\alpha \\
\frac{\alpha}{0} \\
\frac{0}{x}\end{array}$} & $R-136$ & 2,323 & 789 & 2 & 200 & 141 & 2 \\
\hline & & $\mathrm{R}-138 \mathrm{~A}$ & 2,978 & 539 & 6 & 773 & 35 & 2 \\
\hline & & R-138B & 3,587 & 712 & 7 & 299 & 209 & 5 \\
\hline & & $R-333$ & 4,947 & 1,547 & 9 & 823 & 155 & 4 \\
\hline
\end{tabular}


The diametral point load test sometimes cannot be applied to the available core samples because most of the rocks in the core boxes have already been broken down into small pieces that are not adequate for the standards of this test, or they have very low strength in diametral loading. For example, 110 and 132 Ferm Number rocks have very thinly laminated structures and the diametral point load test is not applicable to these types of shales due to their extremely low strength in diametral loading. Also, axial point load tests could hardly be applied to the immediate roof of Hole V1 since there are few available core samples and the rocks are very weak.

According to the axial strength data, the shale types can be classified as shown below. As it was mentioned before, according to ISRM, rocks having uniaxial compressive strength less than 2,900 psi are classified as weak rocks. Also, in order to make a comparison between the shale types, the author defined subgroups (similar to Brown [42]) and named them as slightly weak rocks (uniaxial compressive strength is between 2,900 and 3,900 psi) and medium strong rocks (uniaxial compressive strength is between 3,900 to 7,250 psi). So, the classification is as follows:

- V1-110A, V1-132A, V1-110B, V1-132B, V1-338 and V1-133, V2-132 and V2-133, and R-136 are weak rocks

- V1-138, and R-138A and R-138B are slightly weak rocks

- V1-133, V2-138, and R-333 are medium strong rocks

It is clear that rocks from Hole V1 have very low strength and the strength values of the rocks from Holes $\mathrm{V} 2$ and $\mathrm{R}$ are similar to each other. The previous study about these mines also indicated that some parts of Mine $\mathrm{V}$ have extremely weak roof and other parts have better immediate roof conditions similar to Mine $\mathrm{R}$. Thus, the results of the strength test agree with the previous study. Rocks having Ferm Numbers of 110,132, 338, 133 and 136 have very weak strengths and therefore, they can be considered as problem materials for engineers. Moreover, the diametral point load strength data show that there is a significant difference between the axial and diametral strengths of all shales. The reason for that is the occurrence of bedding planes in these strata. 


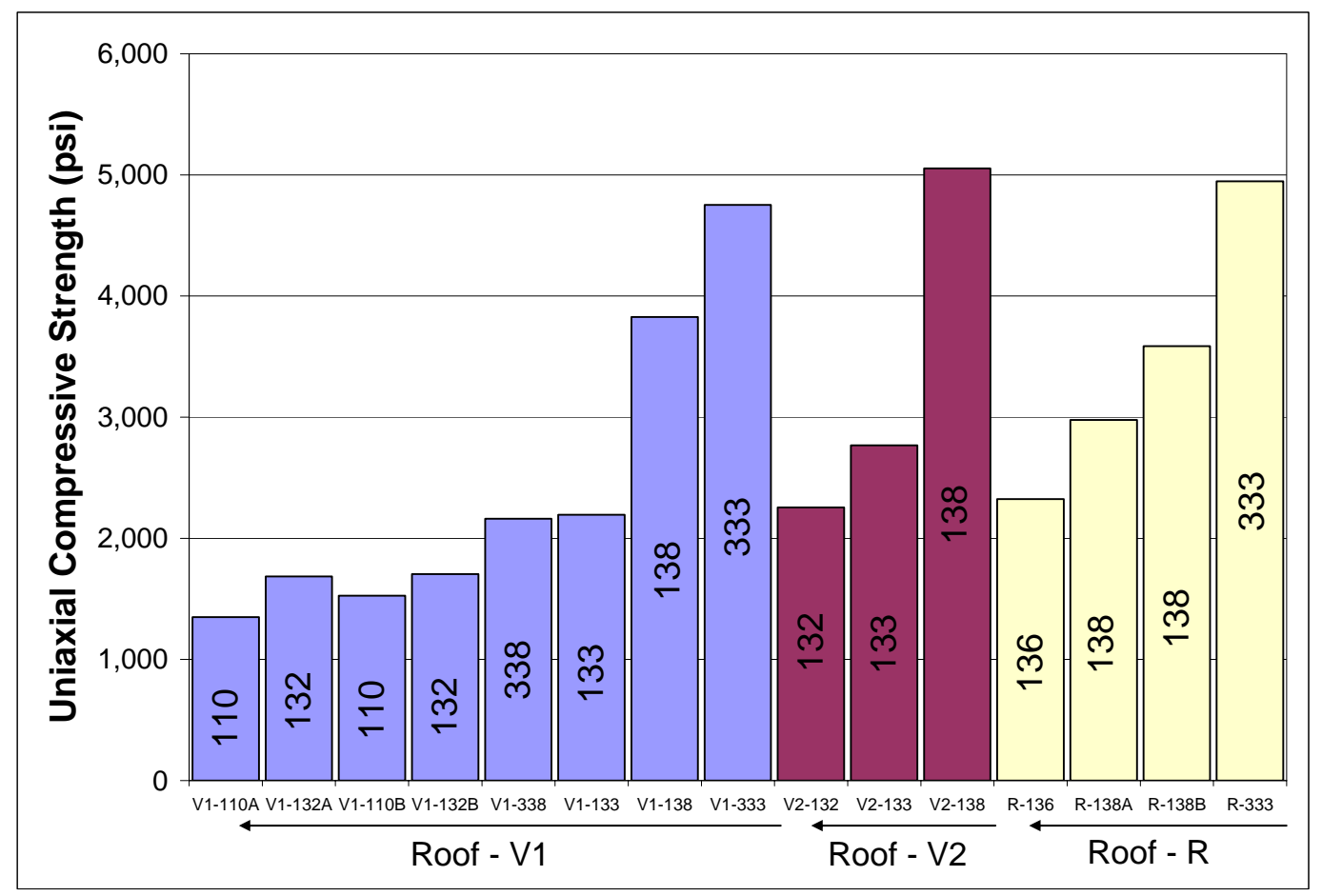

Figure 4.1: Axial point load test

The axial point load strength results are also summarized in Figure 4.1. Blue, red and yellow colors indicate the drill holes named as V1, V2 and R, respectively and the vertical numbers indicate Ferm Numbers. The arrows indicate the direction from the main roof to the immediate roof. It is clearly observed from Figure 4.1 that the rock strength increases with distance into the main roof in each drill hole. Therefore, the weak shales exist at the immediate roofs and stronger strata exist at the main roofs of these mines. Besides, the immediate roofs (0-6 ft) and main roofs (6-26 ft) of these mines were also individually analyzed and the strength values are shown in Tables 4.2 and 4.3. The significant difference between the diametral and axial point load results can also be seen from the tables.

Table 4.2. Immediate roof strengths

\begin{tabular}{|c|c|c|c|c|c|c|c|}
\hline \multirow{3}{*}{ Mine } & \multirow{2}{*}{ Hole } & \multicolumn{6}{|c|}{ Immediate Roof (0-6 ft) } \\
\cline { 3 - 8 } & & \multicolumn{4}{|c|}{ Axial Point Load Test } & \multicolumn{2}{c|}{ Diametral Point Load Test } \\
\cline { 2 - 8 } & $\begin{array}{c}\text { Average } \\
\text { UCS } \\
\text { (psi) }\end{array}$ & $\begin{array}{c}\text { Standard } \\
\text { Deviation } \\
\text { (psi) }\end{array}$ & $\begin{array}{c}\text { Number } \\
\text { of } \\
\text { Test }\end{array}$ & $\begin{array}{c}\text { Average } \\
\text { UCS } \\
\text { (psi) }\end{array}$ & $\begin{array}{c}\text { Standard } \\
\text { Deviation } \\
\text { (psi) }\end{array}$ & $\begin{array}{c}\text { Number } \\
\text { of } \\
\text { Test }\end{array}$ \\
\hline Mine V & Hole V1 & 1,637 & 576 & 8 & - & - & - \\
\hline Mine V & Hole V2 & 2,254 & 1,137 & 9 & 301 & 283 & 2 \\
\hline Mine R & Hole R & 2,814 & 623 & 8 & 486 & 342 & 4 \\
\hline
\end{tabular}


Table 4.3. Main roof strengths

\begin{tabular}{|c|c|c|c|c|c|c|c|}
\hline \multirow{2}{*}{ Mine } & \multirow{2}{*}{ Hole } & \multicolumn{6}{|c|}{ Main Roof (6-26 ft) } \\
\cline { 3 - 8 } & & $\begin{array}{c}\text { Average } \\
\text { UCS } \\
\text { (psi) }\end{array}$ & $\begin{array}{c}\text { Standard } \\
\text { Deviation } \\
\text { (psi) }\end{array}$ & $\begin{array}{c}\text { Number } \\
\text { of } \\
\text { Test }\end{array}$ & $\begin{array}{c}\text { Average } \\
\text { UCS } \\
\text { (psi) }\end{array}$ & $\begin{array}{c}\text { Standard } \\
\text { Deviation } \\
\text { (psi) }\end{array}$ & $\begin{array}{c}\text { Number } \\
\text { of } \\
\text { Test }\end{array}$ \\
\hline Mine V & Hole V1 & 3,617 & 1,432 & 29 & 730 & 293 & 12 \\
\hline Mine V & Hole V2 & 4,073 & 1,797 & 21 & 1,323 & 1,195 & 10 \\
\hline Mine R & Hole R & 4,352 & 1,402 & 16 & 532 & 327 & 9 \\
\hline
\end{tabular}

Statistical analyses were done to compare the strengths (axial point load strengths) of the immediate and main roofs for each hole and they are given in Appendix $A$. When the immediate roofs of these mines are taken into consideration, Mine $\mathrm{V}$ has a weaker immediate roof than Mine $\mathrm{R}$. Although some parts of Mine $\mathrm{V}$ have extremely weak immediate roof, moderately weak roof conditions, similar to Mine $R$, might also be seen in this mine. It can be said with more than $95 \%$ confidence that the immediate roof rocks from Hole V1 are weaker than the immediate roof rocks from Hole $R$. On the hand, the confidence intervals for the other two comparisons (Holes V1 vs. V2 and Holes V2 vs. R) are below 95\%. It was concluded that the immediate roof rocks from Hole V1 are slightly weaker than the immediate rocks from Hole V2, but the difference between the immediate roof rock strengths of Holes $\mathrm{V} 2$ and $\mathrm{R}$ is insignificant (less than $80 \%$ confidence level). Furthermore, Mine $\mathrm{V}$ has a slightly weaker main roof than Mine $\mathrm{R}$. The confidence intervals for all of the comparisons of the main roof strengths are lower than $\% 95$. Therefore, the differences between the main roof strengths are not significant. However, it can be said with $89.5 \%$ confidence that the main roof rocks from Hole V1 are weaker than the main roof rocks from Hole R.

\subsection{Slake Durability I ndex Test}

The detailed test results of the slake durability test are shown in Appendix B and the summary of this test is given in Table 4.4 and Figures 4.2 and 4.3. Again, blue, red and yellow colors indicate Holes V1, V2 and R, respectively and the vertical numbers indicate Ferm Numbers, and the arrows indicate the direction from the main roof to the immediate roof. 
Table 4.4. Slake durability test results

\begin{tabular}{|c|c|c|c|c|c|}
\hline Mine & Hole & $\begin{array}{l}\text { Rock } \\
\text { Code }\end{array}$ & $\begin{array}{c}\text { Water } \\
\text { Content } \\
(\%)\end{array}$ & $\begin{array}{c}\text { Slake } \\
\text { Durability } \\
\text { Index for } \\
\mathbf{1}^{\text {st }} \text { Cycle } \\
I_{d(1)}\end{array}$ & $\begin{array}{c}\text { Slake } \\
\text { Durability } \\
\text { Index for } \\
\mathbf{2}^{\mathbf{n e}} \text { Cycle } \\
I_{d(2)}\end{array}$ \\
\hline \multirow{11}{*}{$\begin{array}{l}> \\
\mathbf{0} \\
\underline{\Sigma}\end{array}$} & \multirow{8}{*}{$\begin{array}{l}-1 \\
\frac{0}{0} \\
\frac{1}{1}\end{array}$} & $\mathrm{~V} 1-110 \mathrm{~A}$ & 6.96 & 89.66 & 84.98 \\
\hline & & $\mathrm{V} 1-132 \mathrm{~A}$ & 2.44 & 90.16 & 75.79 \\
\hline & & V1-110B & 5.64 & 97.82 & 91.19 \\
\hline & & V1-132B & 3.62 & 72.93 & 55.69 \\
\hline & & V1-338 & 3.30 & 88.97 & 74.24 \\
\hline & & V1-133 & 4.07 & 89.81 & 76.51 \\
\hline & & V1-138 & 1.66 & 96.39 & 91.20 \\
\hline & & V1-333 & 0.77 & 96.46 & 92.28 \\
\hline & \multirow{3}{*}{$\begin{array}{l}N \\
\stackrel{N}{0} \\
\frac{0}{1}\end{array}$} & V2-132 & 2.33 & 76.53 & 53.80 \\
\hline & & V2-133 & 2.06 & 87.14 & 66.10 \\
\hline & & V2-138 & 1.30 & 96.24 & 92.19 \\
\hline \multirow{4}{*}{$\begin{array}{l}\underline{\alpha} \\
\stackrel{\mathscr{v}}{\Sigma} \\
\underline{\Sigma}\end{array}$} & \multirow{4}{*}{$\begin{array}{l}\propto \\
\frac{\alpha}{0} \\
\frac{0}{I}\end{array}$} & $R-136$ & 3.55 & 91.98 & 76.38 \\
\hline & & $R-138 A$ & 4.28 & 91.26 & 77.55 \\
\hline & & $R-138 B$ & 3.74 & 94.94 & 88.70 \\
\hline & & $R-333$ & 0.82 & 94.06 & 84.45 \\
\hline
\end{tabular}

The durability of $\mathrm{V} 1-132 \mathrm{~B}$ and $\mathrm{V} 2-132$ seems to be different than the rest of the shale types. Rocks having Ferm Numbers of 132 (except for V1-132A) have very low slake durability indices both in the first and second cycles. 133 Ferm Number rocks also seem to have moderately low indices. The durability difference of the rocks can be easily seen after the second cycle. The second cycle indices show that 110,138 and 333 are more durable rocks than the other ones. 110 especially show a higher resistance to the durability cycles compared to the other immediate roof shales. This indicates that carbonaceous shales have high durability despite their weakness in strength. It is hard to classify the rest of the rock types due to the close results.

Furthermore, the slake durability indices of roof rocks of Mine $\mathrm{R}$ are always greater than 75 and they have a higher durability than the roof rocks of Mine $\mathrm{V}$. The slake durability indices (second cycle) for V1-132B, V2-132 and R-136 are 55.69, 
53.80 and 76.38, respectively. It is observed that the immediate roof rocks at Mine $R$ have higher durability than the one (except for 110) at Mine V.

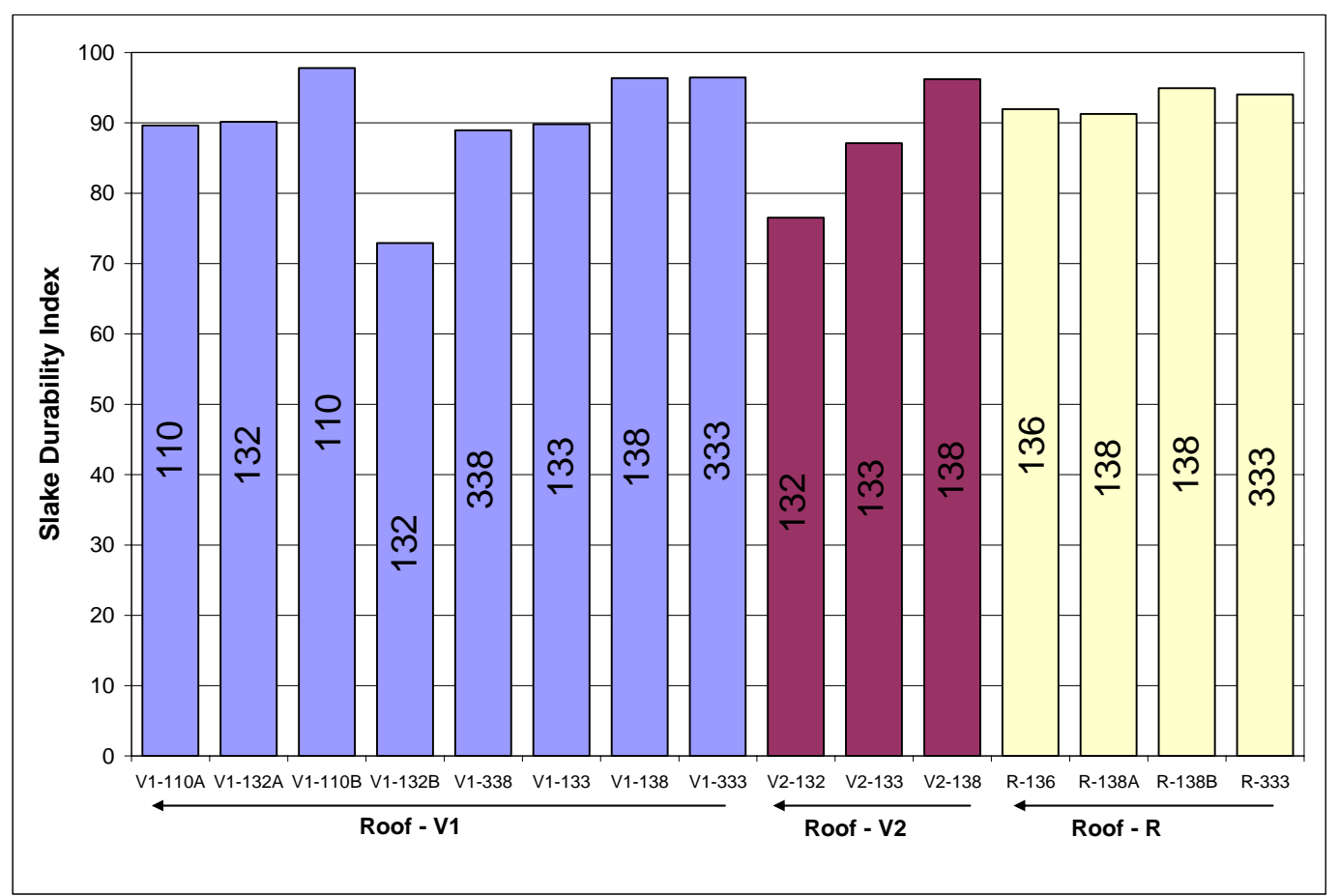

Figure 4.2: Slake durability indices for first cycle

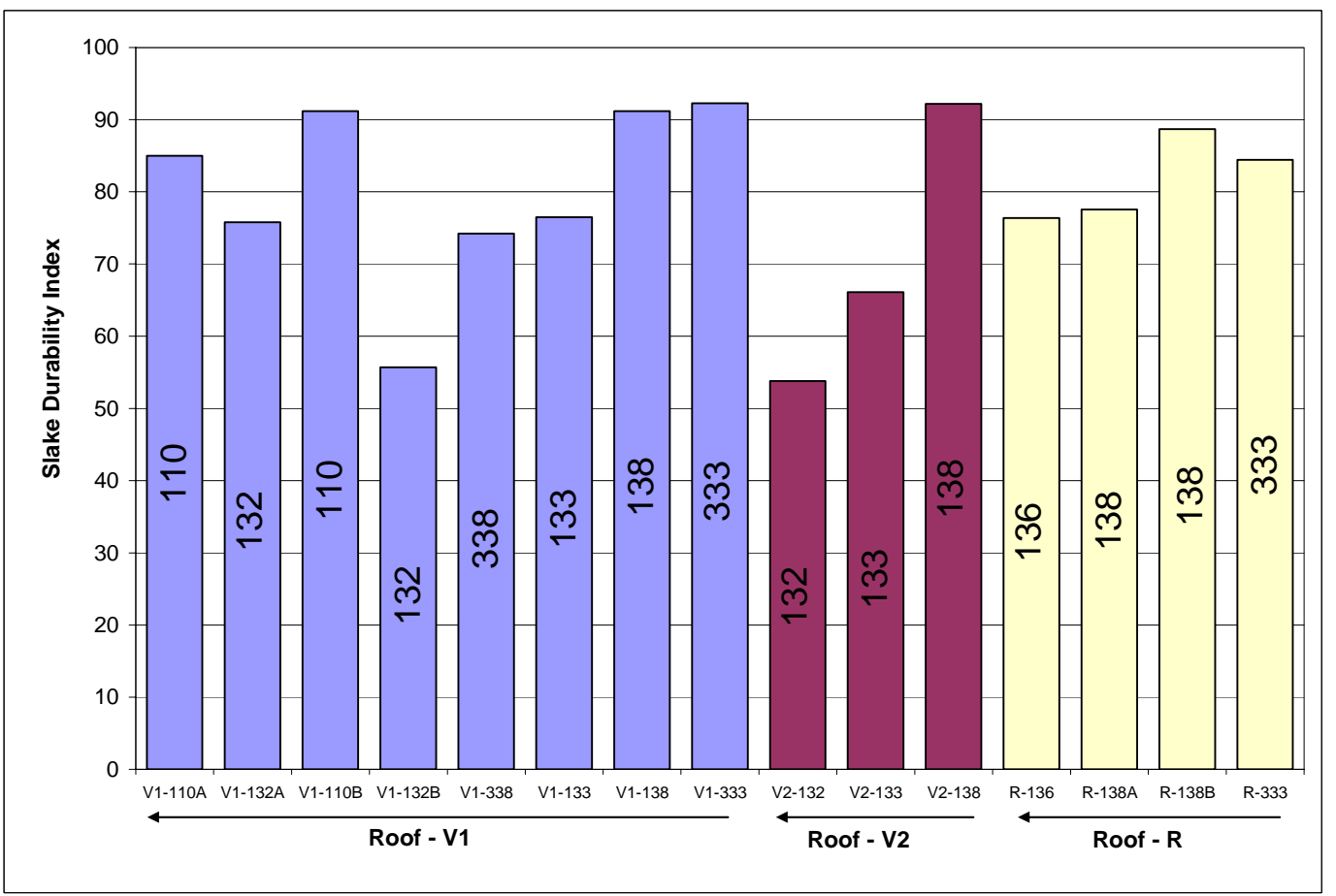

Figure 4.3: Slake durability indices for second cycle 
The test photos below are good illustrations of the effect of the slake durability cycles on the immediate roof shales of each hole. The photos in Figures 4.4 and 4.5 show the rocks after the first and second cycles, respectively. The remaining rock particles in the drum were classified into three groups as:

1) Retained materials that are virtually unchanged (on the left top corner, if available)

2) Retained materials that consist of large and small pieces (on the top right)

3) Retained materials that are exclusively small fragments (on the left bottom corner)

It is clear from the first cycle photos that the immediate roof rocks of Mine $\mathrm{R}$ have many pieces remaining unchanged, while most of the pieces from the immediate roof of Mine $\mathrm{V}$ were broken into fragments after the first slake durability cycle. Also, there are two unchanged pieces among the samples of R-138B after the second cycle. Thus, Mine V's immediate roof rocks show more durability and less deterioration by water submersion and mechanical agitation than Mine V's immediate roof shales. 

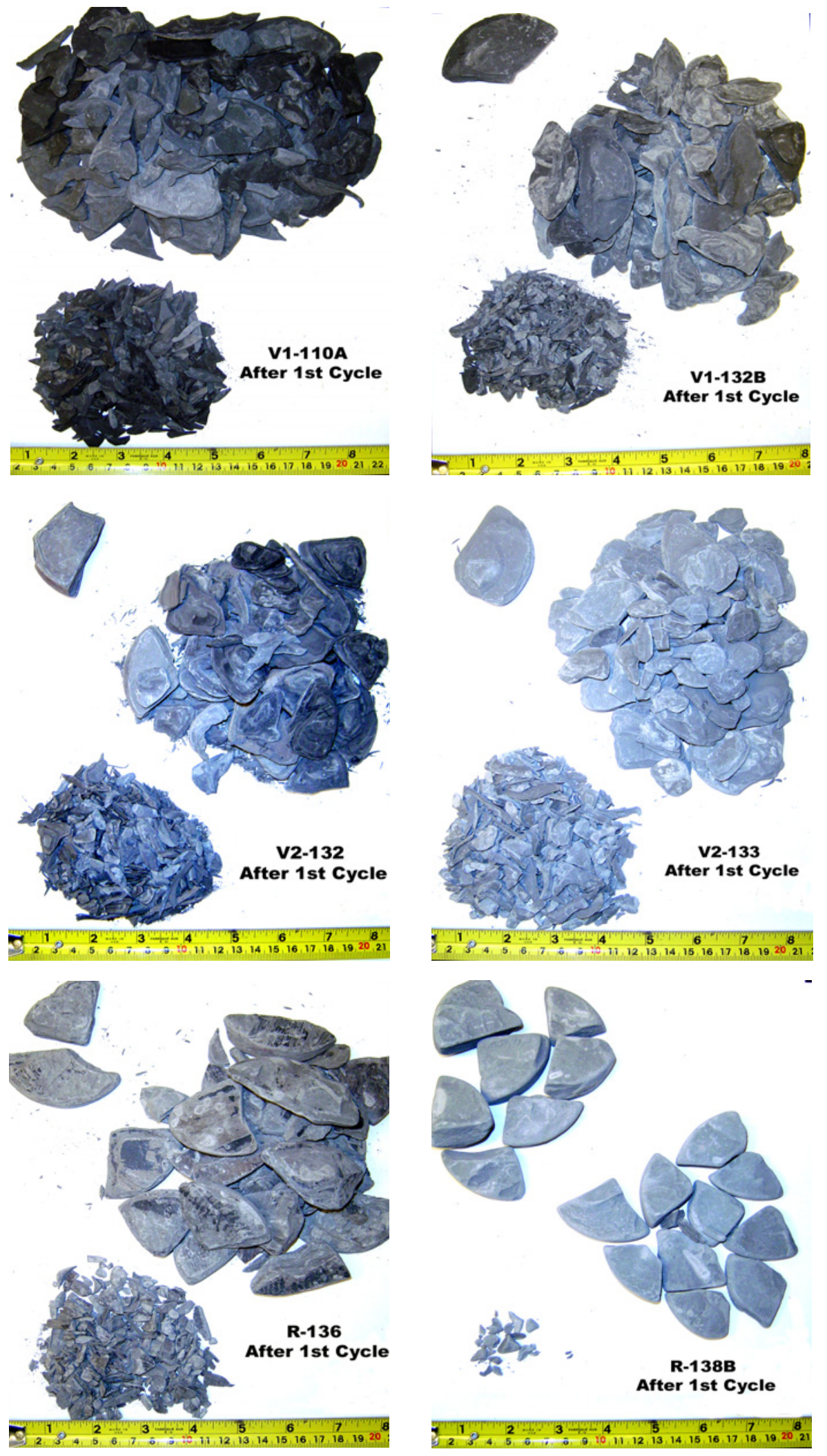

Figure 4.4: Rock fragments after the first cycle 

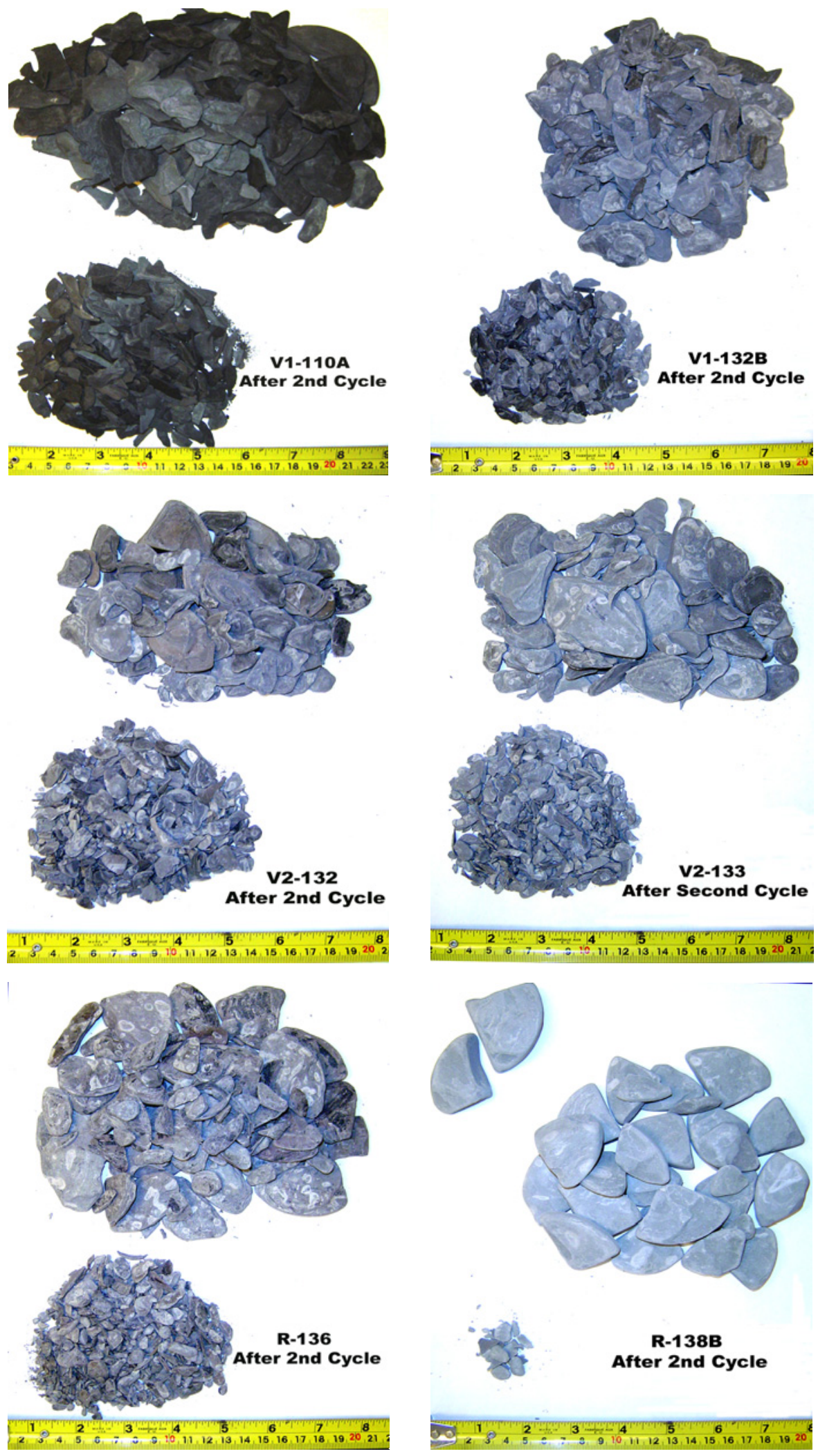

Figure 4.5: Rock fragments after the second cycle 


\subsection{Moisture Activity I ndex Test}

The complete test data are given in Appendix C (Actually, the weight of the samples was measured each day but only the weights of the significant dates (first and last days at the specific humidity levels) are indicated in the appendix). As mentioned before, the rocks were subjected to different relative humidity $(\mathrm{RH})$ levels in this test. From the $1^{\text {st }}$ through the $6^{\text {th }}$ day, the $\mathrm{RH}$ level is $20 \%$; from the $7^{\text {th }}$ to $17^{\text {th }}$ day, it is $50 \%$; from the $18^{\text {th }}$ to $33^{\text {rd }}$ day and $34^{\text {th }}$ to $53^{\text {rd }}$ day, it is $80 \%$ and $100 \%$, respectively. The increases in weight of the samples for each shale type from three drill holes are given Figures 4.6, 4.7 and 4.8 (the vertical scale for Hole V1 is different than the vertical scale for the other holes).

It was observed that it takes less time for the weight stabilization at the lower humidity levels than the higher ones. For example, at $20 \% \mathrm{RH}$, the rock weight became stable in 6 days. On the other hand, it took 20 days for the weight stabilization at $100 \% \mathrm{RH}$. The graphs also clearly show that the shales from the first hole absorbed much more moisture than the other holes. This shows that shales from Hole V1 are extremely sensitive to moisture. Moreover, all of the shale types show a common characteristic, i.e. there is a considerable weight change during first days of the humidity levels.

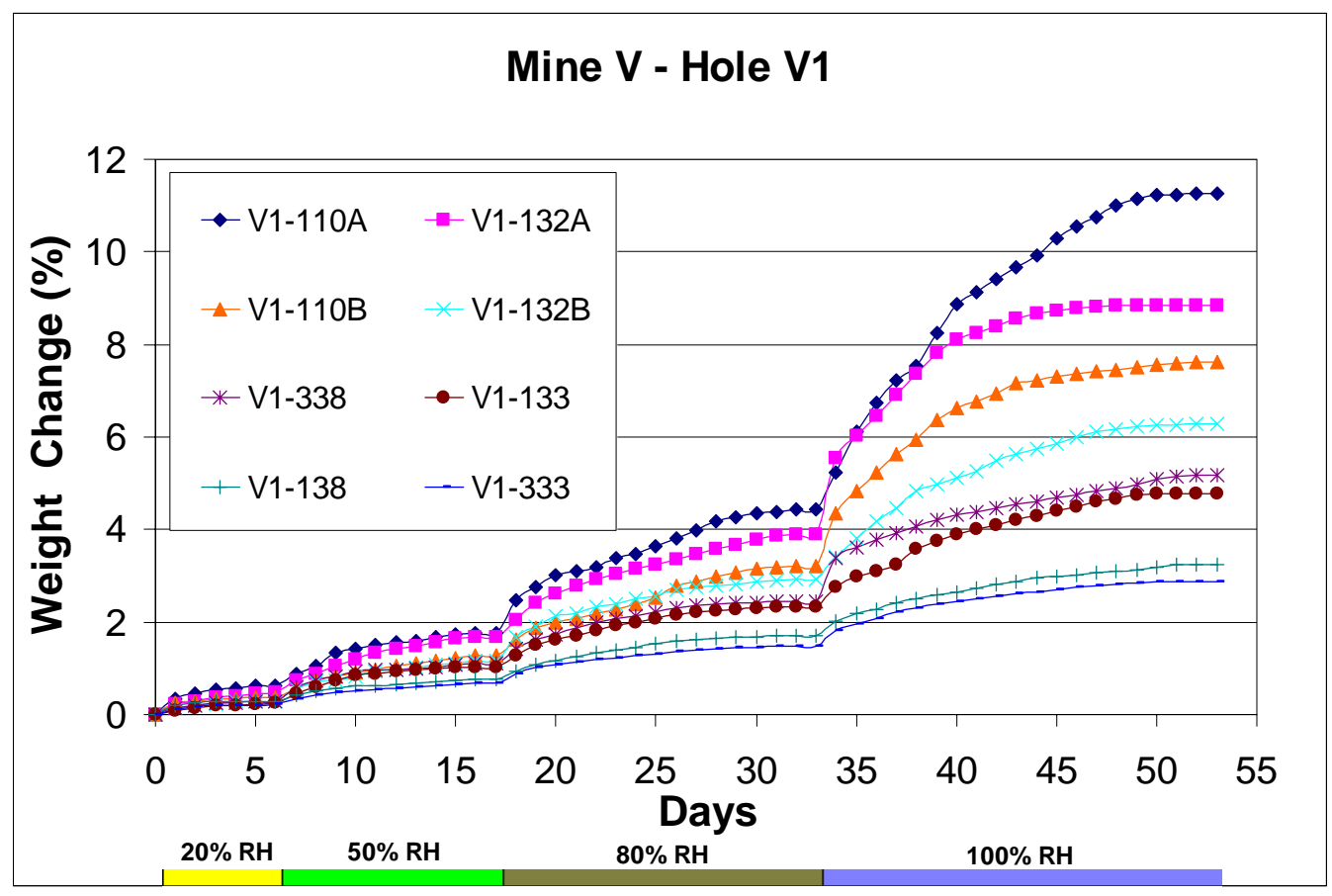

Figure 4.6: Increases in weight of shales from Hole V1 


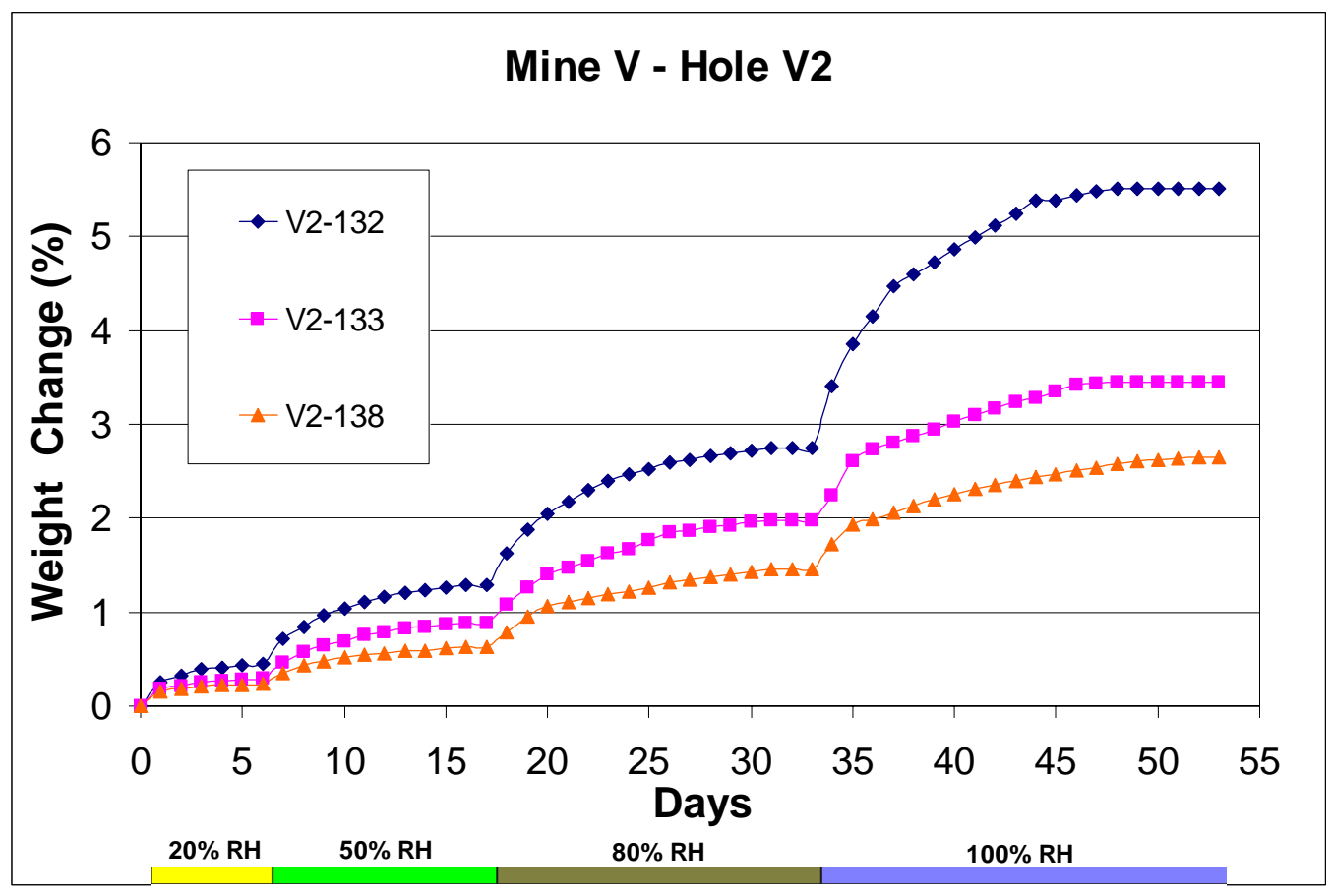

Figure 4.7: Increases in weight of shales from Hole V2

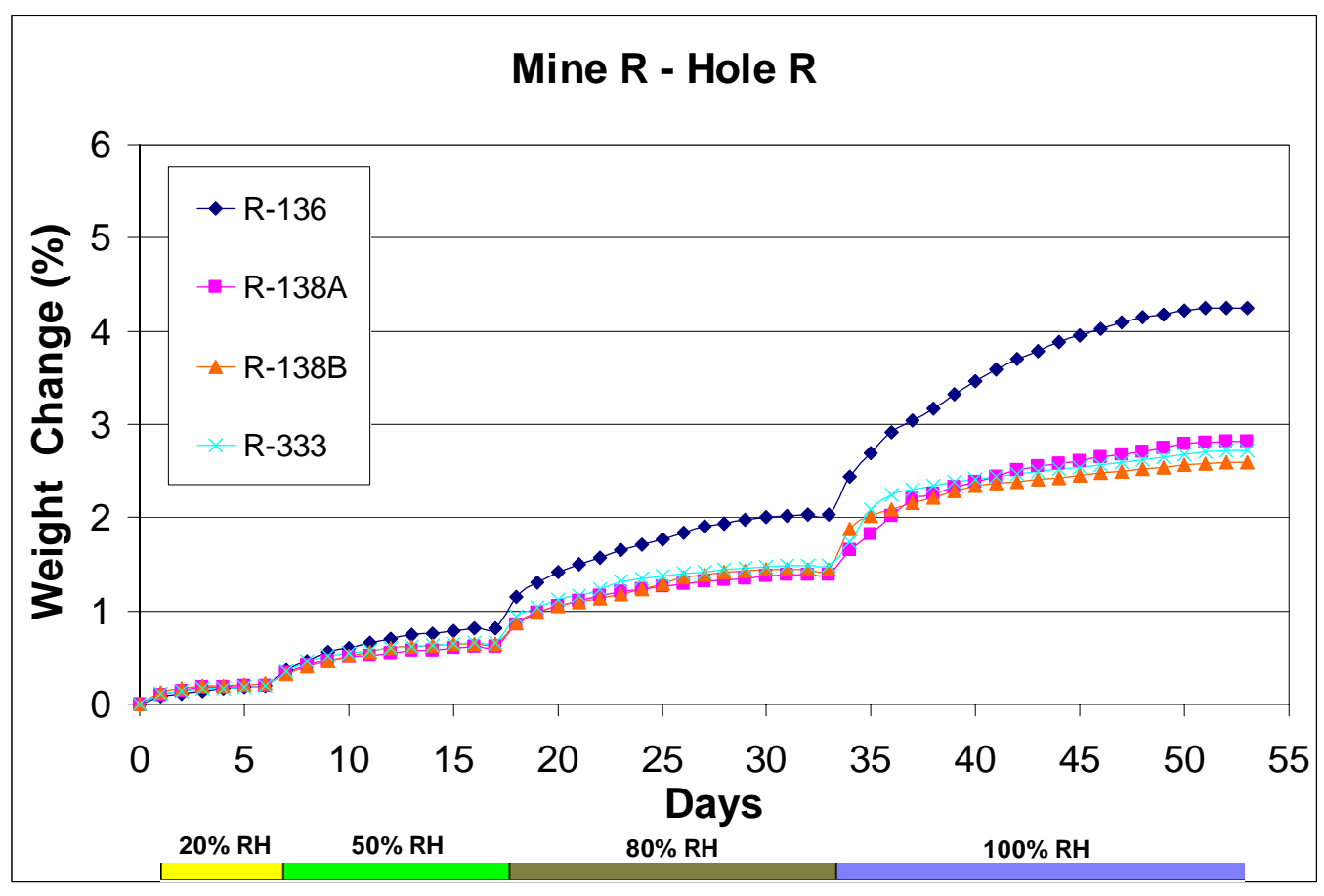

Figure 4.8: Increases in weight of shales from Hole $R$ 


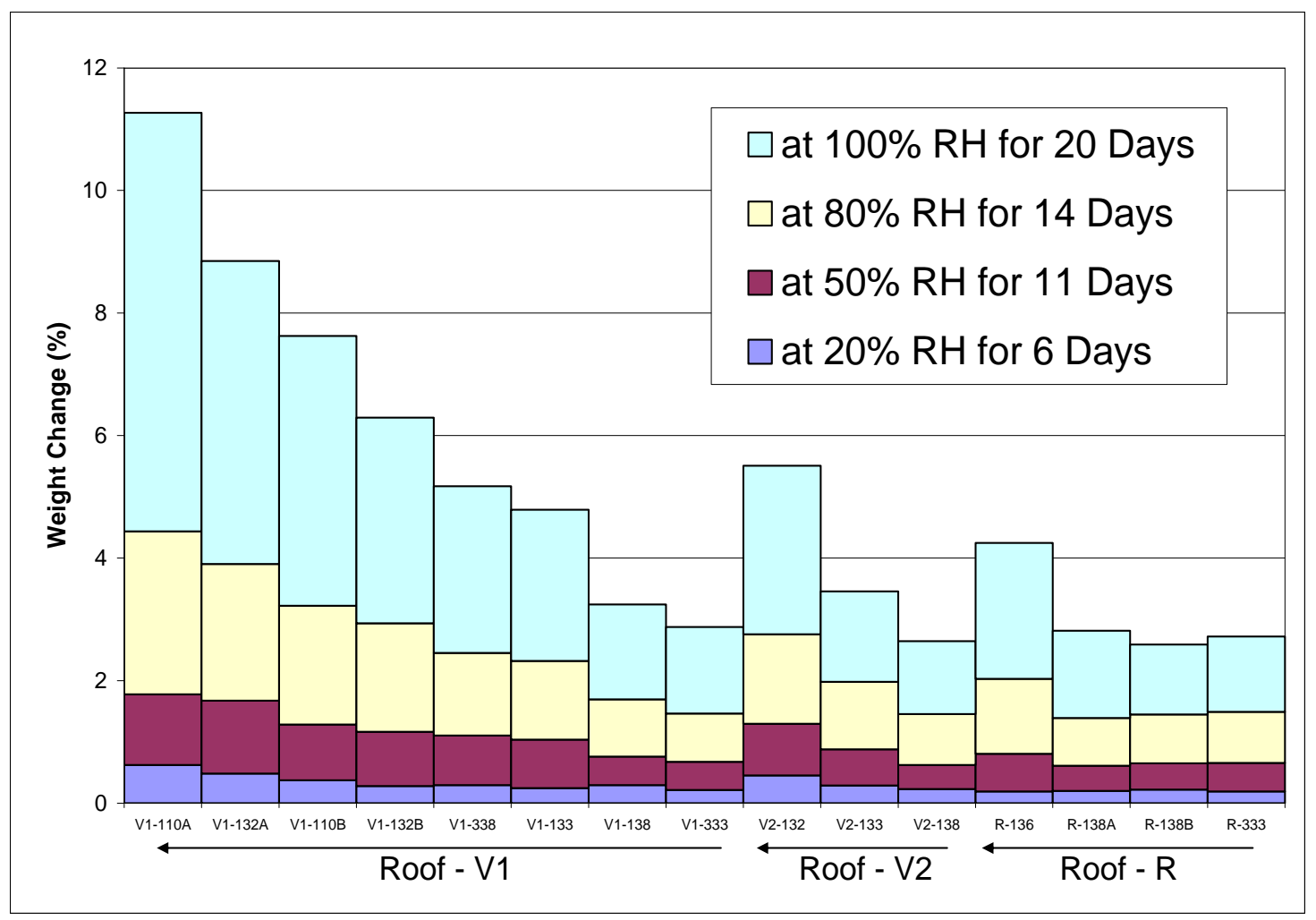

Figure 4.9: Moisture activity index test results

The moisture activity index test results are summarized in Figure 4.9. A very good correlation is found between the location of the sample and the moisture activity index. As the distance between the coal and the roof rock increases, the index value decreases. Also, it is clearly observed that the weight increase at $100 \%$ $\mathrm{RH}$ is much greater than the other levels.

This test evaluates the moisture susceptibility of rocks and the more weight change that is observed, the higher the moisture susceptibility of the rock. As it is mentioned before, Aughenbaugh classified the rock samples according to their moisture activity indices. Table 4.5 shows the moisture activity index values and the classification groups of the roof rocks.

According to these results, V1-110A, V1-132A and $\mathrm{V} 1-110 \mathrm{~B}$ have the highest moisture susceptibility and they are classified as non-durable rocks. Also, V1-132B, V1-338, V1-133, V2-132 and R-136 have high moisture activity indices and they are classified as moisture sensitive rocks that could deteriorate and become unstable when exposed to the humid mine atmosphere. These two groups of shales will be expected to cause ground control problems, if not sealed or properly supported. 
Furthermore, V1-138, V1-333, V2-133, V2-138, R-138A, R-138B and R-333 are rocks that are mildly susceptible to humidity changes. None of these shales are stable rocks. From the data it indicates that shales from Mine $\mathrm{V}$ are more susceptible to moisture than the shales from Mine R. In fact, the immediate roof rocks from Hole V1 having Ferm Numbers of 132 and 110 could absorb extremely high moisture compared to the other shales from V2 and R. These results show that extreme care must be taken with these shales, and contact between the air and these shale types should be cut, otherwise they are very likely to become weaken, deteriorate and cause ground control problems.

Table 4.5. Moisture activity index

\begin{tabular}{|c|c|c|c|c|c|c|}
\hline Mine & Hole & Rock Code & $\begin{array}{c}\text { Increase in } \\
\text { Weight at } \\
20 \% \text { RH } \\
(\%)\end{array}$ & $\begin{array}{c}\text { Increase in } \\
\text { Weight at } \\
100 \% \mathrm{RH} \\
(\%)\end{array}$ & $\begin{array}{l}\text { Moisture } \\
\text { Activity } \\
\text { Index }\end{array}$ & $\begin{array}{c}\text { Classification } \\
\text { Group }\end{array}$ \\
\hline \multirow{11}{*}{ 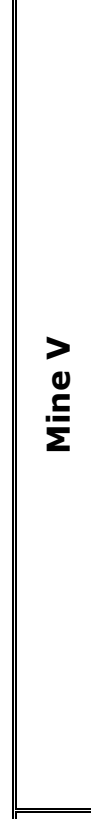 } & \multirow{8}{*}{$\begin{array}{l}5 \\
\frac{5}{0} \\
\frac{0}{1}\end{array}$} & V1-110A & 0.62 & 11.27 & 10.65 & 4 \\
\hline & & $\mathrm{V} 1-132 \mathrm{~A}$ & 0.48 & 8.85 & 8.36 & 4 \\
\hline & & $\mathrm{V} 1-110 \mathrm{~B}$ & 0.37 & 7.63 & 7.25 & 4 \\
\hline & & $\mathrm{V} 1-132 \mathrm{~B}$ & 0.28 & 6.29 & 6.01 & 3 \\
\hline & & V1-338 & 0.29 & 5.17 & 4.88 & 3 \\
\hline & & V1-133 & 0.25 & 4.79 & 4.54 & 3 \\
\hline & & V1-138 & 0.29 & 3.24 & 2.95 & 2 \\
\hline & & V1-333 & 0.22 & 2.88 & 2.66 & 2 \\
\hline & \multirow{3}{*}{$\begin{array}{l}N \\
\frac{N}{0} \\
1\end{array}$} & V2-132 & 0.45 & 5.51 & 5.06 & 3 \\
\hline & & V2-133 & 0.29 & 3.45 & 3.17 & 2 \\
\hline & & V2-138 & 0.23 & 2.64 & 2.41 & 2 \\
\hline \multirow{4}{*}{$\stackrel{\mathscr{\alpha}}{\underline{\underline{E}}}$} & \multirow{4}{*}{$\begin{array}{l}\frac{\alpha}{0} \\
\frac{0}{0}\end{array}$} & $R-136$ & 0.19 & 4.25 & 4.06 & 3 \\
\hline & & $R-138 A$ & 0.20 & 2.81 & 2.61 & 2 \\
\hline & & $\mathrm{R}-138 \mathrm{~B}$ & 0.22 & 2.59 & 2.37 & 2 \\
\hline & & $R-333$ & 0.19 & 2.72 & 2.53 & 2 \\
\hline
\end{tabular}




\subsection{Water (Moisture) Content Determination Test}

The original water content of the roof rocks are determined by this test. The test data are given in Appendix $D$ and the results are illustrated in Figure 4.10. It can be clearly seen that the water content of the shales decreases from the immediate roof to the main roof. These results may not exactly reflect the insitu case because there is a time difference between the drilling date and the test date. Although samples were sealed, there is a possibility to have inaccurate results. For instance, the results of the second drill hole (V2) seem to be inaccurate compared to the other holes. There is a big difference between the water content of the immediate roof rocks of $\mathrm{V} 1$ and the rocks from the other two holes. In fact, more than $6 \%$ moisture was observed in V1-110A and V1-132A.

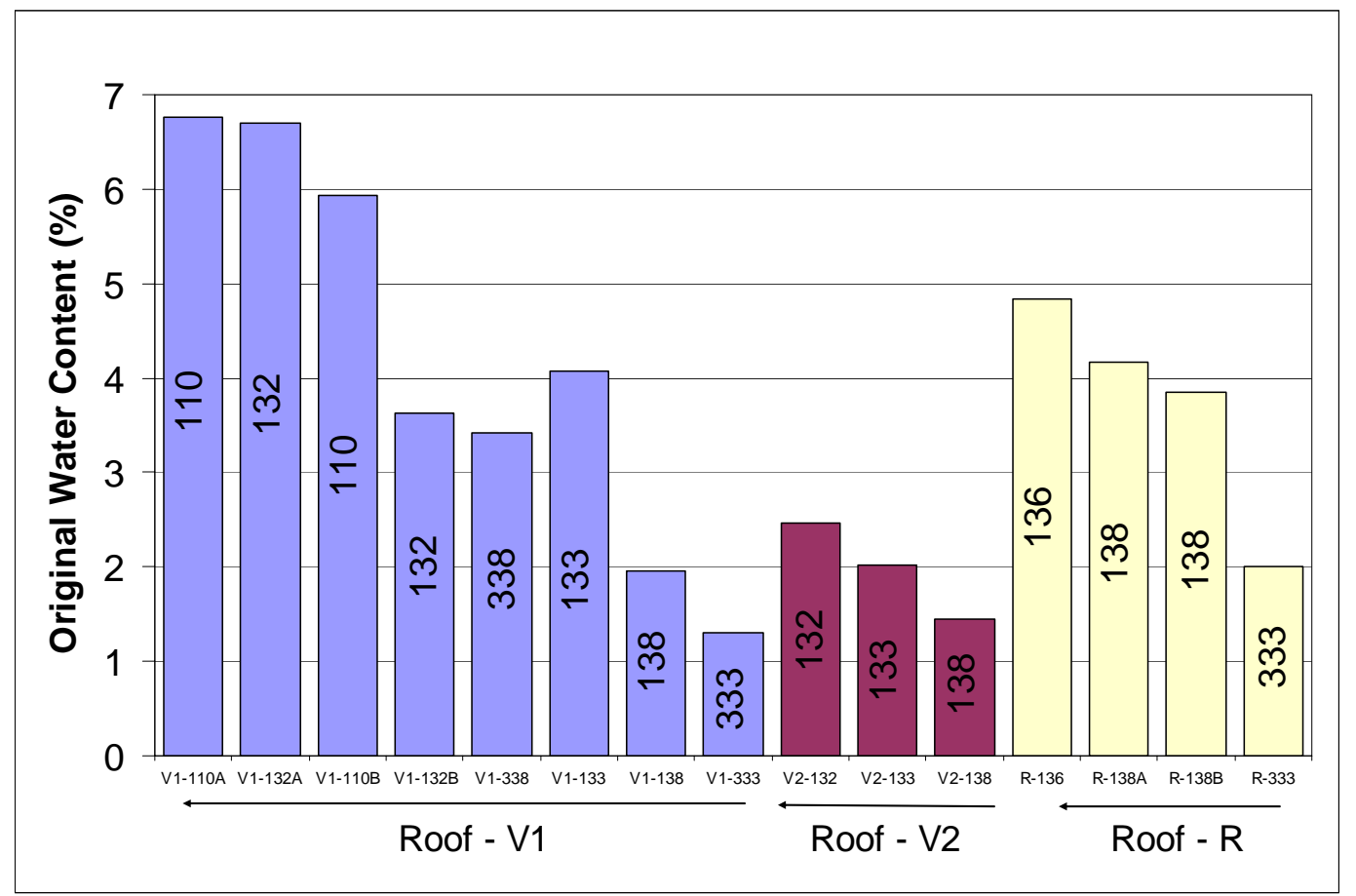

Figure 4.10: Water (moisture) content of the tested shales

\subsection{Weatherability Index Test}

The test data is given in the table of Appendix E, and Figures 4.11 and 4.12 illustrate the situation before and after the weatherability index test. The difference between Figures 4.11 and 4.12 clearly shows the effect of the wetting and drying cycles (3 complete cycles). 


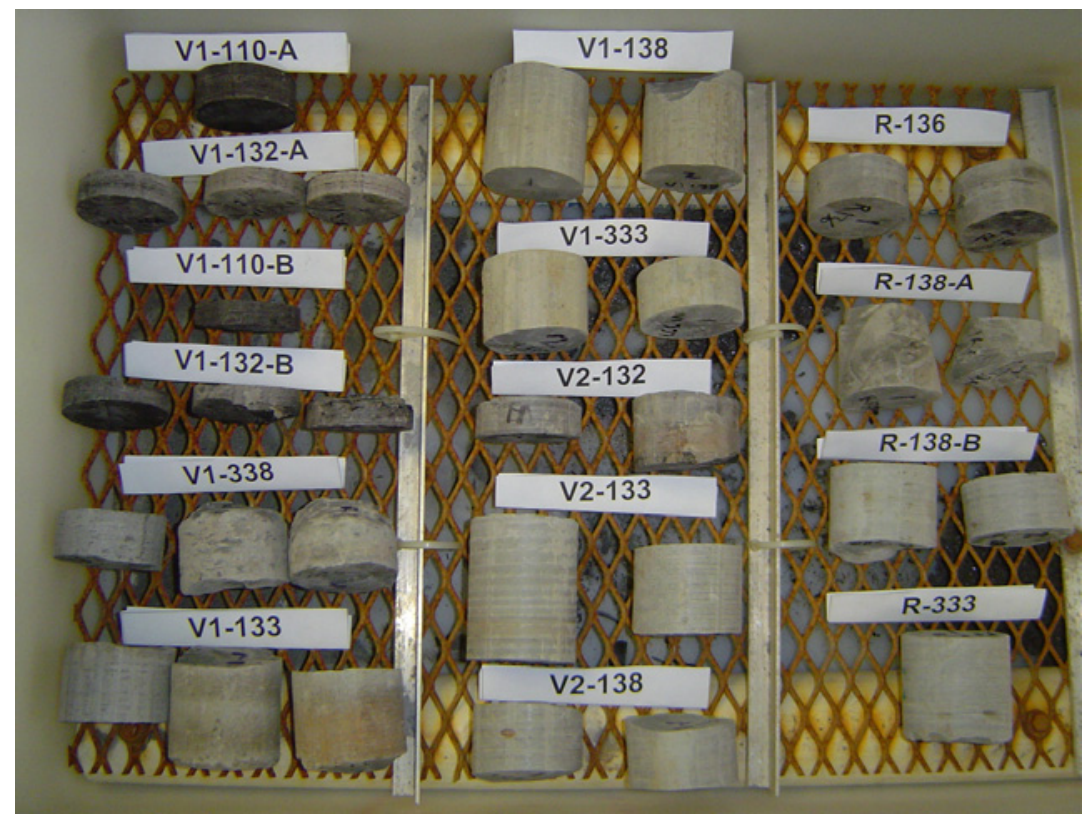

Figure 4.11: Before weatherability index test

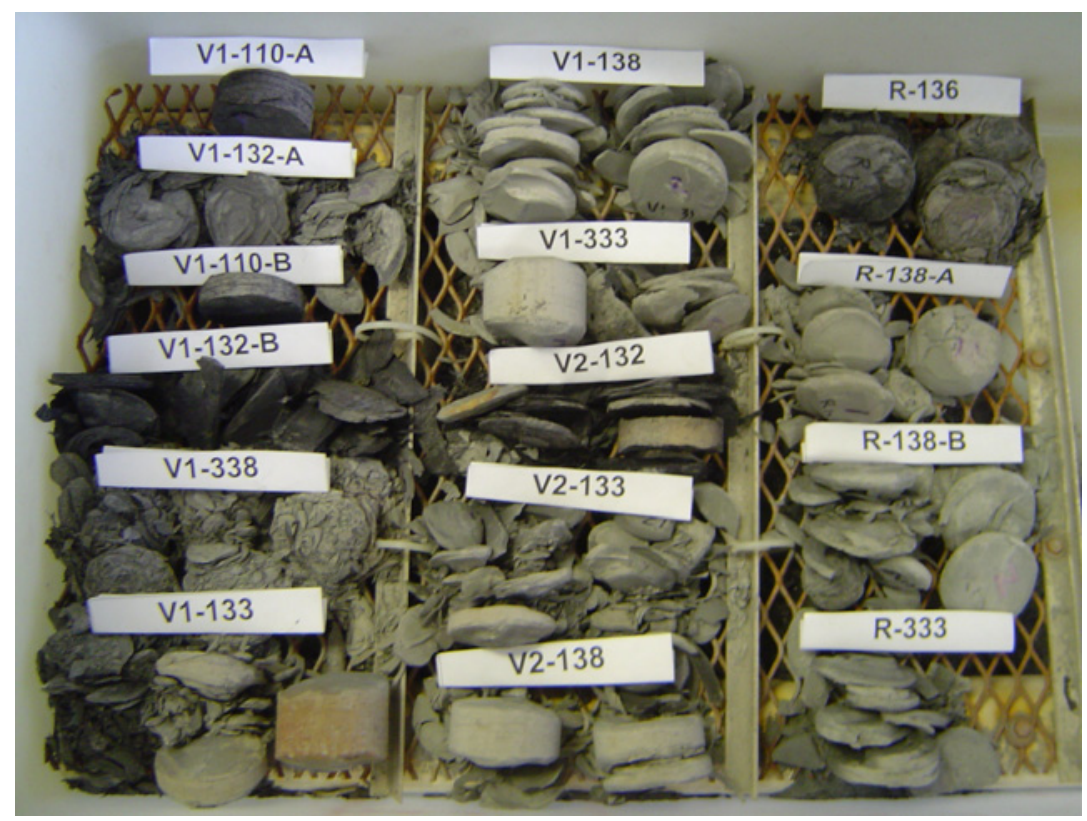

Figure 4.12: After weatherability index test

The average weatherability indices of the roof rocks are summarized in the Figure 4.13. Very low index values are seen with the rocks having 110 Ferm Numbers. This means that wetting and drying cycles have no effect on this type of shales. On the other hand, shales with 132 Ferm Number have very high weatherability indices and Figures 4.11 and 4.12 clearly indicate that these rocks almost entirely deteriorated from the weathering effect. Rocks with Ferm Numbers of 
338 and 133 also show high sensitivity to weathering. Although V1-138 has a weatherability index close to $80 \%, \mathrm{~V} 2-138$ 's index value is close to $30 \%$, and R-138A and $\mathrm{R}-138 \mathrm{~B}$ have indices of $57 \%$ and $74 \%$, respectively. Thus, it is difficult to conclude the exact weathering behavior for this type of shale. Similarly, a conclusion cannot be made for the shale with Ferm Number of 333.

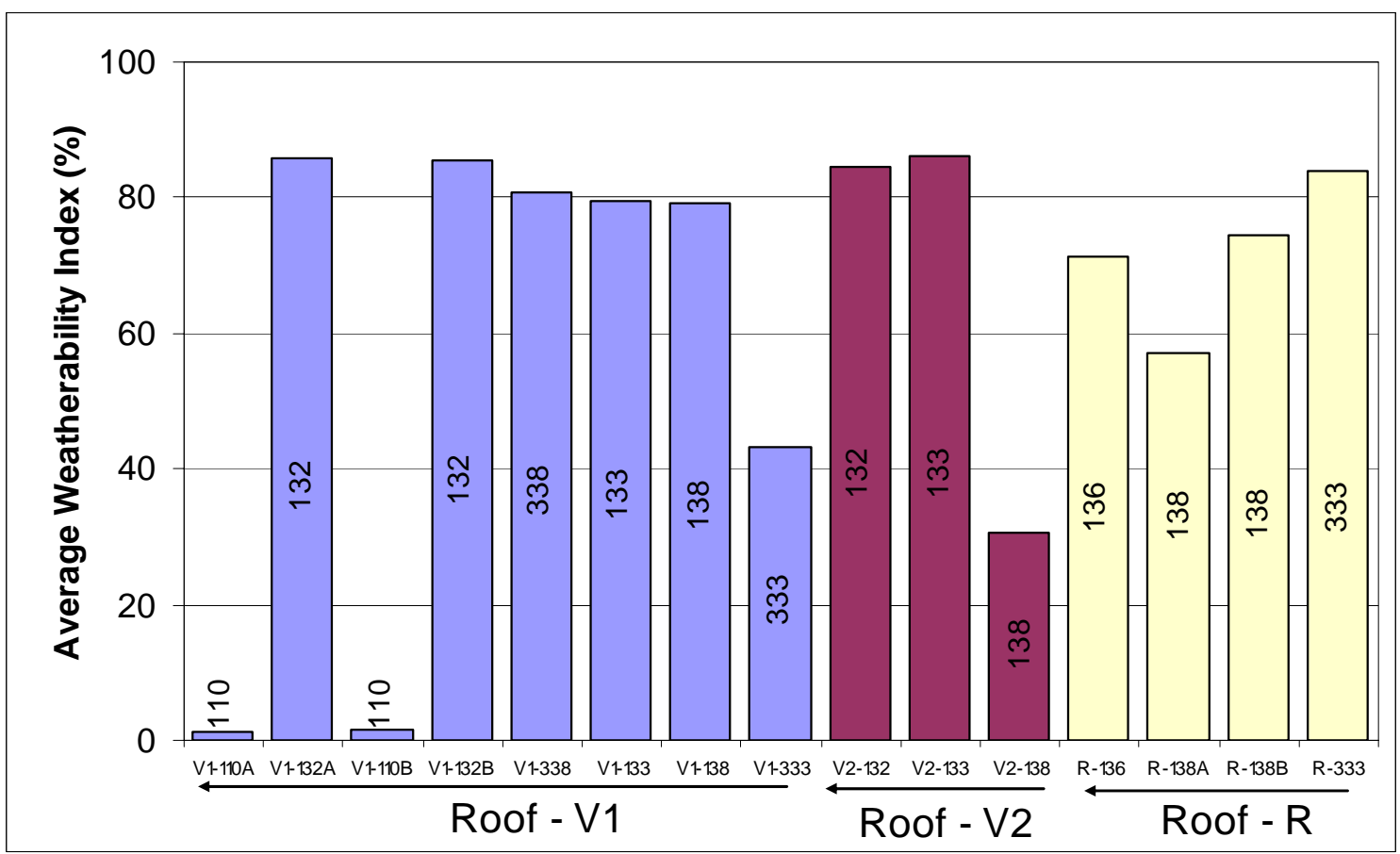

Figure 4.13: Average weatherability indices of the roof shales

In addition to this study, another analysis was done to compare the weathering behavior of the immediate roof shales of Mine $V$ with other immediate roof rocks of different coal mines located all around the U.S (unfortunately, Mine R rocks were not available during this analysis). For this study, 10 additional mines were included and a comparison was made with Mine $\mathrm{V}$. The pictures of this study are given in Appendix $E$ and the weatherability indices of the rocks from 11 different coal mines are summarized in Figure 4.14. Both pictures and the index values clearly indicate that roof rocks from Mine $B$ and Mine $V$ have very high sensitivities to weathering. In fact, the rock sample from Mine B was entirely disintegrated after the test. Similarly, about $95 \%$ of the samples from Mine $V$ were disintegrated due to the weathering cycles. To sum up, it can be said that Mine $V$ has very sensitive immediate roof rocks to weathering compared to roof rocks of other coal mines in the U.S. 


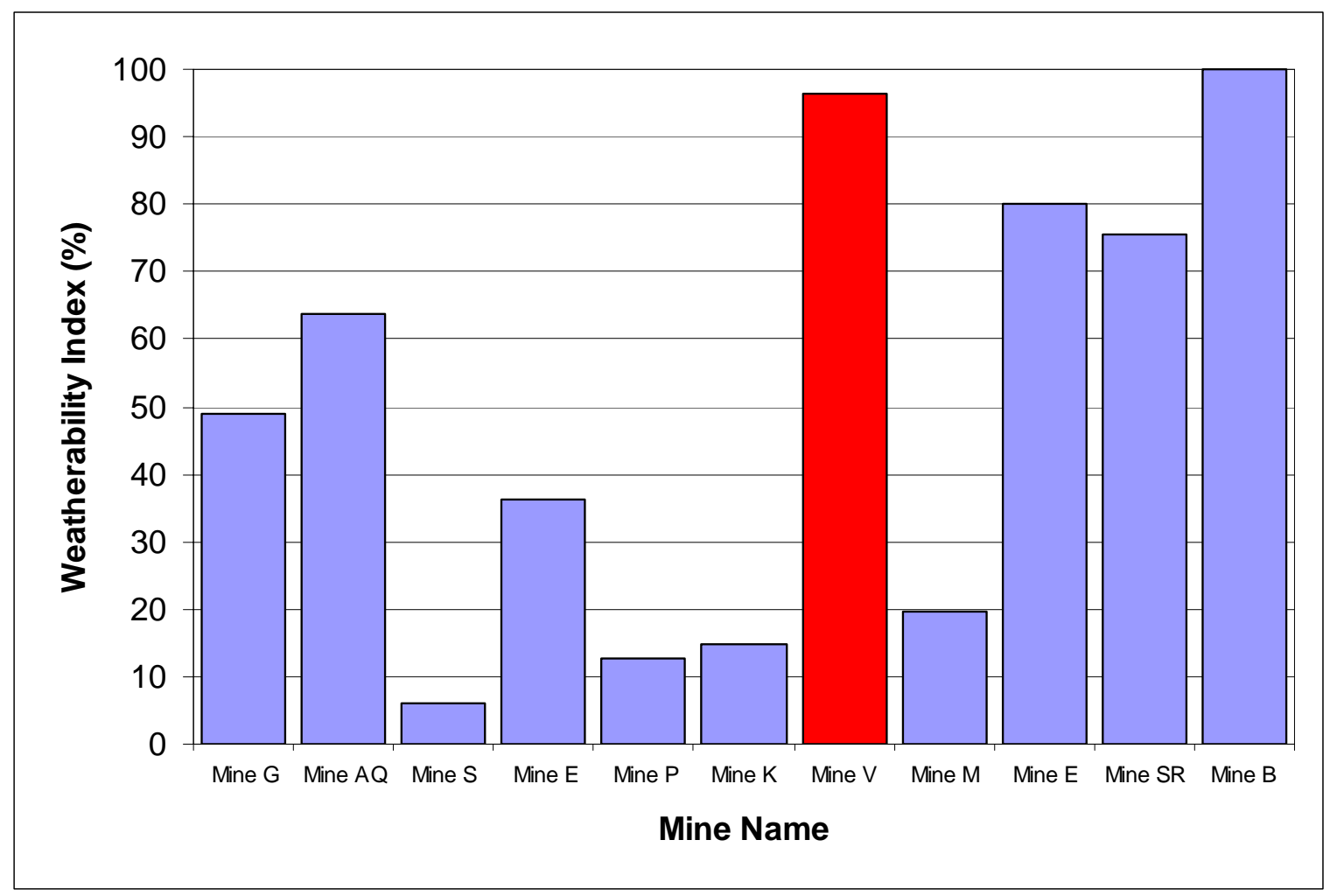

Figure 4.14: Weatherability index results of the roof rocks of $11 \mathrm{U.S.}$ coal mines including Mine $\mathbf{V}$

\subsection{Swelling Strain Test}

First of all, one shale specimen from V1 was tested by using 5 dial indicators (4 lateral and 1 vertical). As it can be observed from Figure 4.15, vertical swelling is almost 10 times greater than the lateral swelling. Therefore, lateral strain is insignificant. The volumetric swelling strain is also calculated and the curve is given in Figure 4.16. The total volumetric strain at the end of the test is found to be $2.52 \%$. As it was mentioned in the previous chapter, the rocks were subjected to different humidity levels in this test. From the $1^{\text {st }}$ through the $6^{\text {th }}$ day the RH level is $20 \%$, from the $7^{\text {th }}$ to $17^{\text {th }}$ day it is $50 \%$, from the $18^{\text {th }}$ to $33^{\text {rd }}$ day and $34^{\text {th }}$ to $53^{\text {rd }}$ day it is $80 \%$ and $100 \%$, respectively. 


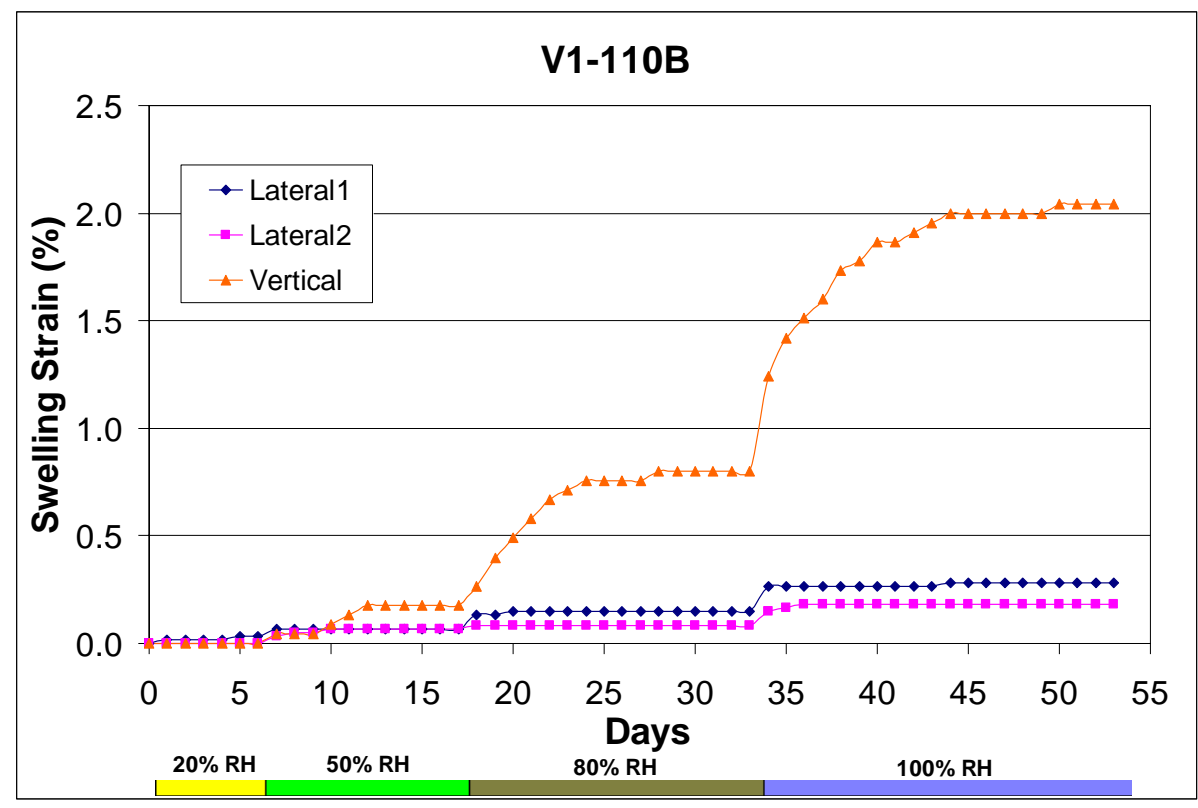

Figure 4.15: Lateral and vertical swelling strain of V1-110B

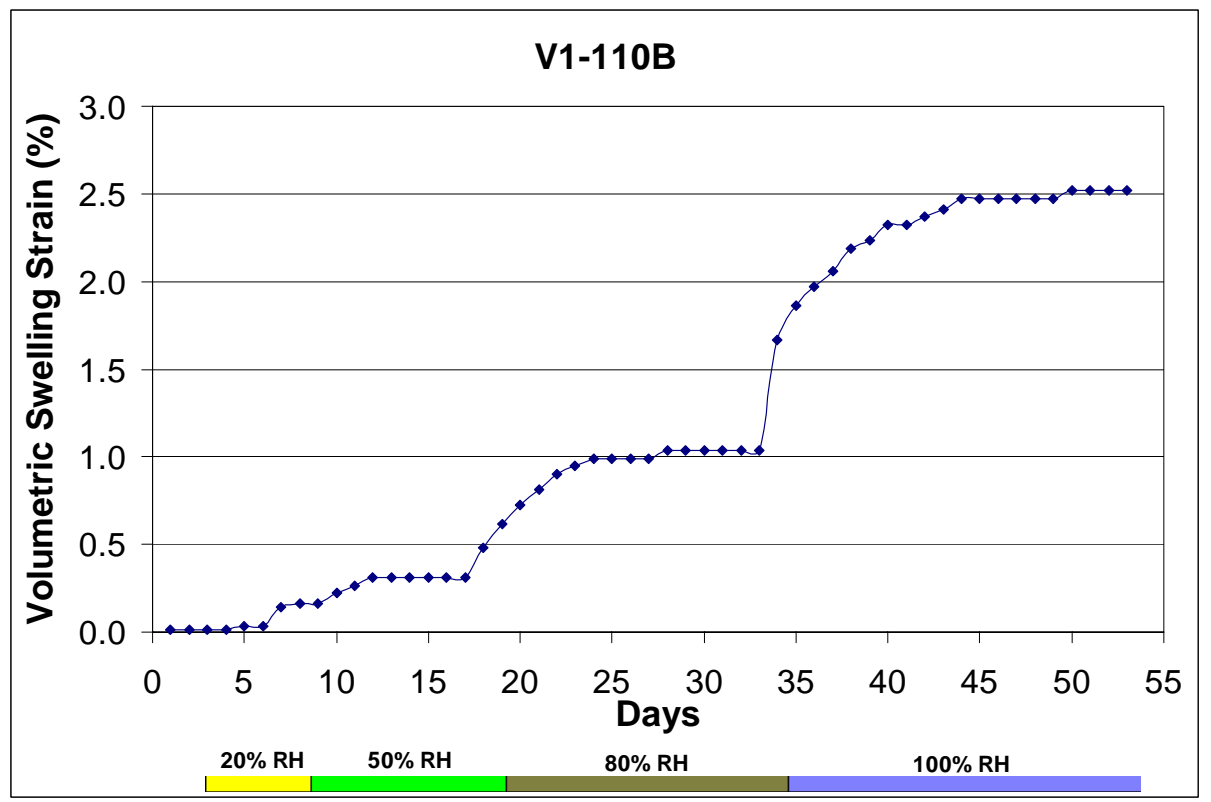

Figure 4.16: Volumetric swelling strain of V1-110B

Since the lateral strain was insignificant in the first test, in subsequent tests only 3 dial indicators (2 lateral and 1 vertical) were employed for each sample. V2132 and R-136 were tested simultaneously. The results are shown in Figure 4.17. Again, these results indicate that there is a big difference between the lateral and vertical swelling strains. The volumetric strains are also calculated to be $3.40 \%$ and $2.30 \%$ for $\mathrm{V} 2-132$ and $\mathrm{R}-136$, respectively. 

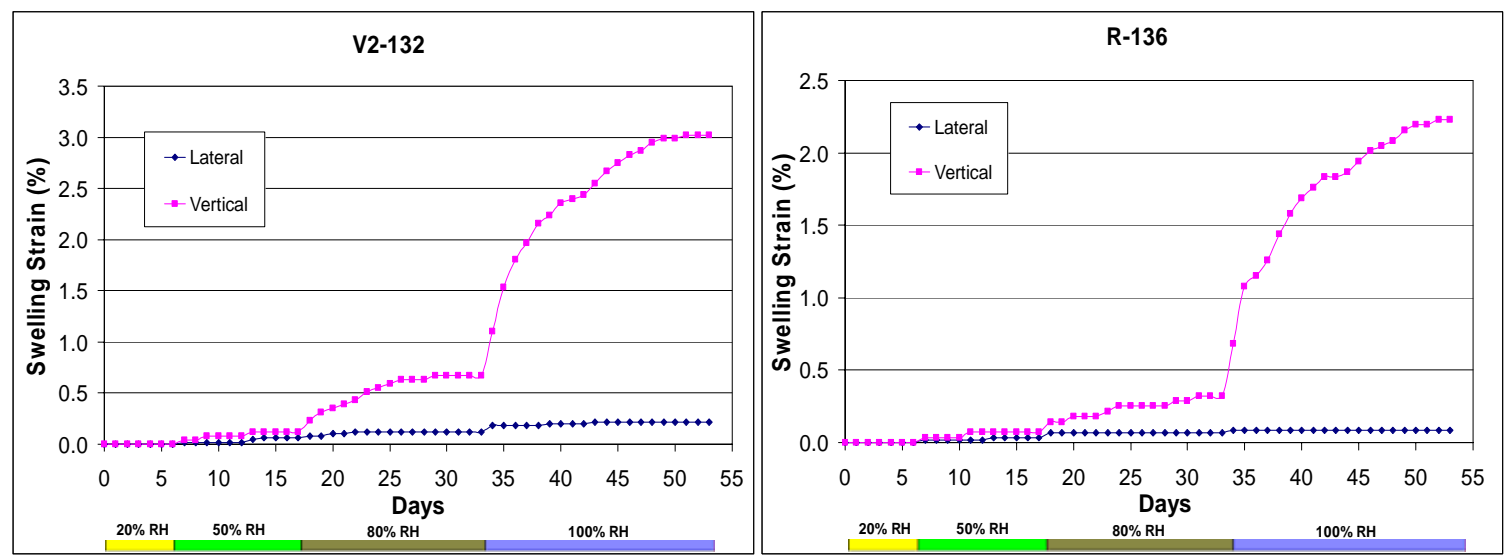

Figure 4.17: Lateral and vertical swelling strain of V2-132 and R-136

After running three tests, it was decided that measurement of lateral strain is useless for these shale types and only vertical strain was taken into consideration for the subsequent experiments. The vertical swelling strain test data is given in Appendix $F$ and the results are summarized for each drill hole rock group in Figures $4.18,4.19$ and 4.20 .

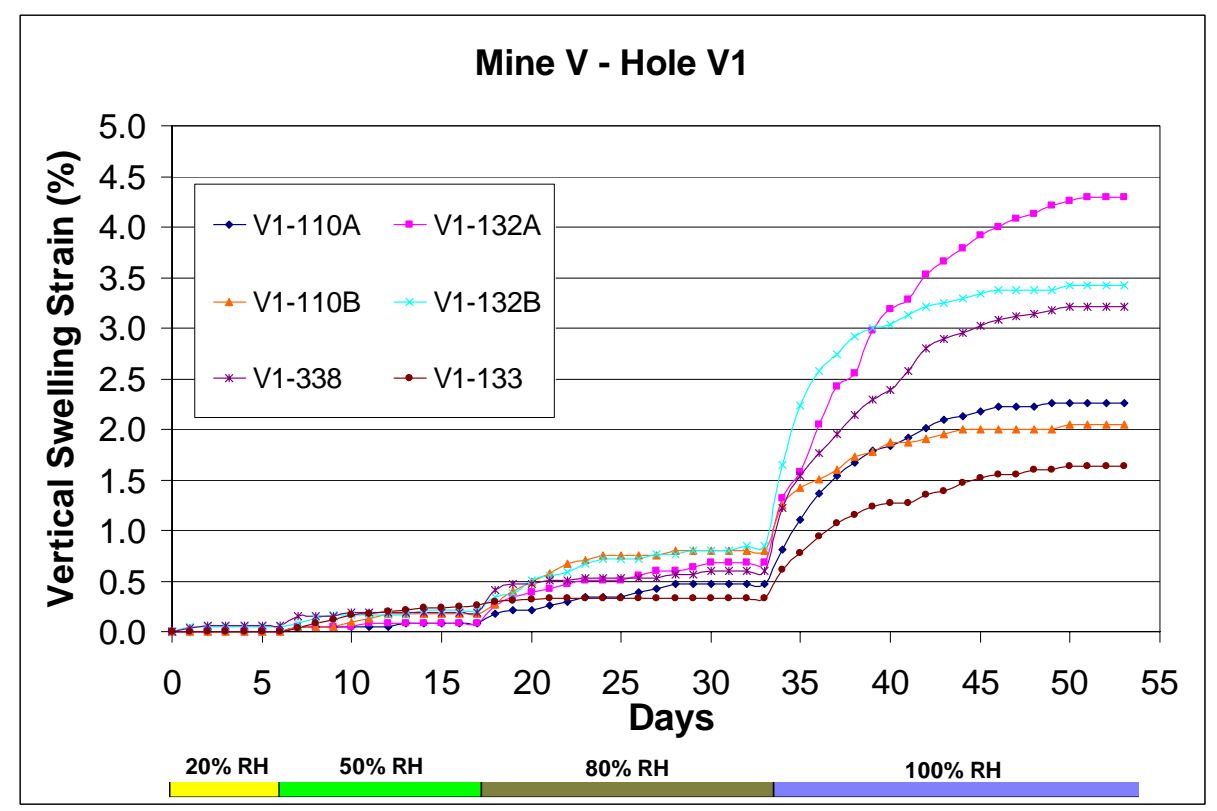

Figure 4.18: Vertical swelling strain of shales from Hole V1 


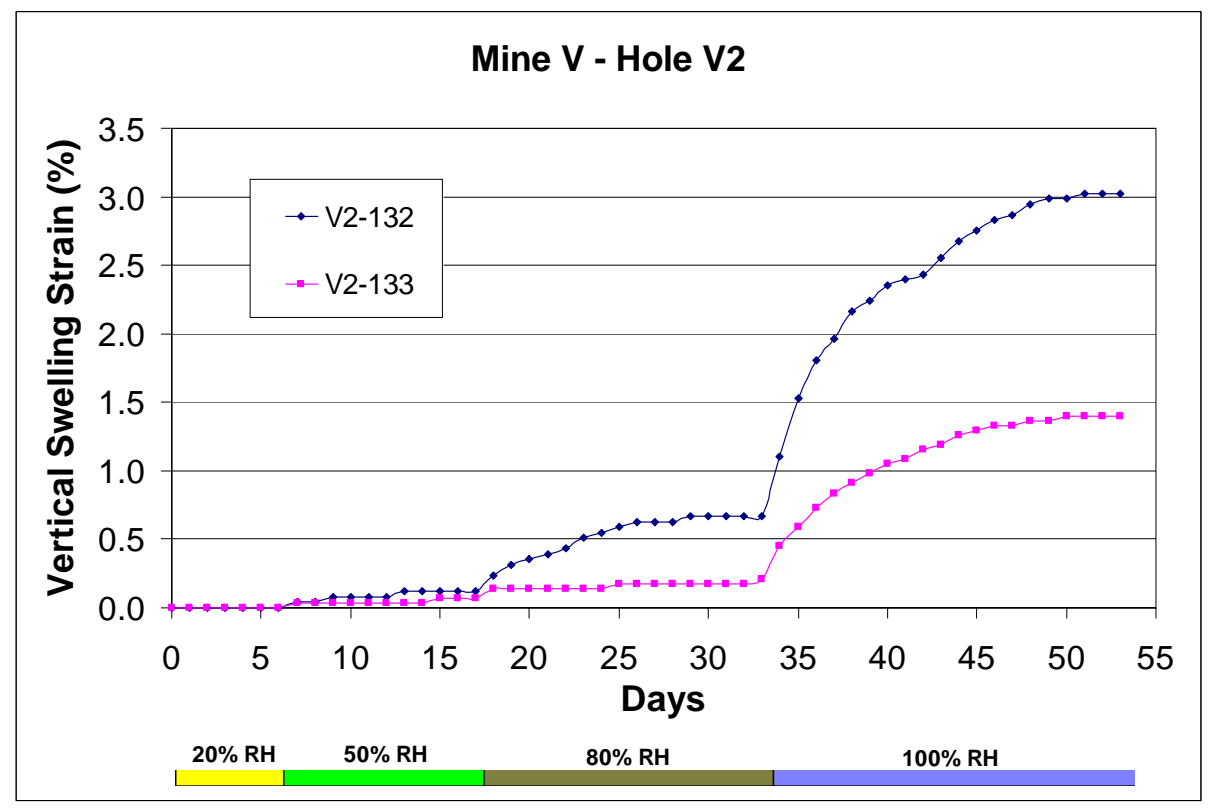

Figure 4.19: Vertical swelling strain of shales from Hole V2

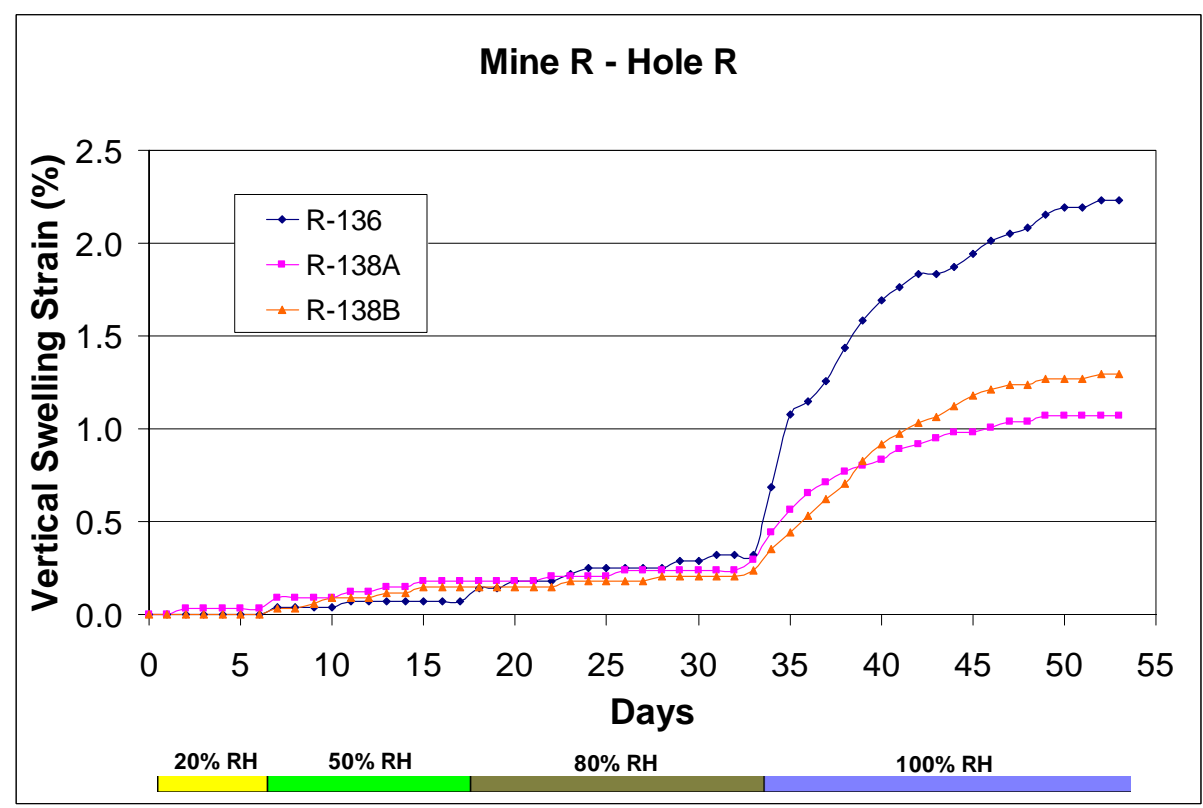

Figure 4.20: Vertical swelling strain of shales from Hole $\mathbf{R}$

From the swelling curves of these shales, it is observed that during the periods under $20 \%, 50 \%$ and $80 \% \mathrm{RH}$, the swelling strain values are very small compared to the large increase at $100 \% \mathrm{RH}$. All of the shales in this study behaved similar. However, some of these shales from Mine $V$ such as Ferm Numbers 132 and 338 had vertical swellings greater than $3 \%$, which can be considered significant expansions. Notably, V1-132A expanded the most with a strain of $4.30 \%$. On the 
other hand, shale types with 110 and 136 Ferm Numbers had moderately high expansion, while 133 and 138 Ferm Number shales had insignificant expansion. For instance, R-138A only expanded $1.07 \%$ throughout the test.

\subsection{X-ray Diffraction Test}

Four samples from Mine $\mathrm{V}$ and Mine $\mathrm{R}$ were sent to the laboratories of the Department of Chemical Engineering at West Virginia University for mineral content analysis by the x-ray diffraction test. Unfortunately, the number of tested samples was limited and a very detailed analysis could not be made. Only four shale types from Holes V1 and R, which are; V1-132A, V1-338, R-136 and R-138A could be analyzed and the x-ray diffraction curves of the analyses are given in Figure 4.21. The detailed curves indicating the minerals at every peak point are given in Appendix G.

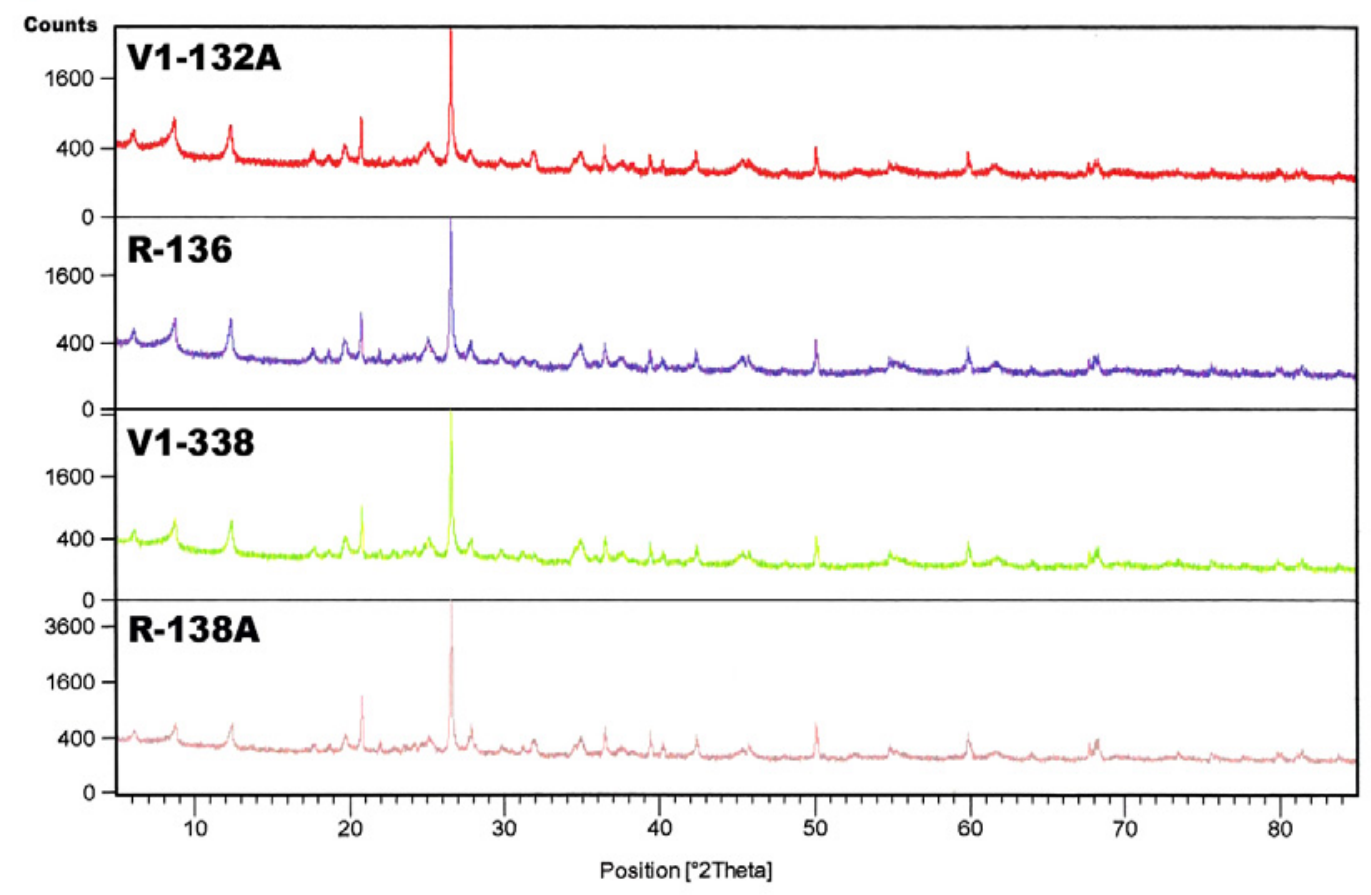

Figure 4.21: X-ray diffraction test

From the results of the $x$-ray diffraction test, it is seen that all of the samples behaved almost the same way. The intensity (counts) versus position ( ${ }^{0} 2$ Theta) graphs of these four shale samples looks very similar to each other. However, there are some minor differences in mineral contents. The major minerals found in this analysis are; illite, muscovite, clinochlore, siderite, albite and quartz. Clinochlore and 
quartz are found in all of the four samples. Albite is also common in all of them expect for V1-132A. Besides, V1-338 and R-136 include illite, whereas V1-132A and $\mathrm{R}-138 \mathrm{~A}$ include muscovite. In fact, it is found that muscovite and illite are similar clay minerals having almost the same properties. Moreover, siderite is only found in V1-132A.

As mentioned earlier, these samples are different types of shales but their mineralogical content seems to be very close to each other. Although it was expected to see problem clay minerals such as montmorillonite, smectite or vermiculite in these shales, these minerals are not present. However, siderite, found in the immediate roof of the Mine $\mathrm{V}$, can be considered as a problem mineral due to its weak behavior. Since these shale types are weak, moisture sensitive and likely to expand significantly, the minerals that were found may cause swelling or weakness in their host rock. The following explains the nature of the significant minerals that were found in this analysis.

Illite is normally a non-expanding clay. Its platens are stacked and tightly bound to each other by cationic bonding, which cannot be easily broken by ordinary means. In the case of illite, the substitution between the sheets has developed to a large extent, especially $\mathrm{Al}$ for $\mathrm{Si}$ on the tetrahedral layer. The excess negative charge is sufficiently high that interlayer potassium dehydrates and bonds the cation strongly between the layers. However, the fine grain size of many illites can lead to significant swelling. In fact, fine grained illites can behave similarly to montmorillonite with low surface areas. Most illite clays have a bonding strength and low plasticity, but there are some varieties that have a bonding strength approaching that of montmorillonite.

Illite bonding clays are produced extensively in Illinois. The illite in these clays is finer-grained and more easily dispersible in water than the relatively less plastic illite in many clays and shales. This is probably because some weathering has partially removed the potassium between the unit layers. Found in a wide variety of environments, the materials of the illite series are formed by either weathering or hydrothermal alteration of muscovite-phengite, but some is autogenic or could be derived from alteration of $\mathrm{K}$-feldspars or recrystallization of smectites. Illite is common in sediments, clays, marls, shales and some slates. Interstratified illitesmectite converts to illite at depths [40 and 41]. 
Illite is also known as fine-grained muscovite. Therefore, muscovite and illite behaved similar in these curves. They also act similar in nature and have similar properties. Illite is a clay mineral, while muscovite belongs to the mica group. Muscovite can be seen by the naked eye, whereas it is almost impossible to see illite by the naked eye.

Siderite is another mineral that may cause swelling and weakness in its host rock. It is the most common of the mica group minerals. It is typically found as massively crystalline material. It is clear with a pearly luster on cleavage faces, often having a sparkly look in rocks. Siderite is the carbonate of iron and may occur in clay in the following forms:

- As concretionary masses known as clay-ironstones, ranging in size from a fraction of an inch to several feet in diameter. They are abundant in some carboniferous shales, and are often strung out in lines parallel with the stratification of the clay.

- In the form of crystalline grains, scattered through the clay and rarely visible to the naked eye.

- As a film coating other minerals in the clay. Siderite may be present in some surface clays, but it is probably of greatest importance in shales, notably those associated with coal-seams and may occur in either finely divided (disseminated) or concretionary form. Most often found in bedded sedimentary deposits with a biological component, with shales, clays and coal beds [40 and 41$]$.

Quartz is found at least in small quantities in almost all clays, whether residual or sedimentary, but the grains are rarely large enough to be seen with the naked eye. The chemical formulas and hardness of the minerals found in these shales are shown in Table 4.6.

It seems that illite, muscovite and siderite are the minerals that may be the reasons for the problems of the shales that were analyzed. However, a more detailed analysis may be needed to figure out the mineralogy clearly and to be conclusive about this topic. Many samples should be scanned in order to be sure about the mineral contents. Unfortunately, only four samples could be analyzed by x-ray 
diffraction test in this study. Elementary chemistry tests can also be done to determine the chemical composition of the minerals that are included in rock. Quantitative mineralogical analysis may also be needed for this kind of study.

Table 4.6. Minerals found by $x$-ray diffraction test

\begin{tabular}{|c|c|c|}
\hline Mineral Name & Formula & Hardness \\
\hline Muscovite & $\mathrm{KAl}_{2}(\mathrm{SiAl}) \mathrm{O}_{10}(\mathrm{OH})_{2}$ & 2.5 \\
\hline Illite & $\mathrm{K}_{0.65} \mathrm{~A}_{2.0}\left[\mathrm{Al}_{0.65} \mathrm{Si}_{3.35} \mathrm{O}_{10}\right](\mathrm{OH})_{2}$ & $1.0-2.0$ \\
\hline Quartz & $\mathrm{SiO}_{2}$ & 7.0 \\
\hline Albite & $\mathrm{Na}\left[\mathrm{AlSi}_{3} \mathrm{O}_{3}\right]$ & $6.0-6.5$ \\
\hline Clinochlore & $\left(\mathrm{MgFe}^{2+}\right)_{5} \mathrm{Al}\left(\mathrm{Si}_{3} \mathrm{Al}\right) \mathrm{O}_{10}(\mathrm{OH})_{3}$ & $2.0-2.5$ \\
\hline Siderite & $\mathrm{FeCO}_{3}$ & $3.5-4.5$ \\
\hline
\end{tabular}

\subsection{Correlations and Discussions}

The samples that were tested for the moisture activity index test were also subjected to axial point load test afterwards. The comparison of the original strength and the strength after the moisture activity index (MAI) test is shown in Figure 4.22. A very significant strength loss is observed. Moisture sensitive rocks such as 132 and 110 lost more than $65 \%$ of their original strength. This showed that moisture absorption has a great effect on strength.

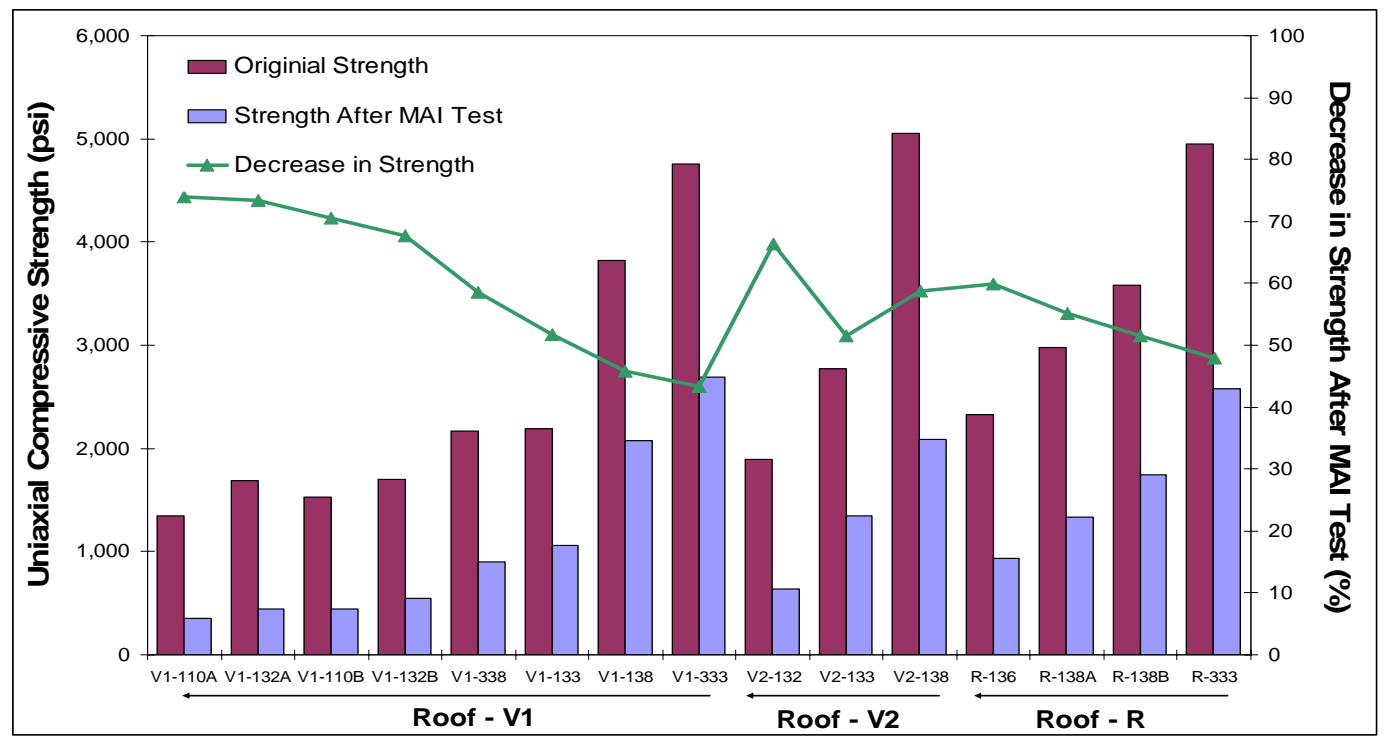

Figure 4.22: Effect of humidity on strength 
Correlations between the test results are also made. The relationships between uniaxial compressive strength, slake durability index (second cycle), moisture activity index, original water content, weatherability index, final vertical swelling strain and decrease in strength due to relative humidity changes are illustrated in the set of graphs in Figure 4.23 (the weatherability index of the shale type 110 is considered as an outlier).

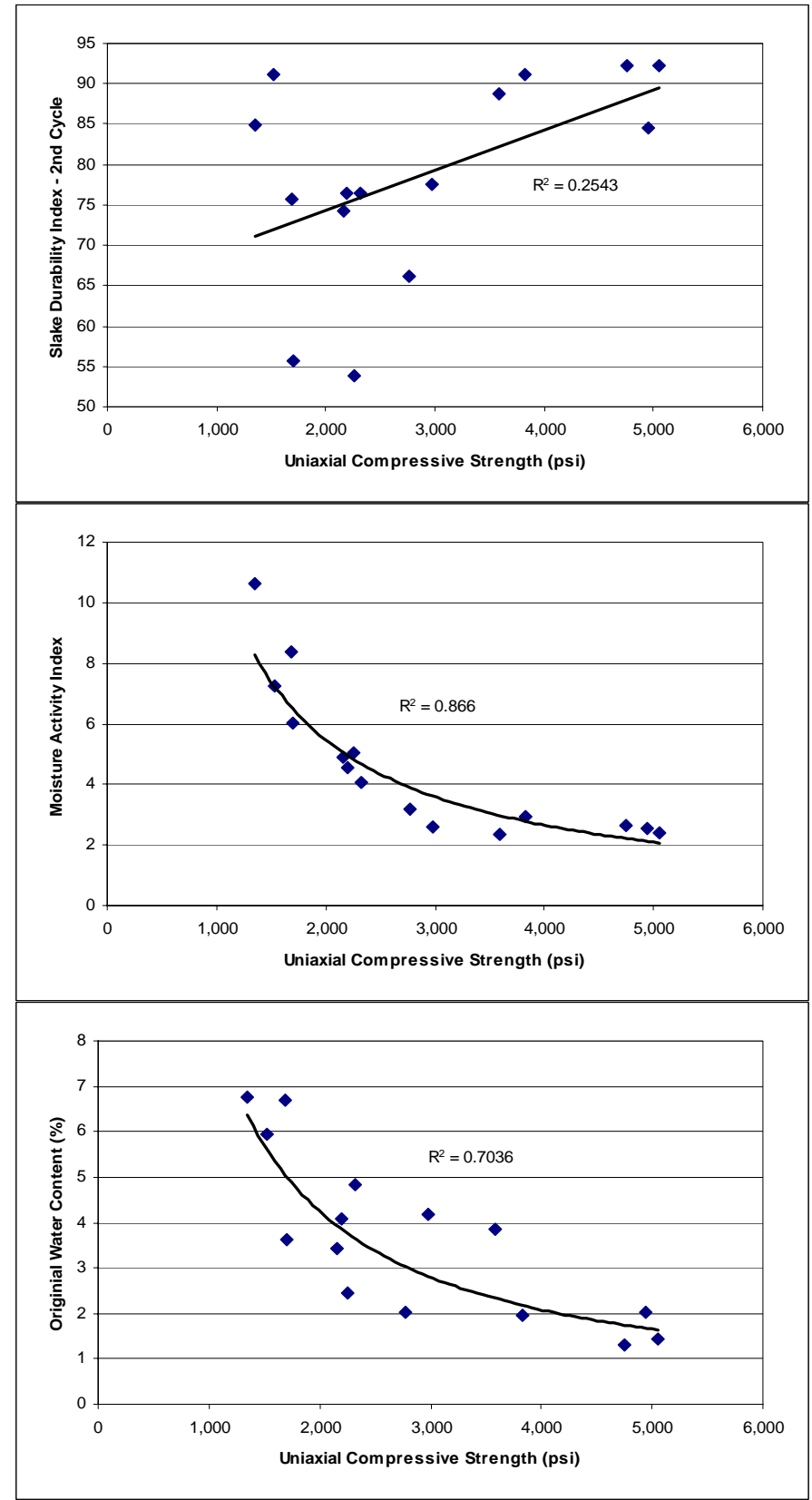




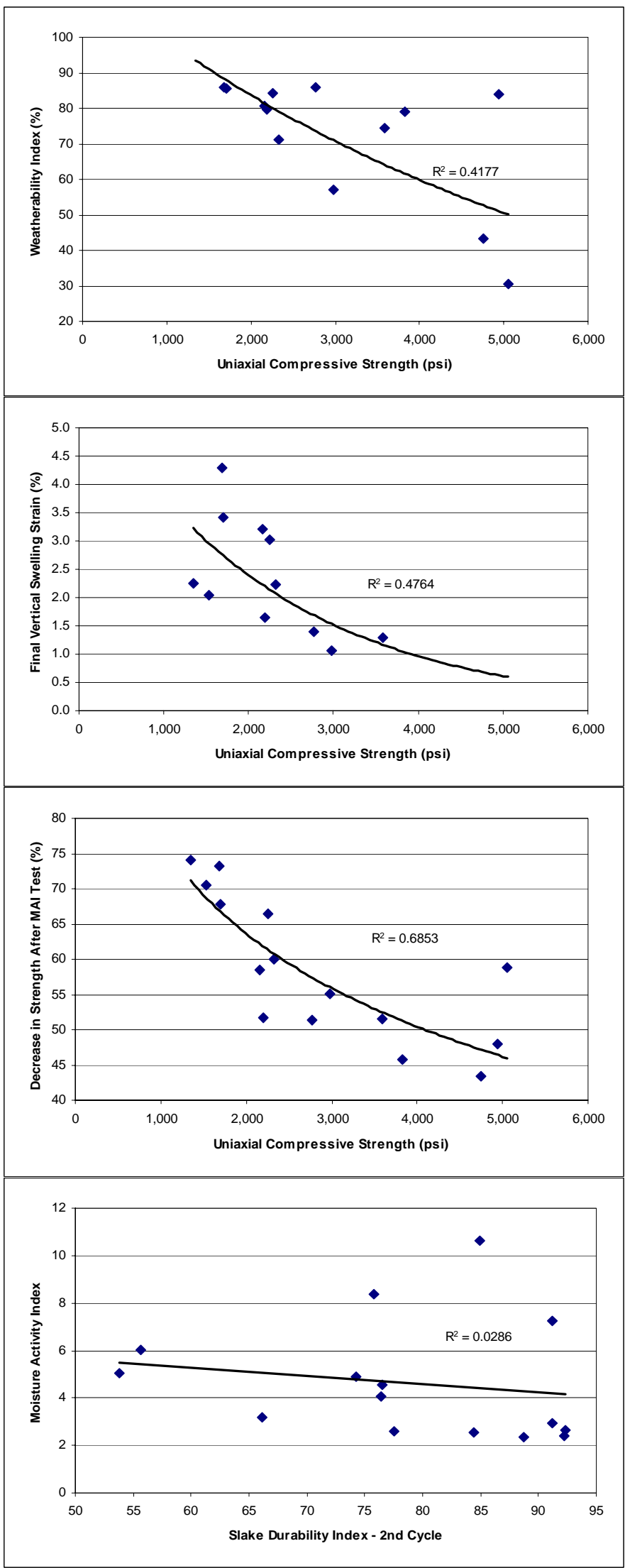




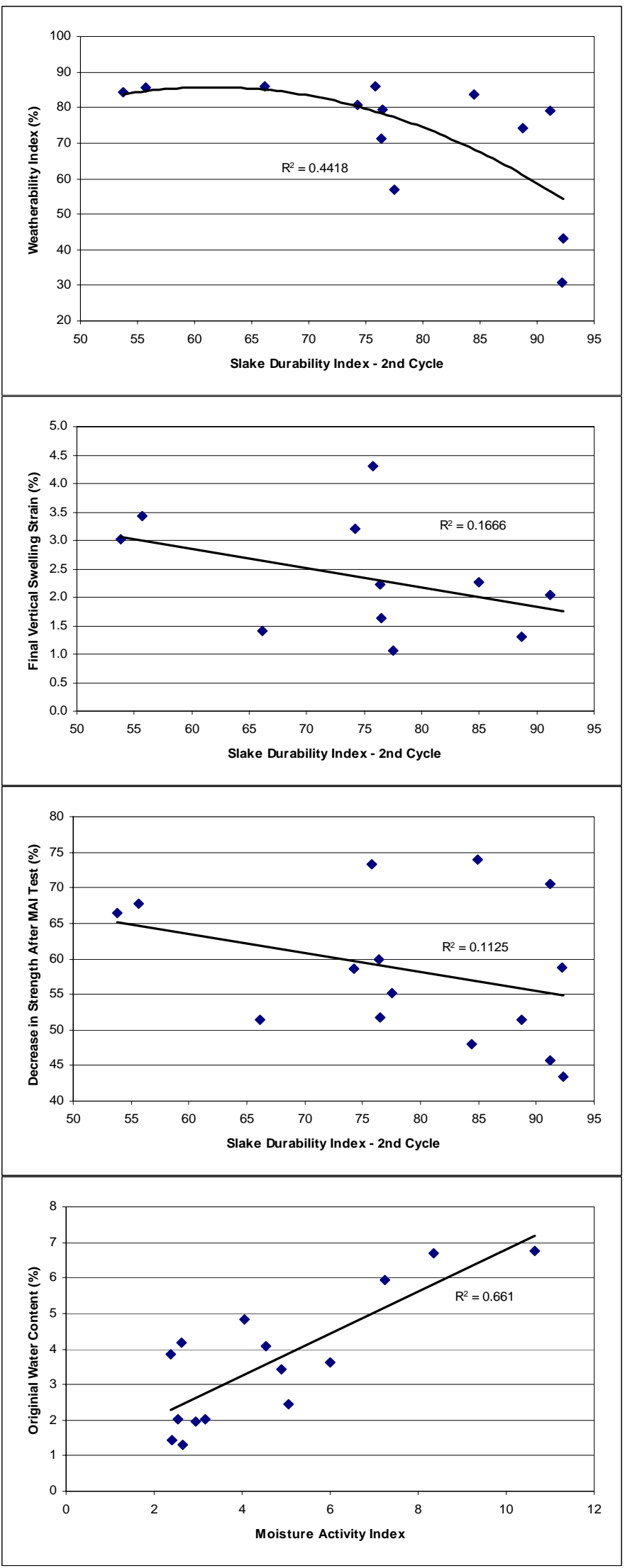



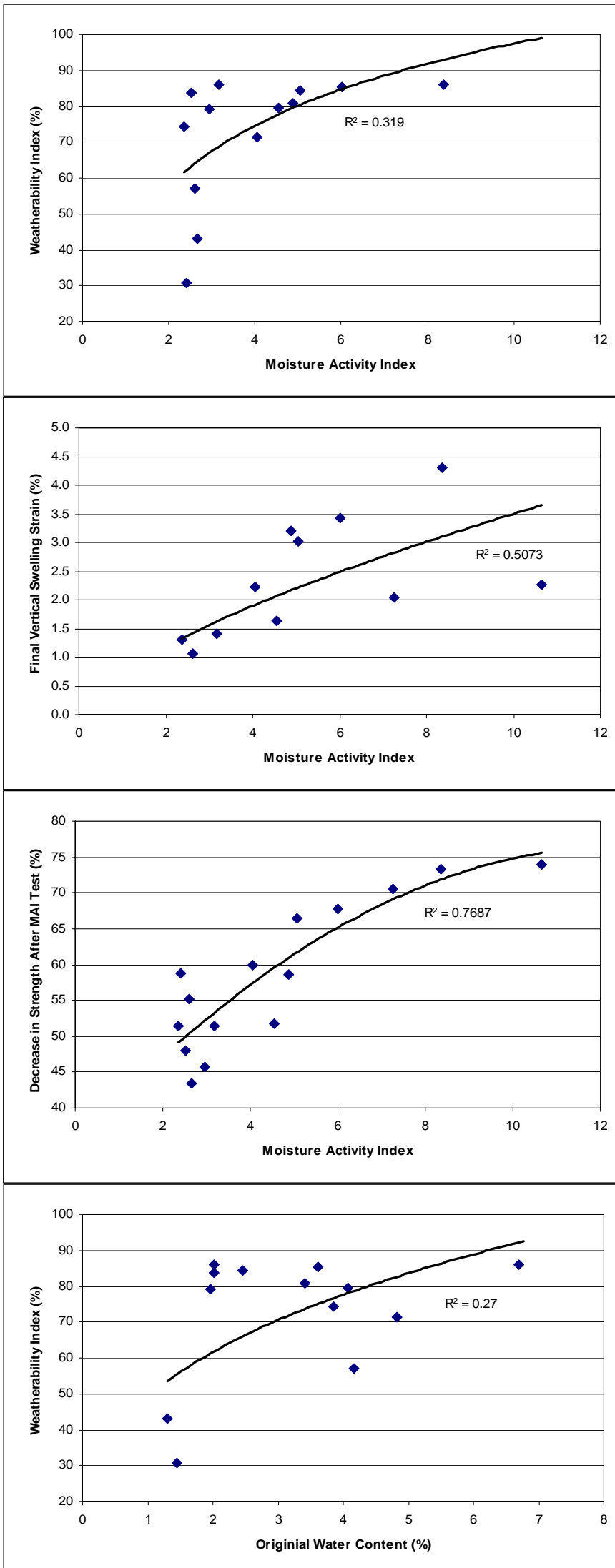

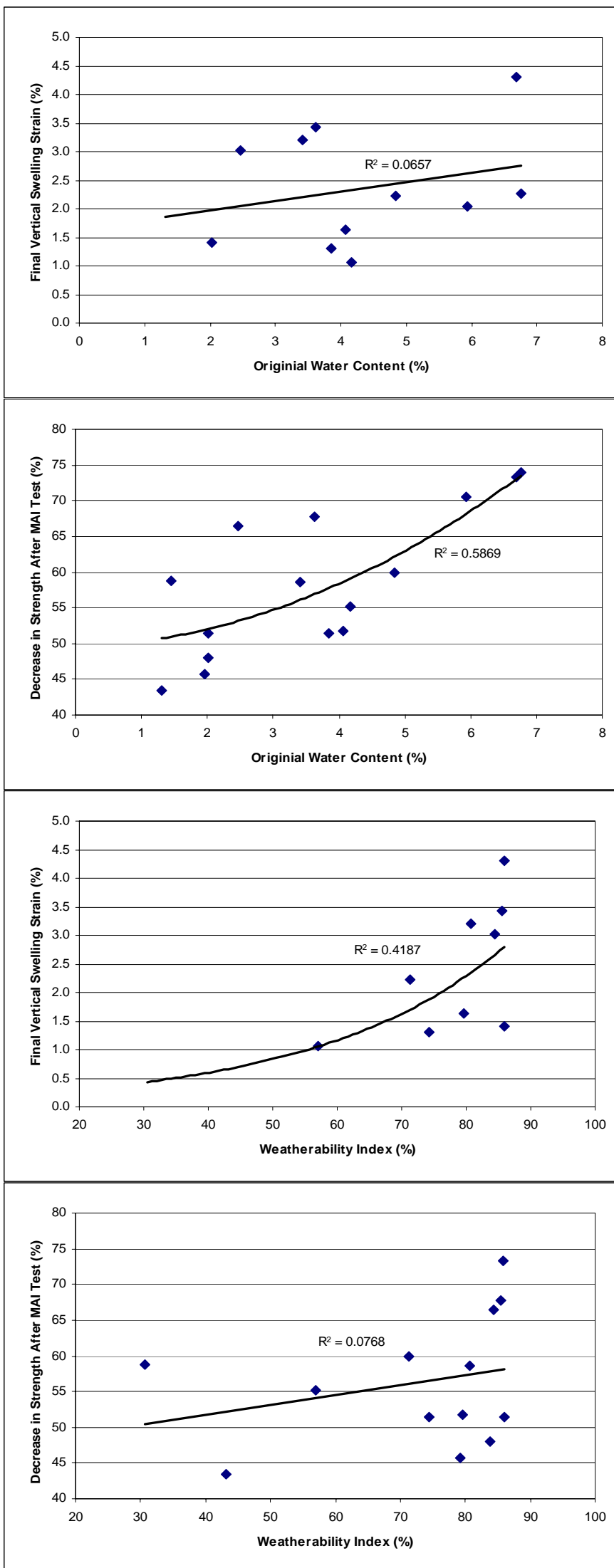


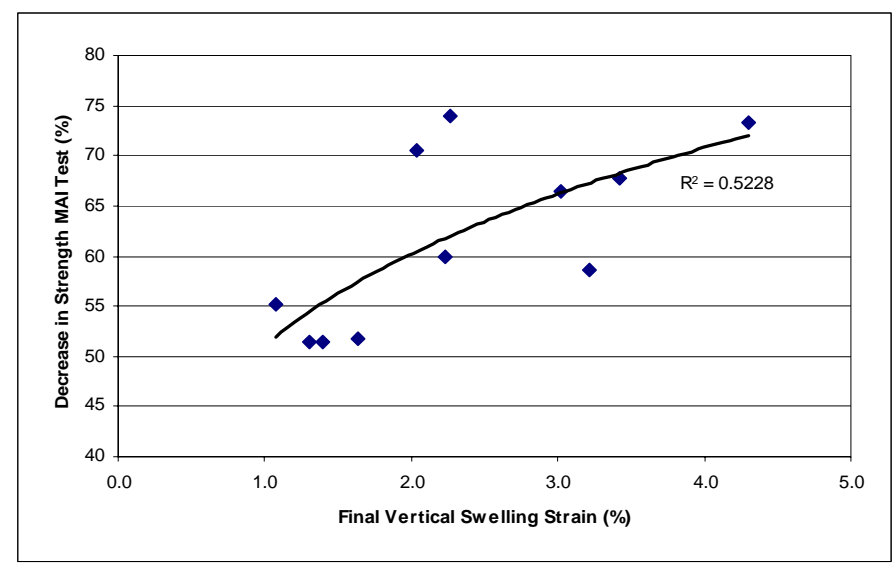

Figure 4.23: Set of correlation figures

A very good correlation $\left(R^{2}=0.866\right)$ is found between the moisture activity index and axial strength of these shales. These properties are inversely proportional with each other. Also, as the water content decreases, the strength of the shales increases. It is clearly seen that the percent decrease in strength after MAI test is also inversely proportional to the original strength of shales $\left(R^{2}=0.6853\right)$. It may also be said that strength is inversely proportional to the weatherability index $\left(R^{2}=\right.$ $0.4177)$ and swelling strain $\left(R^{2}=0.4764\right)$.

As it was expected, there is a good correlation between the moisture activity index and original water content $\left(R^{2}=0.661\right)$. These properties are directly proportional with each other. Moreover, as the moisture activity index increases, the swelling strain increases, and the strength decreases. These correlations can be explained as follows; the moisture susceptible (high moisture activity index) shales absorb more water, so their original water content is high. Then, the higher the water absorption is, the more swelling (expansion) occurs. As the rock expands more, cracks may occur inside and these cracks weaken the rock itself. Therefore, the strength decreases with the high moisture absorption.

On the other hand, it is observed that the decrease in strength after the MAI test is directly proportional with original water content and vertical swelling strain. This is just because of the higher the water absorption, the higher the swelling and the more decrease in the strength of the shales.

It is more difficult to make a positive conclusion about the relationship between the weatherability index and the other properties due to the inconsistency 
of the results of the weatherability test (very low $R^{2}$ values). As mentioned in the previous section, the weatherability of the shale type 110 is extremely low compared to the other shale types. This result was unexpected and it might come up because this rock type (carbonaceous shale) includes coal particles. Therefore, these values can be assumed as outliers and they may not be considered in the correlation analysis. Although there are some exceptions, it may be said that the higher the moisture activity index is, the higher the weatherability index and the higher the swelling strain are. However, this conclusion can hardly be drawn but it is what we expected to see.

No correlations were found between the slake durability index and the other properties because the slake durability index test did not give distinguished results between the shale types (very low $\mathrm{R}^{2}$ values). However, it still may be assumed that weatherability and slake durability indices are inversely proportional with each other according to the results of this study. 


\section{CHAPTER 5: DESIGN CONSIDERATIONS}

Shales in the mine roof deteriorate due to their high moisture absorption, weak strength, high potential of swelling, low durability, and high weatherability as discussed in the previous chapters. This situation causes difficulties in ventilation, increased cost of roof support, reduced safety, and delays in production, and ultimately increased cost of mining. Many roof falls occur due to the weathering behavior of shales. Cutter roof and skin roof failures are likely to occur in weak shale strata because of their low compressive and shear strength, high moisture sensitivity and high weatherability. Moreover, massive roof failures after mining are also common in these types of weak shale roofs due to their time dependent behavior.

It is very crucial for a design engineer to understand shale behavior and to solve the problems that are caused by weathering and high moisture absorption of shales. Hence, this chapter discusses mine and support design considerations based on the test results. Also, recommendations to prevent ground control problems are

given. It is very important to determine the safest and the most economical solution for shale roof strata control. Throughout ground control history, numerous attempts were made to solve the weathering problem of weak shale roof strata.

To control the shale deterioration, stable or low humidity levels should be established in the mine atmosphere. One way to control the humidity is to treat the mine atmosphere with some kind of tempering or conditioning or humidification systems. One common method is to use conditioning chambers due to its simplicity and relatively low cost. They are also called tempering entries, tempering chambers or cooling entries. The tempering entries are usually the areas of old works that the intake air is allowed to course through at fairly low velocities. This brings the air to equilibrium before being sent to more critical areas of the mine. Although deterioration in the conditioning chambers is expected, its effect on production at least is minimized [20]. Tempering chambers could be utilized to condense moisture from high temperature-high humidity intake air, thereby reducing the moisture 
content of the air in the working areas of the mine. The tempering chamber would only be needed during summer months, when the moisture level of the atmosphere is high. On the other hand, a humidification system could serve the same purpose, but would work essentially opposite to the tempering chamber and be used in the winter [28].

A very good and successful example of using conditioners was found in a U.S. Midwest underground coal mine, where two air conditioners were installed in 1998 to reduce the roof support and clean up cost. These conditioners were operated from April to October at a temperature of $60^{\circ} \mathrm{F}$ to decrease the moisture in the mine air. Immediate improvements in the roof conditions were observed. Also, it was economically a good decision for this coal mine.

Another solution to this problem is to cover the rock surface with a sealant to protect it from humidity changes. Some artificial sealants such as shotcrete, gunite, tar and polymeric sealants have been applied to the mine roofs. Although, they are very good at protecting the roof from deterioration, it is too expensive to install them everywhere. Therefore, it is suggested that these sealants should be employed in critical locations; haulageways, near shaft bottoms and the locations where massive roof failures are expected.

Leaving a few inches of coal as a sealant at the roof is another technique to solve the weak shale deterioration. This seems to be a good idea and some applications were done in the Pittsburgh Seam. However, the coal section left can sag and fall away after mining. But if the coal seam is thin, this may not be feasible due to the minimum height for operating equipment. Also, this is not a permanent solution for this problem. Another possibility is to remove all the problem strata in critical locations and major entries, if the stratum is not too thick.

Installing wire meshes on the critical points of the shale roof would be very useful for safety precautions. This could protect mine workers from small scale roof falls and create a better and a safer working environment.

Time is also another crucial point in preventing roof problems. Shale roof strata should be immediately sealed and reinforced, if a supporting technique is to be applied. The objective should be to cut the contact between the shales and air as soon as possible. 
The correct roof bolt selection is very crucial to prevent roof falls among the weathered strata. It is sometimes observed in coal mines having moisture sensitive roof that the height of the roof fall equals to the bolt length. This happens due to the moisture migration along the hole to the anchor point [30]. The decrease in the efficiency of the roof bolts due to the moisture was recorded by Oitto [31]. It was found that bolt load dropped or increased 2000-3000 lbs throughout the observation. This could happen because of the degradation of anchor point, swelling or shirking pressures at the bearing plates.

Mechanical bolts are not recommended in supporting moisture sensitive shale roofs because moisture penetrates into the space between the bolt and rock and affects shale strata through the bolt length. As mentioned in the previous chapters, shales absorb moisture and can swell around the bolt hole and increase the load on the bolt such that it may exceed the anchorage capacity of the bolt. Besides, in the winter time, when moisture leaves the rock, the shale can shrink and the contact between the rock and bolt can disappear. Therefore, fully grouted resin bolts are recommended to support this kind of moisture sensitive strata. Resin bolts are also recommended to prevent moisture migration into the rock.

Laboratory tests such as the ones that were used in this study can give information about the shale behavior before doing engineering designs. Therefore, more careful and detailed experiments and analysis should be made in the case of serious ground control problems due to weak and weathered roof. For instance, the swelling laboratory measurements give a good indication of shale deterioration. However, these tests are too complicated and costly for routine use. More simple tests, such as unconfined swelling tests, can be applied since they are easier (but unfortunately they are still time consuming). A database of shale swelling strains can be created and tolerable strain values can be found in the future to help with design considerations. Applying weatherability, moisture content determination and point load tests would give a fast and easy idea about the weathering and strength of the shales. Also, the moisture activity index test is strongly recommended for analyzing the weak shale moisture sensitivity. A new rock durability classification is needed to instead of the available durability tests. Durability is one of the most important characteristics of shales and more efforts should be made to analyze the shale durability. A good classification would help the design engineers to classify shales more accurately and take precautions if they face with non-durable rock strata. 
As mentioned in the previous chapters, there is a strong correlation between the water content and strength of shales. Even a small decrease in moisture levels can cause significant changes in the rock strength. Therefore, while applying rock mechanics tests to determine the mechanical properties of shales, the natural water content of the rock should definitely be preserved. Otherwise, the obtained values would be inaccurate and not be representative and they should not be used in engineering designs. This step is generally mentioned in all standard books. However, usually the laboratory technicians do not pay attention to this vital step while testing shales. It is recommended to seal the shale samples very carefully and test them immediately after they are taken out from the site. The immediate moisture loss in shales was tested at room atmosphere and Figure 5.1 shows the test results. It is clearly seen that shale samples lose moisture very quickly, especially during the first day where the amount loss is very significant. Therefore, the mechanical tests should be immediately done after the samples are taken out from the sealed core boxes.

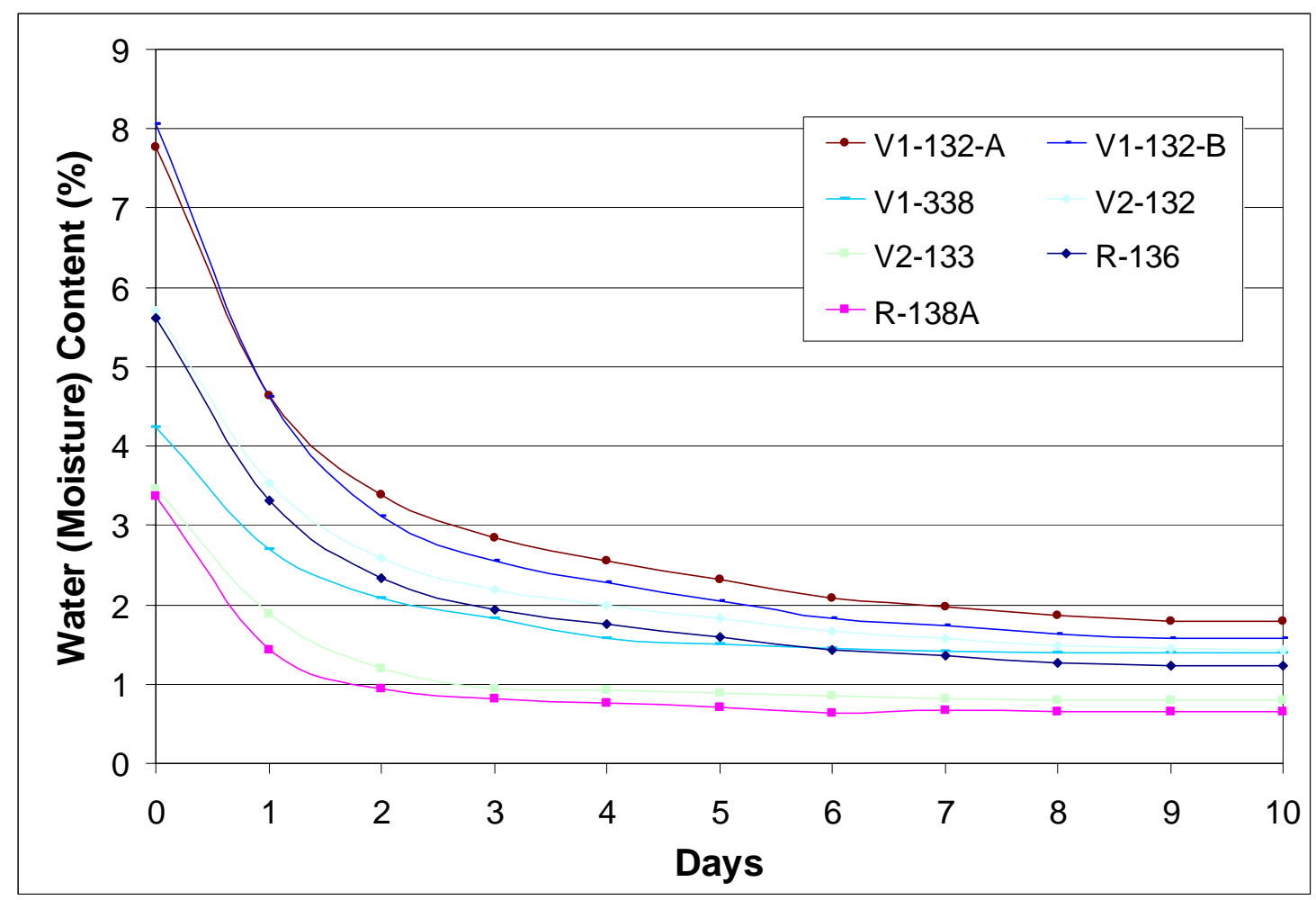

Figure 5.1: Moisture loss of the shale samples subjected to room atmosphere 
Furthermore, if the sample preparation steps such as cutting and grinding are needed before doing the rock mechanic tests, it is suggested to use dry processes (dry cutting and dry grinding) instead of the usual wet ones. Dry sample preparation could cause extreme amount of dust but by using masks and providing a good ventilation system in the laboratory, they can be safely applied. Dry cutting and grinding would also make sample preparation easier since there is no use of water that could cause shales to disintegrate while preparing the specimen.

Besides, immediately after drilling the rock cores that are going to be tested, it is very useful to determine the rock properties by doing rock classifications such as RQD, RMR and CMRR, and also give Ferm Numbers to the rocks and take pictures of them. These steps should be done on the drilling site before sending the samples to the laboratories. Otherwise, shale samples could alter due to moisture and temperature difference and some cracks could occur during travel. Moreover, it would be very useful to do point load strength tests on the drilling site, after taking the cores out to the surface. In this way, the natural moisture content of the rock would be preserved.

If a mining engineer suspects a seasonal change in the roof conditions, he or she should determine the number of roof falls throughout the months of the year and figure out which season has more ground control problems. Then, temperature and humidity levels in the mine atmosphere should be measured frequently to determine the worse season's weather conditions. Finally, the use of one of the solutions described above could be used.

Unfortunately, none of the recommendations that are discussed above can completely eliminate the moisture and weathering effects on shale strata. Thus, more research should be conducted to solve this problem. 


\section{CHAPTER 6: CONCLUSIONS}

Weak shale roof problems are common situations that are observed in underground coal mines. Mining and geotechnical engineers should be aware of these problems and precautions should be taken in order to provide safe, efficient and productive mining. However, these problems are still not well understood and coal miners are having difficulties when the roof consists of weak and weathered shale strata.

Many roof falls and accidents occur due to the shale strata in coal mines. Serious examples of this situation were found in two underground coal mines, Mine $V$ and Mine $\mathrm{R}$, located in the Illinois coal basin. Previous research and statistical data showed that Mine $\mathrm{V}$ has more roof falls and more serious ground control problems than Mine R. Core samples from three drill holes (V1, V2 and R) were tested in the laboratory and the summary of the entire test results are given in Table 6.1. The following important conclusions were made from the results:

- The point load test, moisture activity index test, and water (moisture) content determination test showed that immediate roof shales from Hole V1 are extremely weak and sensitive to moisture. This may show that some parts of Mine $\mathrm{V}$ have very serious ground control problems and extreme care should be taken at these locations in order to prevent roof falls.

- The slake durability indices of roof shales from Mine $R$ are always greater than 75 and they have a higher durability than the roof shales from Mine $V$. Sometimes, it was hard to classify these shales with the help of the slake durability indices due to the close results. Therefore, this study also agrees with most of the research about shale classification that the standard test method to determine the slake durability index should be improved or renewed. 
- The weatherability index test showed that shales from Mine V with 132 Ferm Number have very high weatherability indices and these shales almost entirely deteriorated from the weathering effect. Also, it was observed from this test that Mine $\mathrm{V}$ has very sensitive immediate roof rocks to weathering compared to the roof rocks of other coal mines in the U.S.

- Lateral (parallel to bedding) swelling is insignificant for these shale types. In this analysis, vertical swelling strain of the tested shale types ranges from $1.07 \%$ to $4.30 \%$. The roof shales from Mine $V$ with 132 and 338 Ferm Numbers has vertical swellings greater than 3\%, which can be considered significant expansions.

- Problem minerals such as montmorillonite, smectite or vermiculite were not present in the shales that were scanned by the x-ray diffraction test. On the other hand, illite, muscovite and siderite were found instead of these minerals and they might be reason of the weakness of these shales. Actually, siderite was only present in the immediate roof of Mine V.

- As a result, it was proven that Mine $\mathrm{V}$ has weaker, less durable, higher moisture sensitive and more weatherable roof rocks than Mine R. Rocks with a Ferm Number of 132 have especially low slake durability index values, weak strength, high weatherability and high vertical swelling strain that can reach up to $4.30 \%$. It is certain that this shale stratum causes many ground control problems due to its weak properties.

- Despite their weak strength and high moisture sensitivity, rocks with a Ferm Number of 110 have high durability and they are not affected by the wetting and drying cycles.

- Good correlations were found between the location of the sample and the strength, moisture activity index and water content. As the distance between the coal and the roof rock increases, the strength of the shales increases, the moisture activity index and water content decrease.

- The moisture activity index is directly proportional to swelling strain and inversely proportional to strength. The moisture susceptible shales absorb more water, so their original water content is high. The greater the water 
absorption, the more swelling that occurs. If the rock expands too much, cracks may occur inside and these cracks weaken the rock itself.

- The moisture activity and weatherability indices, and swelling strain values are good ways of expressing the shale behavior. Therefore, if a weak and moisture sensitive shale roof has to be analyzed, the moisture activity index, weatherability, and swelling strain tests should be performed to determine moisture sensitivity, durability and swelling behaviors of weak rocks. Also, it was recommended to apply point load test on the drilling site, after taking the cores out to the surface.

Mine support and design considerations based on these test results were discussed and recommendations to prevent ground control problems were also given. Possible solutions for the ground control problems of the moisture sensitive, weak and weathered shale roofs are: using conditioning chambers or artificial sealants, leaving a few inches of coal, removing all the problem strata, and installing fully grouted resin bolts and wire mesh. The humidity levels should be kept constant in mines and the contact between the shale roof and the mine atmosphere should be cut as soon as possible. It was suggested to do very detailed analyses for the shale roof strata. The laboratory tests described in this study were also strongly recommended to understand the shale behavior. 
Table 6.1. Summary of the test results

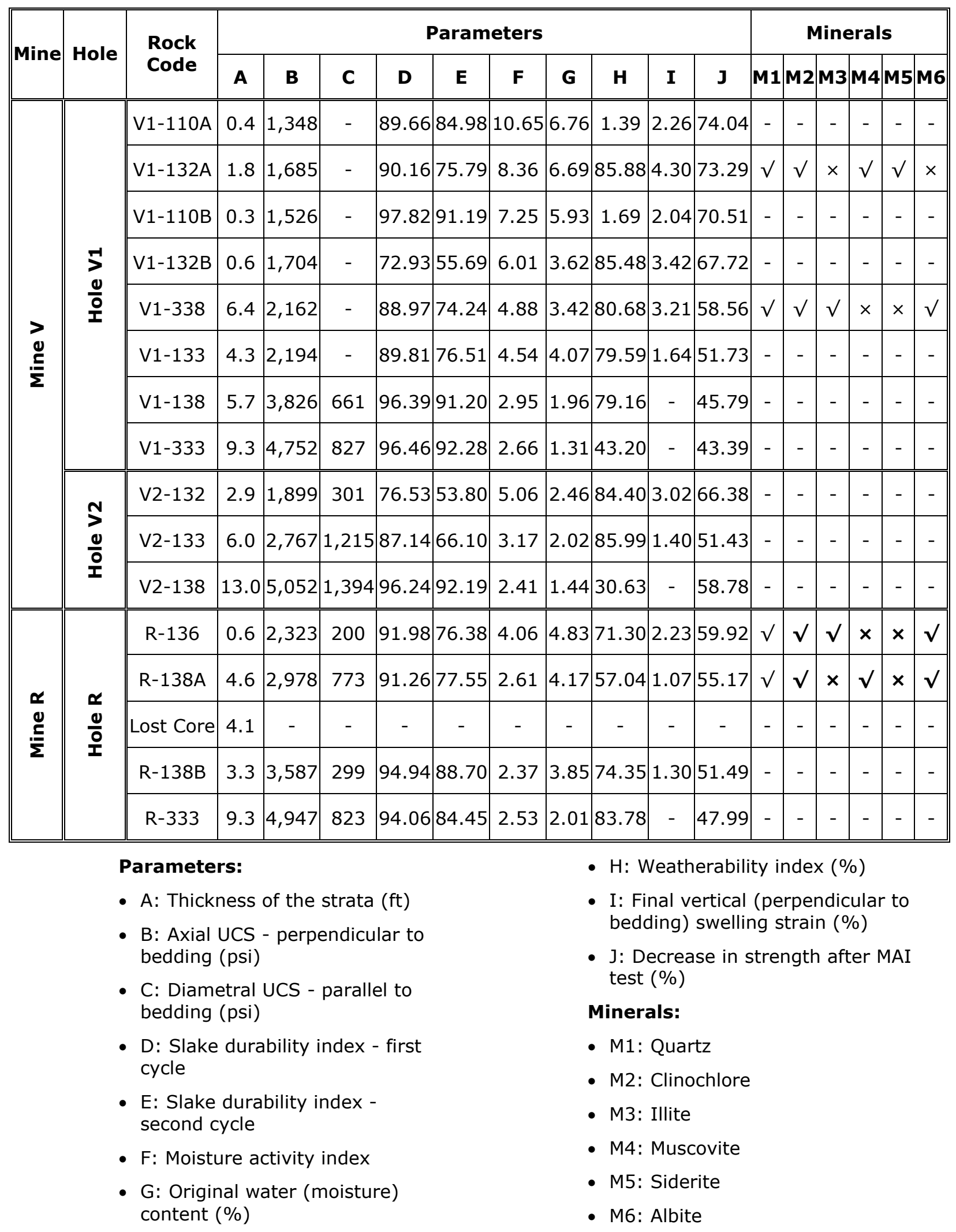




\section{REFERENCES}

[1] ISRM, 1981, Basic Geotechnical Description of Rock Masses, ISRM Commission on Classification of Rocks and Rock Masses. Int. J. Rock Mech. Min. Sci. \& Geomech. Abstr. 18, pp. 85-110.

[2] Seedsman, R. W., Characterizing Clay Shales, Comprehensive Rock Engineering, Vol. 3, 1993, pp. 151-165.

[3] Yagiz, S., Overview of Classification and Engineering Properties of Shales for Design Considerations. Proc. of Construction Institute sessions at the ASCE 2001 Civil Engineering Conference, October 10-13, 2001, Houston, Texas/sponsored by American Society of Civil Engineers, the Construction Institute, pp. 156-165.

[4] Holland, C. T., Mineral Content, A Factor in Weathering of Mine Roof, January, 1956.

[5] Tangchawal, S., 1988, Engineering Properties and Clay Mineralogy of Illinois Coal-Mine Roof Shales and Underclays, Ph.D. Dissertation, University of Missouri-Rolla, pp. 5-7.

[6] Peng, S. S., Zhang, Y., Morsy, K., Gadde, M. and Han, J., Analysis of Roof Stability and Roof Supporting Systems for Vermillion Grove Mine, Ridge Farm, IL, January 2004, pp. 3-4.

[7] Molinda, G., Mark, C. and Burke, L., Trip Report, Black Beauty Coal Co., February 11-13, 2004. 
[8] Mark, C., Molinda, G. and Burke, L., Preventing Falls of Ground in Coal Mines with Exceptionally Low-Strength Roof: Two Case Studies, Proc. $22^{\text {nd }}$ Int. Conf. On Ground Control in Mining, August 2003, Morgantown, WV, pp. 220-227.

[9] Oliveira, R., Weak Rock Materials, The Engineering Geology of Weak Rock, Engineering Geology Special Publication No. 8, Balkema, Rotterdam, 1993, pp. 7-11.

[10] Rocha, M. 1977, Alguns problemas relativos a mecanica das rochas dos materias de baiza resistencia. Memory n 491, LNEC, Lisboa.

[11] Dobereiner, L., Construction problems related to excavation on soft rock, General Report, Discussion Session 5, $12^{\text {th }}$ Cong. ISSMFE, 4. Rio Janeiro: Balkema, 1989.

[12] Zhang, Y., Han, J., Heasley, K., Syd, S. S. and Padgett, P. L., Geo-mechanical Property and Failure of Weak Roof Shales in Coal Mines, Proc. $23^{\text {rd }}$ Int. Conf. On Ground Control in Mining, August 2003, Morgantown, WV, pp. 228-234.

[13] Huang S. L., Aughenbaugh, N. B. and Rockaway, J. D., Swelling pressure studies of shales, Int. J. Rock Mech. Min. Sci. \& Geomech. Abstr. 23, 1986, pp. 371-377.

[14] Huang S. L., Aughenbaugh, N. B. and Rockaway, J. D., Characterization of swelling potential of shale strata, Proc. $27^{\text {th }}$ U.S. Symp. Rock Mech. Univ. of Alabama, 1986, pp. 69-76.

[15] Huang S. L., Speck, R. C. and Wang, Z., The Temperature Effect on Swelling of Shales Under Cyclic Wetting and Drying, Int. J. Rock Mech. Min, Sci. \& Geomech. Abstr. Vol. 32, No 3, 1995, pp. 227-236.

[16] Holtz, W. G. and Gibbs, H. J., Engineering Properties of Expansive Clays, American Society of Civil Engineers, Vol. 121, 1954, Paper No. 2814.

[17] Meade, R.H., Removal of Water and Rearrangement of Particle during the Composition of Clayey Sediments-Review, U.S. Geological Survey, Professional Paper, 1964, 497B. 
[18] Aughenbaugh, N. B., Effect of moisture in shale, $23^{\text {rd }}$ Annual Soil Mechanics and Foundation Engineering Conf. ASCE Geotechnical Division, Kansas City, 1974.

[19] Singh, M. M. and Cummings, R. A., Predicting Moisture-Induced Deterioration of Shales, Proc. of the Fifth Congress of the International Society for Rock Mechanics, Melbourne, Australia, 1983, pp. E87-E95.

[20] Singh, M. M., Cummings, R. A. and Moebs, N.N., Effect of Moisture on the Deterioration of Coal Mine Roof Shales, Technical Note, Mining Engineering, March 1983.

[21] Unrug, K. F., Weatherability Test of Rock for Underground Mines, Proc. $16^{\text {th }}$ Int. Conf. On Ground Control in Mining, August 1997, Morgantown, WV, pp. 259266.

[22] Aughenbaugh, N. B., Effects of Humidity on Ground Control in Mining and Tunneling, Mini Symposium, SME AIME, Littleton, CO, February 1981, pp. 1520.

[23] Duncan, N., Dunne, M.H. and Petty, S., "Swelling Characteristics of Rocks", Water Power, May 1968, pp. 185-192.

[24] Olivier, H. J., "A New Engineering-Geological Rock Durability Classification", Engineering Geology, Vol. 14, 1979, pp. 225-279.

[25] Hopkins, C. T. and Deen R. C., Identification of Shales, Geotechnical Testing Journal, American Society for Testing and Materials, 1984, pp. 10-18.

[26] Mielenz, R. C. and King, M. E., Physical-Chemical Properties and Engineering Performance of Clays, Bull. 169, Clay and Clay Technology, (1955) pp. 196254.

[27] Van Eeckhout, E. M., The Mechanisms of Strength Reduction Due to Moisture in Coal Mine Shales, Int. J. Rock Mech. Min Sci. and Geomech. Abstr., Vol. 13, 1976, pp. 61-67.

[28] Haynes, C. D., Effects of Temperature and Humidity Variations on the Stability of Coal Mine Roof Rocks, USBM Contract Report H0122111, June 1975. 
[29] Van Eeckhout, E. M. and Peng, S. S., The Effect of Humidity on the Compliances of Coal Mine Shales, Int. J. Rock. Mech. Min. Sci. \& Abstr. Vol. 12, 1975, pp. 335-340.

[30] Chugh, Y. P. and Missavage, R. A., Effects of Moisture on Strata Control in Coal Mines, 1980, pp. 70-88.

[31] Oitto, R., Zona A. and Stears, J., How Bearing Plates Affect Roof Bolt Performance, Coal Mining and Processing, Vol. 7, No. 12, 1970.

[32] Koncagul, E. C. and Santi, P.M., Predicting the Unconfined Compressive Strength of the Breathitt Shale Using Slake Durability, Shore Hardness and Rock Structural Properties, Int. J. Rock Mech. \& Min. Sci., Vol. 36, 1999, pp. 139-153.

[33] ASTM Standards, D 5731-95, Standard Test Method for Determination of the Point Load Strength Index of Rock, Annual Book of ASTM Standards, 2000, Vol. 04.08., pp. 1442-1448.

[34] Rusnak, J. and Mark, C., Using the Point Load Test to Determine the Uniaxial Compressive Strength of Coal Measure Rock, Proc. $19^{\text {th }}$ Int. Conf. On Ground Control in Mining, August 2000, Morgantown, WV, pp. 362-371.

[35] ASTM Standards, D 4644-95, Standard Test Method for Slake Durability of Shales and Similar Weak Rocks, Annual Book of ASTM Standards, 2000, Vol. 04.08., pp. 778-780.

[36] Ferm, J. C. and Weisenfluh, G. A., Cored Rocks in the Southern Appalachian Coalfields, U.S. Bureau of Mines Contract No.H0230028 and No. J0188115, Library of Congress \# 81-51290, 1981, 93 pp.

[37] ASTM Standards, D 2216-98, Standard Test Method for Laboratory Determination of Water (Moisture) Content of Soil and Rock by Mass, Annual Book of ASTM Standards, 2000, Vol. 04.08., pp. 208-212.

[38] ISRM, Suggested Method for Determination of the Swelling Strain Developed in an Unconfined Rock Specimen, ISRM Commission on Standardization of 
Laboratory and Field Tests, Int. J. Rock Mech. Min. Sci. \& Geomech. Abstr., Vol 16, No. 2, 1979, pp 141-156.

[39] Tangchawal, S., 1988, Engineering Properties and Clay Mineralogy of Illinois Coal-Mine Roof Shales and Underclays, Ph.D. Dissertation, University of Missouri-Rolla, pp 68-69.

[40] Grim, R. E., International Series in the Earth Sciences, Applied Clay Mineralogy, New York, McGraw-Hill, 1962 pp. 147-148.

[41] Ries, H., Clays, Their Occurrence, Properties, and Uses, with Especial Reference to Those of the United States and Canada, Third Edition, New York, J. Wiley \& Sons, London, Chapman \& Hall, 1927, pp. 87-92.

[42] Brown, E., T., Rock Characterization, Testing and Monitoring - ISRM Suggested Methods, Pergamon, Oxford, 1981, pp. 171-183. 


\section{APPENDIX A}

The failure load $(P)$ is calculated from the ram pressure ( $R$, reading from the pressure gauge in psi) as follows:

$$
P=R \times \frac{\pi D_{R}^{2}}{4}
$$

where $D_{R}=1.5$ in, which is the diameter of the ram.

Table A.1. Point load strength index test data

\begin{tabular}{|c|c|c|c|c|c|c|c|c|c|c|c|c|c|}
\hline $\begin{array}{c}\text { Sample } \\
\text { Name }\end{array}$ & Hole & $\begin{array}{l}\text { Depth } \\
\text { (ft) }\end{array}$ & $\begin{array}{l}\text { Ax } \\
\text { or } \\
\text { Dia }\end{array}$ & $\begin{array}{l}W \\
\text { (in) }\end{array}$ & $\begin{array}{c}D \\
\text { (in) }\end{array}$ & $\begin{array}{c}D_{e} \\
\text { (in) }\end{array}$ & $\begin{array}{c}R \\
(\mathrm{psi})\end{array}$ & $\begin{array}{c}P \\
\text { (Ibs) }\end{array}$ & $\begin{array}{c}I_{s} \\
(\mathrm{psi})\end{array}$ & $\mathrm{F}$ & $\begin{array}{l}I_{s(50)} \\
(\mathrm{psi})\end{array}$ & $\begin{array}{c}\delta_{U C} \\
(\mathrm{psi})\end{array}$ & $\begin{array}{c}\text { Ferm } \\
\text { No }\end{array}$ \\
\hline$A$ & $\mathrm{~V} 2$ & 181.1 & $A$ & 1.405 & 2.990 & 2.313 & 800 & 1414 & 264 & 1.08 & 284 & 5968 & 138 \\
\hline B & V2 & 181.3 & A & 1.032 & 2.990 & 1.982 & 500 & 884 & 225 & 1.00 & 226 & 4737 & 138 \\
\hline C & V2 & 182.8 & A & 1.005 & 2.990 & 1.956 & 550 & 972 & 254 & 1.00 & 253 & 5319 & 138 \\
\hline D & $\mathrm{V} 2$ & 182.9 & A & 1.030 & 2.990 & 1.980 & 450 & 795 & 203 & 1.00 & 203 & 4270 & 138 \\
\hline$E$ & V2 & 183 & A & 1.400 & 2.990 & 2.309 & 650 & 1149 & 216 & 1.07 & 232 & 4862 & 138 \\
\hline $\mathrm{F}$ & V2 & 184.6 & A & 0.995 & 2.990 & 1.946 & 400 & 707 & 187 & 0.99 & 186 & 3899 & 138 \\
\hline G & $\mathrm{V} 2$ & 184. & A & 0.997 & 2.990 & 1.948 & 350 & 619 & 163 & 1.00 & 162 & 3406 & 138 \\
\hline $\mathrm{H}$ & $\mathrm{V} 2$ & 185.9 & A & 0.990 & 2.990 & 1.941 & 550 & 972 & 258 & 0.99 & 256 & 5382 & 138 \\
\hline I & V2 & 187.9 & A & 1.275 & 2.990 & 2.203 & 800 & 1414 & 291 & 1.05 & 306 & 6434 & 138 \\
\hline J & $\mathrm{V} 2$ & 188 & A & 0.993 & 2.990 & 1.944 & 500 & 884 & 234 & 0.99 & 232 & 4881 & 138 \\
\hline K & V2 & 188.3 & A & 1.130 & 2.990 & 2.074 & 570 & 1007 & 234 & 1.02 & 240 & 5034 & 138 \\
\hline $\mathrm{L}$ & V2 & 188.4 & A & 1.275 & 2.990 & 2.203 & 800 & 1414 & 291 & 1.05 & 306 & 6434 & 138 \\
\hline- & V2 & 182.8 & D & - & 2.990 & 2.990 & 250 & 442 & 49 & 1.21 & 60 & 1253 & 138 \\
\hline - & V2 & 182.9 & D & - & 2.990 & 2.990 & 350 & 619 & 69 & 1.21 & 84 & 1754 & 138 \\
\hline- & V2 & 184.6 & D & - & 2.990 & 2.990 & 20 & 35 & 4 & 1.21 & 5 & 100 & 138 \\
\hline- & V2 & 18 & D & - & 2.990 & 2.990 & 39 & 689 & 77 & 1. & 93 & 1954 & 138 \\
\hline- & V2 & 188.3 & D & - & 2.990 & 2.990 & 310 & 548 & 61 & 1.21 & 74 & 1553 & 138 \\
\hline- & $\mathrm{V} 2$ & 188.4 & D & - & 2.990 & 2.990 & 350 & 619 & 69 & 1.21 & 84 & 1754 & 138 \\
\hline M & V2 & 190.1 & A & 1.150 & 2.990 & 2.092 & 650 & 1149 & 262 & 1.03 & 270 & 5663 & 133 \\
\hline $\mathrm{N}$ & V2 & 190.2 & A & 1.050 & 2.990 & 1.999 & 600 & 1060 & 265 & 1.01 & 267 & 5609 & 133 \\
\hline 0 & V2 & 192 & A & 1.200 & 2.990 & 2.137 & 500 & 884 & 193 & 1.04 & 201 & 4215 & 133 \\
\hline$P$ & V2 & 194.1 & A & 0.995 & 2.990 & 1.946 & 200 & 353 & 93 & 0.99 & 93 & 1949 & 133 \\
\hline $\mathrm{R}$ & V2 & 194.2 & A & 1.025 & 2.990 & 1.975 & 150 & 265 & 68 & 1.00 & 68 & 1429 & 133 \\
\hline S & V2 & 194.3 & A & 0.998 & 2.990 & 1.949 & 170 & 300 & 79 & 1.00 & 79 & 1653 & 133 \\
\hline
\end{tabular}




\begin{tabular}{|c|c|c|c|c|c|c|c|c|c|c|c|c|c|}
\hline $\mathrm{T}$ & V2 & 95.5 & 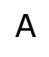 & .900 & 2.990 & 1.851 & 200 & 353 & 103 & 0.97 & 100 & 2107 & 133 \\
\hline$U$ & V2 & 195.9 & & 0.950 & 2.990 & 1.902 & 100 & 177 & 49 & 0.98 & 48 & 1010 & 13 \\
\hline V & V2 & 96.7 & & .900 & 2.990 & 1.851 & 120 & 212 & 62 & 0.97 & 60 & 1264 & 3 \\
\hline 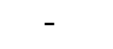 & V2 & 90.2 & & - & 2.990 & 2.990 & 00 & 1414 & 158 & .21 & 191 & 008 & 13. \\
\hline - & V2 & 92.1 & & - & .990 & 2.990 & .00 & 177 & 20 & .21 & 24 & 501 & 37. \\
\hline - & V2 & 94.1 & & - & 2.990 & 2.990 & 20 & 35 & 4 & 1.21 & 5 & 100 & \\
\hline - & V2 & 94.2 & & - & 2.990 & 2.990 & 50 & 88 & 10 & 1.21 & 12 & 251 & \\
\hline Y & V2 & 98.1 & & .350 & 990 & 2.267 & 500 & 884 & 172 & 1.07 & 183 & 3847 & \\
\hline Z & V2 & 199 & & 295 & .990 & 2.220 & 450 & 795 & 161 & 1.06 & 170 & 3576 & \\
\hline 1 & V2 & 199.4 & & 910 & .990 & 1.861 & 100 & 177 & 51 & 0.98 & 50 & .045 & 2. \\
\hline 2 & V2 & 99.5 & & 070 & .990 & 2.018 & 300 & 530 & 130 & 1.01 & 132 & 2764 & \\
\hline 3 & 12 & 201 & & 205 & .990 & 2.142 & 400 & 707 & 154 & 1.04 & 160 & 361 & \\
\hline 5 & V2 & 201.9 & & .905 & .990 & 1.856 & 150 & 265 & 77 & 0.97 & 75 & .574 & \\
\hline 6 & 12 & 202.2 & & .998 & .990 & 1.949 & 180 & 318 & 8 & 1.00 & 83 & 1750 & \\
\hline 7 & 12 & 202.3 & & 238 & .990 & 2.171 & 170 & 00 & $0^{4}$ & 1.05 & 67 & 399 & \\
\hline 8 & V2 & 202.7 & & .005 & .990 & 1.956 & 100 & 177 & 46 & 1.00 & 46 & 967 & \\
\hline - & V2 & 199.5 & & - & 2.990 & 2.990 & 20 & 35 & 4 & 1.21 & 5 & 100 & \\
\hline- & V2 & 202.1 & & - & 2.990 & 2.990 & 100 & 177 & 20 & 1.21 & 24 & 501 & \\
\hline$-\mathrm{V} 1$ & 1 & 234 & & 637 & 3.000 & 2.500 & 900 & 1590 & 254 & 1.11 & 283 & 5949 & \\
\hline$-\mathrm{V} 2$ & 1 & 234.9 & & 163 & .000 & 2.875 & 1000 & 767 & 21 & 1.19 & 254 & 325 & \\
\hline$-\mathrm{V} 3$ & 1 & 238.7 & & 967 & .000 & 2.741 & 950 & 1679 & 223 & 1.16 & 259 & 447 & \\
\hline $1-V 4$ & 1 & 238.9 & & .140 & .000 & 2.859 & 1050 & 1856 & 227 & 1.18 & 269 & 639 & \\
\hline -V5 & 1 & 240 & & 500 & .000 & 3.090 & 1200 & 2121 & 22 & 1.22 & 272 & 713 & \\
\hline$E$ & V1 & 236.7 & & 290 & 3.005 & 2. & 400 & 707 & 14 & 1.06 & & 76 & \\
\hline D & V1 & 236.8 & & 230 & 3.005 & 2. & 370 & 6 & 1 & 1. & 45 & 048 & \\
\hline C & 1 & 237 & & 331 & .005 & 2.257 & 450 & 795 & 1 & 1.06 & 66 & 487 & 3 \\
\hline B & V1 & 237.2 & & 311 & .005 & 2.240 & 510 & 901 & 180 & 1.06 & 190 & 999 & \\
\hline A & 11 & 237.4 & & 036 & 3.005 & 1.991 & 420 & 742 & 187 & 1.01 & 188 & 3952 & \\
\hline G & V1 & 241.2 & & 112 & 2.995 & 2.059 & 590 & 1043 & 24 & 1.02 & 51 & 269 & \\
\hline $\mathrm{F}$ & V1 & 241.3 & & 168 & 2.995 & & 700 & 1237 & 278 & 1. & 287 & 6018 & \\
\hline- & V1 & 237 & & - & 3.005 & & 150 & & 2 & & 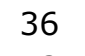 & 46 & \\
\hline- & V1 & 237.2 & & - & 3.005 & 5 & 180 & 318 & 3 & 1.21 & 3 & 95 & \\
\hline- & V1 & 237.3 & & - & 3.005 & 3. & 110 & 194 & 2 & 1.21 & 6 & 547 & \\
\hline- & V1 & 241.1 & & - & 2.995 & 2.995 & 200 & 353 & 3 & 1.21 & & 99 & \\
\hline- & V1 & 241.2 & & - & 2.995 & 2.995 & 190 & & & 1. & & 49 & \\
\hline J & V1 & 243.8 & & & 2.980 & & 500 & 884 & + & 1. & & 760 & \\
\hline I & V1 & 243.9 & & 3 & 2.980 & 2. & 700 & 1237 & 22 & 1.08 & 246 & 156 & \\
\hline $\mathrm{H}$ & V1 & 244 & $A$ & 5 & .980 & & 280 & 495 & 130 & 1.00 & 129 & 715 & \\
\hline $\mathrm{N}$ & V1 & 245 & & 162 & 2.997 & 2.106 & 440 & 778 & 175 & 1.03 & 181 & 3796 & \\
\hline M & V1 & 45 & & 021 & 2.997 & & 500 & 88 & & 1.00 & & 4768 & \\
\hline $\mathrm{L}$ & V1 & 2 & & & 2.997 & & 420 & & & 0 & & 058 & \\
\hline $\mathrm{K}$ & V1 & 245.3 & & & 2.997 & & 580 & 1025 & & 1.01 & & 5296 & \\
\hline $\mathrm{R}$ & V1 & 246.4 & $A$ & .310 & 2.995 & 2.235 & 420 & 742 & 149 & 1.06 & 157 & 3304 & \\
\hline$P$ & V1 & 246.5 & 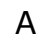 & .007 & 2.995 & 1.960 & 200 & 353 & 92 & 1.00 & 92 & 1929 & \\
\hline $\mathrm{O}$ & V1 & 246.6 & & .115 & 2.995 & 2.062 & 390 & 689 & 162 & 1.02 & 166 & 3476 & \\
\hline- & V1 & 243.8 & & - & 2.980 & 2.980 & 150 & 26 & 30 & 1.21 & 36 & 755 & \\
\hline- & V1 & 243.9 & D & - & 2.980 & 2.980 & 100 & 177 & & 1.21 & & 504 & \\
\hline- & V1 & 245 & D & - & 2.997 & 2.997 & 170 & 300 & 33 & 1.21 & 40 & 849 & \\
\hline - & V1 & 245.1 & D & - & 2.997 & 2.997 & 210 & 371 & 41 & 1.21 & 50 & 1048 & \\
\hline- & V1 & .2 & D & - & 997 & 2.997 & 205 & 362 & 40 & 1.21 & 49 & 1023 & \\
\hline
\end{tabular}




\begin{tabular}{|c|c|c|c|c|c|c|c|c|c|c|c|c|c|}
\hline- & 11 & 46.4 & ) & - & 2.995 & 2.995 & 50 & 88 & 10 & 1.21 & 12 & 50 & \\
\hline - & V1 & 246.5 & & - & 2.995 & 2.995 & 40 & 71 & 8 & 1.21 & 10 & 200 & \\
\hline U & 1 & 250.1 & & 001 & 3.003 & 1.956 & 340 & 601 & 57 & 1.00 & 157 & 3287 & \\
\hline V & 1 & 51.3 & & 010 & .003 & 1.965 & 20 & 35 & 9 & .00 & 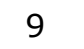 & 92 & \\
\hline Y & V1 & 51.5 & & 120 & 3.003 & 2.069 & 350 & 619 & 144 & .02 & 148 & 102 & \\
\hline 2-V1 & 11 & 256 & & 220 & .000 & 2.159 & 275 & 486 & 104 & 1.04 & 109 & 283 & \\
\hline $2-V 2$ & 11 & 256.5 & & 330 & 3.000 & 2.254 & 300 & 530 & 104 & 1.06 & 111 & 329 & \\
\hline $2-V 3$ & 1 & 257 & & .010 & 3.000 & 1.964 & 290 & 512 & 133 & 1.00 & 133 & 787 & \\
\hline 1 & $\mathrm{~V} 1$ & 253.7 & & .072 & 3.003 & 2.025 & 370 & 54 & 160 & 1.01 & 162 & 393 & \\
\hline 2 & V1 & 253.8 & & 130 & 3.003 & 2.079 & 400 & 7 & 164 & 1.02 & 168 & 521 & \\
\hline 3 & V1 & 255 & & .005 & 3.003 & 1.960 & 110 & 194 & 51 & 1.00 & 50 & 060 & \\
\hline 4 & V1 & 255.5 & & 018 & 3.003 & 1.973 & 180 & 318 & 82 & .00 & 82 & 718 & \\
\hline 5 & V1 & 258.6 & & .980 & 3.003 & 1.936 & 170 & 300 & 80 & 99 & 80 & 671 & \\
\hline 6 & $\mathrm{~V} 1$ & 259 & & 0.970 & 3.003 & 1.926 & 70 & 124 & 33 & .99 & 33 & 594 & \\
\hline 7 & V1 & 259.8 & & .778 & 3.003 & 1.725 & 145 & $\angle 30$ & 86 & 94 & - & 704 & \\
\hline 8 & $\mathrm{~V} 1$ & 260.2 & & .019 & 3.003 & 1.974 & 160 & 283 & 73 & 00 & 73 & 526 & \\
\hline 9 & V1 & 260.8 & & .003 & 3.003 & 1.958 & 170 & 300 & 78 & .00 & 78 & 641 & \\
\hline 10 & V1 & 261.7 & & .010 & 3.003 & 1.965 & 180 & 31 & 82 & 0 & 82 & 728 & \\
\hline 11 & V1 & 262.7 & & 0.915 & 3.003 & 1.870 & 130 & 230 & 66 & 8 & 64 & 348 & \\
\hline 1-R1 & $\mathrm{R}$ & 234 & & .400 & 3.000 & 2.312 & 975 & 723 & 322 & 8 & 346 & 275 & \\
\hline $1-R 2$ & $\mathrm{R}$ & 234.9 & & .733 & 3.000 & 2.573 & 800 & 1414 & 214 & 3 & 41 & 058 & \\
\hline A & $\mathrm{R}$ & 236.1 & & 1.279 & 2.998 & 2.210 & 300 & 530 & 109 & .05 & 14 & 402 & \\
\hline B & $\mathrm{R}$ & 236.2 & & 1.240 & 2.998 & 2.176 & 380 & 672 & 142 & 1.05 & 48 & 116 & \\
\hline C & $\mathrm{R}$ & 236.3 & & .020 & 2.998 & 1.973 & 400 & 707 & 182 & .00 & 82 & 317 & \\
\hline 1-R3 & $\mathrm{R}$ & 238.7 & & 1.867 & 3.000 & 2.670 & 900 & + & 22 & 5 & 66 & 373 & \\
\hline R4 & $\mathrm{R}$ & 238.9 & & .267 & 3.000 & 2.942 & 1100 & 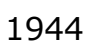 & 2 & & 69 & 650 & \\
\hline R5 & $\mathrm{R}$ & 240 & & .833 & 3.000 & 2.646 & 950 & 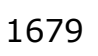 & 240 & 4 & 74 & 751 & \\
\hline$-R 6$ & $\mathrm{R}$ & 242 & & .367 & 3.000 & 2.285 & 800 & 1414 & 271 & 1.07 & 290 & 5081 & \\
\hline- & $\mathrm{R}$ & 236.1 & & - & 2.998 & 2.998 & 200 & בזבי & 39 & & 48 & 998 & \\
\hline- & $\mathrm{R}$ & 236.2 & & - & 2.998 & 2.998 & 180 & 3 & 3 & & & 98 & \\
\hline- & $\mathrm{R}$ & 236.3 & & - & 2.998 & 2.998 & 130 & 23 & 2 & & 3 & 49 & \\
\hline- & $\mathrm{R}$ & 236.4 & & - & 2.998 & 2.998 & 150 & 2 & 29 & & 36 & 48 & \\
\hline D & $\mathrm{R}$ & 243.8 & & .110 & 2.998 & 2.058 & 350 & 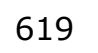 & 146 & 2 & 149 & 128 & \\
\hline$E$ & $\mathrm{R}$ & 244 & & 662 & 2.998 & 2.519 & 600 & 10 & 167 & & 187 & 921 & \\
\hline $\mathrm{F}$ & $\mathrm{R}$ & 244.4 & & .040 & 2.998 & 1.992 & 420 & & 10 & & & 948 & \\
\hline G & $\mathrm{R}$ & 2 & & .058 & 2.998 & 2.010 & 300 & & & & 32 & 782 & \\
\hline $\mathrm{H}$ & $\mathrm{R}$ & 245.7 & & .448 & 2.998 & 2.351 & 500 & 8 & 16 & & 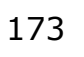 & 3636 & \\
\hline I & $\mathrm{R}$ & 246 & & 5 & 2.998 & 1.9 & 300 & - & 138 & & 8 & 895 & \\
\hline J & $\mathrm{R}$ & 246.1 & & 1.227 & 2.998 & 2.164 & 580 & 1025 & 219 & 04 & 228 & 4796 & \\
\hline- & $\mathrm{R}$ & 243.7 & & - & 2.998 & 2.998 & 120 & & 24 & & 29 & 599 & \\
\hline- & $\mathrm{R}$ & 243.9 & & - & 2.998 & 2.998 & 70 & & 1 & & 1 & 49 & \\
\hline- & $\mathrm{R}$ & 245.6 & & - & 2.998 & 2.998 & 70 & 12 & 14 & 1.21 & 17 & 49 & \\
\hline- & $\mathrm{R}$ & 245.7 & & - & 2.998 & 2.998 & 20 & 35 & 4 & & & 00 & \\
\hline- & $\mathrm{R}$ & 246.1 & D & - & 2.998 & 2.998 & 20 & & 4 & 1.21 & & 00 & \\
\hline 2-R1 & $\mathrm{R}$ & 251 & A & 300 & 3.000 & 2.228 & 430 & & 153 & 1.06 & 162 & 3398 & \\
\hline $2-R_{2}^{2}$ & $\mathrm{R}$ & 251.5 & & 490 & 3.000 & 2.386 & 460 & & 143 & 1.09 & 156 & 3270 & \\
\hline $2-R$ & $\mathrm{R}$ & & & & 3.000 & 2.185 & 41 & & 152 & & & 3340 & \\
\hline K & $R$ & 253.4 & $A$ & 1.205 & 2.998 & 2.145 & 375 & 66 & 144 & 1.04 & 150 & 3144 & \\
\hline $\mathrm{L}$ & $\mathrm{R}$ & 253.5 & A & 1.285 & 2.998 & 2.215 & 250 & 442 & 90 & 1.05 & 95 & 1994 & \\
\hline |VI & 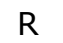 & 253.6 & A & 1.089 & 2.998 & 2.039 & 300 & 530 & 128 & 1.02 & 130 & 2721 & \\
\hline
\end{tabular}




\begin{tabular}{cccccccccccccc}
- & $\mathrm{R}$ & 253.5 & $\mathrm{D}$ & - & 2.998 & 2.998 & 150 & 265 & 29 & 1.21 & 36 & 748 & 138 \\
- & $\mathrm{R}$ & 253.6 & $\mathrm{D}$ & - & 2.998 & 2.998 & 160 & 283 & 31 & 1.21 & 38 & 798 & 138 \\
$\mathrm{~N}$ & $\mathrm{R}$ & 254.7 & $\mathrm{~A}$ & 1.128 & 2.998 & 2.075 & 200 & 353 & 82 & 1.02 & 84 & 1765 & 136 \\
$\mathrm{O}$ & $\mathrm{R}$ & 255.7 & $\mathrm{~A}$ & 1.280 & 2.998 & 2.210 & 360 & 636 & 130 & 1.05 & 137 & 2881 & 136 \\
- & $\mathrm{R}$ & 255.7 & $\mathrm{D}$ & - & 2.998 & 2.998 & 60 & 106 & 12 & 1.21 & 14 & 299 & 136 \\
- & $\mathrm{R}$ & 255.8 & $\mathrm{D}$ & - & 2.998 & 2.998 & 20 & 35 & 4 & 1.21 & 5 & 100 & 136 \\
\hline
\end{tabular}

The statistical analyses for the comparisons of the immediate and main roof strengths of the three tested holes are as follows:

Table A.2. Statistics summary for the immediate roofs

\begin{tabular}{|c|c|c|c|c|c|c|c|}
\hline Hole & $\mathbf{n}$ & Mean $(\mu)$ & Variance $\left(s^{2}\right)$ & Std. Dev. $(s)$ & Median & Min & Max \\
\hline V1 & 8 & 1,637 & 331,760 & 576 & 1,656 & 694 & 2,787 \\
\hline V2 & 9 & 2,254 & $1,292,238$ & 1,137 & 1,750 & 967 & 3,847 \\
\hline $\mathrm{R}$ & 8 & 2,814 & 388,575 & 623 & 3,013 & 1,765 & 3,398 \\
\hline
\end{tabular}

Table A.3. Statistics summary for the main roofs

\begin{tabular}{|c|c|c|c|c|c|c|c|}
\hline Hole & $\mathbf{n}$ & Mean $(\mu)$ & Variance $\left(s^{2}\right)$ & Std. Dev. $(s)$ & Median & Min & Max \\
\hline V1 & 29 & 3,617 & $2,050,011$ & 1,432 & 3,487 & 192 & 6,018 \\
\hline V2 & 21 & 4,073 & $3,228,209$ & 1,797 & 4,737 & 1,010 & 6,434 \\
\hline R & 16 & 4,352 & $1,964,939$ & 1,402 & 3,934 & 2,402 & 7,275 \\
\hline
\end{tabular}

\section{Two sample T-Test:}

- The null hypothesis, $\mathrm{H}_{\mathrm{O}}: \quad \mu_{1}-\mu_{2}=0$

- The alternative hypothesis, $\mathrm{H}_{\mathrm{A}}: \quad \mu_{1}-\mu_{2} \neq 0$

- Reject $\mathrm{H}_{0}$, if $\left|t^{\prime}\right| \geq t_{0.025, v}$

- The calculated t value: $t^{\prime}=\frac{\left(\bar{y}_{1}-\bar{y}_{2}\right)-\left(\mu_{1}-\mu_{2}\right)}{\sqrt{\frac{s_{1}^{2}}{n_{1}}+{\frac{s_{2}}{n_{2}}}^{2}}}$

- $t$ value for $95 \%$ confidence interval: $t_{0.025, v}$ 
- Degrees of Freedom: $v \simeq \frac{\left(\frac{s_{1}{ }^{2}}{n_{1}}+\frac{s_{2}{ }^{2}}{n_{2}}\right)^{2}}{\frac{\left(\frac{s_{1}{ }^{2}}{n_{1}}\right)^{2}}{n_{1}-1}+\frac{\left(\frac{s_{2}{ }^{2}}{n_{2}}\right)^{2}}{n_{2}-1}}$

Table A.4. Comparison of the immediate roofs

\begin{tabular}{|c|c|c|c|c|c|c|c|}
\hline Holes & $\begin{array}{c}\text { Sample } \\
\text { Mean }\end{array}$ & $\begin{array}{c}\text { Standard } \\
\text { Error }\end{array}$ & $\begin{array}{c}\text { Degrees of } \\
\text { Freedom } \\
(\boldsymbol{V})\end{array}$ & $t^{\prime}$ & $\begin{array}{c}t \text { for 95\% } \\
\text { Confidence } \\
t_{0.025, v}\end{array}$ & $\begin{array}{c}\text { Accept } \\
\text { or } \\
\text { Reject } \\
\mathbf{H}_{\mathbf{o}}\end{array}$ & $\begin{array}{c}\text { Percentage } \\
\mathbf{( \% )})\end{array}$ \\
\hline V1 vs. V2 & -616.26 & 430.18 & 12.13 & -1.43 & 2.18 & Accept & 82.28 \\
\hline V1 vs. R & -1176.88 & 300.07 & 13.91 & -3.92 & 2.14 & Reject & 99.84 \\
\hline V2 vs. R & -560.61 & 438.35 & 12.67 & -1.28 & 2.17 & Accept & 77.61 \\
\hline
\end{tabular}

Table A.5. Comparison of the main roofs

\begin{tabular}{|c|c|c|c|c|c|c|c|}
\hline Holes & $\begin{array}{c}\text { Sample } \\
\text { Mean }\end{array}$ & $\begin{array}{c}\text { Standard } \\
\text { Error }\end{array}$ & $\begin{array}{c}\text { Degrees of } \\
\text { Freedom } \\
(\boldsymbol{V})\end{array}$ & $t^{\prime}$ & $\begin{array}{c}t \text { for 95\% } \\
\text { Confidence } \\
t_{0.025, v}\end{array}$ & $\begin{array}{c}\text { Accept } \\
\text { or } \\
\text { Reject } \\
\mathbf{H}_{\mathbf{o}}\end{array}$ & $\begin{array}{c}\text { Percentage } \\
(\mathbf{\%})\end{array}$ \\
\hline V1 vs. V2 & -455.88 & 473.72 & 37.03 & -0.96 & 2.03 & Accept & 65.79 \\
\hline V1 vs. R & -735.02 & 439.88 & 31.62 & -1.67 & 2.04 & Accept & 89.54 \\
\hline V2 vs. R & -279.14 & 525.86 & 34.97 & -0.53 & 2.04 & Accept & 40.11 \\
\hline
\end{tabular}




\section{APPENDIX B}

Table B.1. Slake durability test results

\begin{tabular}{|c|c|c|c|c|c|c|c|c|c|c|}
\hline \multirow[b]{2}{*}{ Mine } & \multirow[b]{2}{*}{ Hole } & \multirow[b]{2}{*}{$\begin{array}{l}\text { Rock } \\
\text { Code }\end{array}$} & \multirow[b]{2}{*}{$\begin{array}{c}\text { Sample } \\
\text { Name }\end{array}$} & \multicolumn{3}{|c|}{ Water Content Calculation } & \multicolumn{2}{|c|}{$1^{\text {st }}$ Cycle Calculation } & \multicolumn{2}{|c|}{$2^{\text {nd }}$ Cycle Calculation } \\
\hline & & & & $\begin{array}{l}\text { Original } \\
\text { Mass } \\
(\mathrm{g}) \\
\end{array}$ & $\begin{array}{c}\text { Dried } \\
\text { Mass } \\
\text { (g) }\end{array}$ & $\begin{array}{c}\text { Water } \\
\text { Content } \\
(\%) \\
\end{array}$ & $\begin{array}{c}\text { Dried Mass } \\
\text { After } 1^{\text {st }} \\
\text { Cycle (g) } \\
\end{array}$ & $\begin{array}{c}\text { SD index } \\
1^{\text {st }} \text { Cycle } \\
I_{d(1)}\end{array}$ & $\begin{array}{c}\text { Dried Mass } \\
\text { After } 2^{\text {nd }} \text { Cycle } \\
(\mathrm{g})\end{array}$ & $\begin{array}{c}\text { SD index } \\
2^{\text {ne }} \text { Cycle } \\
I_{d(1)} \\
\end{array}$ \\
\hline \multirow{11}{*}{$\stackrel{\substack{\underline{\Sigma} \\
\Sigma}}{\Sigma}$} & \multirow{8}{*}{$\frac{\sum_{0}^{-1}}{\frac{0}{0}}$} & V1-110A & VG1-1 & 487.1 & 455.4 & 6.96 & 408.3 & 89.66 & 387.0 & 84.98 \\
\hline & & V1-132A & VG1-2 & 491.6 & 479.9 & 2.44 & 432.7 & 90.16 & 363.7 & 75.79 \\
\hline & & V1-110B & V1-110B-T3 & 106.7 & 101.0 & 5.64 & 98.8 & 97.82 & 92.1 & 91.19 \\
\hline & & V1-132B & V1-132B-T3 & 423.7 & 408.9 & 3.62 & 298.2 & 72.93 & 227.7 & 55.69 \\
\hline & & V1-338 & VG1-T2A & 475.6 & 460.4 & 3.30 & 409.6 & 88.97 & 341.8 & 74.24 \\
\hline & & V1-133 & VG1-3 & 529.8 & 509.1 & 4.07 & 457.2 & 89.81 & 389.5 & 76.51 \\
\hline & & V1-138 & VG1-4 & 593.6 & 583.9 & 1.66 & 562.8 & 96.39 & 532.5 & 91.20 \\
\hline & & V1-333 & VG1-T1 & 472.7 & 469.1 & 0.77 & 452.5 & 96.46 & 432.9 & 92.28 \\
\hline & \multirow{3}{*}{$\begin{array}{l}N \\
\frac{0}{0} \\
\underline{1}\end{array}$} & V2-132 & VG2-1 & 570.8 & 557.8 & 2.33 & 426.9 & 76.53 & 300.1 & 53.80 \\
\hline & & V2-133 & VG2-2 & 525.4 & 514.8 & 2.06 & 448.6 & 87.14 & 340.3 & 66.10 \\
\hline & & V2-138 & VG2-3 & 570.4 & 563.1 & 1.30 & 541.9 & 96.24 & 519.1 & 92.19 \\
\hline \multirow{4}{*}{$\stackrel{\alpha}{\underline{\underline{c}}}$} & \multirow{4}{*}{$\frac{\alpha}{\frac{0}{0}}$} & $\mathrm{R}-136$ & $\mathrm{R}-1$ & 592.3 & 572.0 & 3.55 & 526.1 & 91.98 & 436.9 & 76.38 \\
\hline & & $R-138 A$ & $\mathrm{R}-\mathrm{T} 2 \mathrm{~A}$ & 446.3 & 428.0 & 4.28 & 390.6 & 91.26 & 331.9 & 77.55 \\
\hline & & $\mathrm{R}-138 \mathrm{~B}$ & $\mathrm{R}-2$ & 518.8 & 500.1 & 3.74 & 474.8 & 94.94 & 443.6 & 88.70 \\
\hline & & $\mathrm{R}-333$ & R-T1 & 490.8 & 486.8 & 0.82 & 457.9 & 94.06 & 411.1 & 84.45 \\
\hline
\end{tabular}


Table B.2. Slake durability test detailed results

\begin{tabular}{|c|c|c|c|c|c|c|c|c|c|c|c|c|c|c|c|}
\hline \multirow{3}{*}{ Mine } & \multirow{3}{*}{$\begin{array}{l}\text { Rock } \\
\text { Code }\end{array}$} & \multicolumn{7}{|c|}{$1^{\text {st }}$ Cycle Calculations } & \multicolumn{7}{|c|}{$2^{\text {nd }}$ Cycle Calculations } \\
\hline & & \multirow{2}{*}{$\begin{array}{c}\text { Dried } \\
\text { Mass } \\
\text { After } \\
1^{\text {st }} \\
\text { Cycle } \\
\text { (g) }\end{array}$} & \multicolumn{2}{|c|}{$\begin{array}{l}\text { Materials } \\
\text { Remained } \\
\text { Unchanged }\end{array}$} & \multicolumn{2}{|c|}{$\begin{array}{l}\text { Large \& Small } \\
\text { Fragments }\end{array}$} & \multicolumn{2}{|c|}{$\begin{array}{c}\text { Exclusively } \\
\text { Small } \\
\text { Fragments }\end{array}$} & \multirow{2}{*}{$\begin{array}{l}\text { Dried } \\
\text { Mass } \\
\text { After } \\
2^{\text {nd }} \\
\text { Cycle } \\
\text { (g) }\end{array}$} & \multicolumn{2}{|c|}{$\begin{array}{l}\text { Materials } \\
\text { Remained } \\
\text { Unchanged }\end{array}$} & \multicolumn{2}{|c|}{$\begin{array}{l}\text { Large \& Small } \\
\text { Fragments }\end{array}$} & \multicolumn{2}{|c|}{$\begin{array}{c}\text { Exclusively } \\
\text { Small } \\
\text { Fragments }\end{array}$} \\
\hline & & & (g) & $(\%)$ & (g) & $(\%)$ & (g) & $(\%)$ & & (g) & $(\%)$ & (g) & $(\%)$ & (g) & $(\%)$ \\
\hline \multirow{11}{*}{$\stackrel{\substack{\underline{\Sigma} \\
\Sigma}}{\Sigma}$} & $\mathrm{V} 1-110 \mathrm{~A}$ & 408.3 & 0.00 & 0.00 & 357.60 & 87.58 & 50.70 & 12.42 & 387.0 & 0.00 & 0.00 & 312.40 & 80.72 & 74.60 & 19.28 \\
\hline & V1-132A & 432.7 & 120.80 & 27.92 & 255.20 & 58.98 & 56.70 & 13.10 & 363.7 & 0.00 & 0.00 & 280.80 & 77.21 & 82.90 & 22.79 \\
\hline & V1-110B & 98.8 & 73.50 & 74.39 & 23.00 & 23.28 & 2.30 & 2.33 & 92.1 & 62.90 & 68.30 & 24.30 & 26.38 & 4.90 & 5.32 \\
\hline & V1-132B & 298.2 & 19.80 & 6.64 & 237.00 & 79.48 & 41.40 & 13.88 & 227.7 & 0.00 & 0.00 & 186.10 & 81.73 & 41.60 & 18.27 \\
\hline & V1-338 & 409.6 & 172.69 & 42.16 & 187.92 & 45.88 & 48.99 & 11.96 & 341.8 & 68.98 & 20.18 & 226.85 & 66.37 & 45.97 & 13.45 \\
\hline & V1-133 & 457.2 & 138.60 & 30.31 & 285.40 & 62.42 & 33.20 & 7.26 & 389.5 & 0.00 & 0.00 & 338.70 & 86.96 & 50.80 & 13.04 \\
\hline & V1-138 & 562.8 & 488.90 & 86.87 & 70.40 & 12.51 & 3.50 & 0.62 & 532.5 & 319.60 & 60.02 & 207.20 & 38.91 & 5.70 & 1.07 \\
\hline & V1-333 & 452.5 & 444.81 & 98.30 & 5.66 & 1.25 & 2.04 & 0.45 & 432.9 & 272.94 & 63.05 & 142.73 & 32.97 & 17.23 & 3.98 \\
\hline & V2-132 & 426.9 & 59.30 & 13.89 & 314.50 & 73.67 & 53.10 & 12.44 & 300.1 & 0.00 & 0.00 & 227.60 & 75.84 & 72.50 & 24.16 \\
\hline & V2-133 & 448.6 & 38.30 & 8.54 & 338.90 & 75.55 & 71.40 & 15.92 & 340.3 & 0.00 & 0.00 & 285.70 & 83.96 & 54.60 & 16.04 \\
\hline & V2-138 & 541.9 & 472.30 & 87.16 & 66.60 & 12.29 & 3.00 & 0.55 & 519.1 & 403.20 & 77.67 & 110.90 & 21.36 & 5.00 & 0.96 \\
\hline \multirow{4}{*}{$\begin{array}{l}\mathscr{\alpha} \\
\stackrel{0}{\Sigma}\end{array}$} & $R-136$ & 526.1 & 51.20 & 9.73 & 431.10 & 81.94 & 43.80 & 8.33 & 436.9 & 0.00 & 0.00 & 369.30 & 84.53 & 67.60 & 15.47 \\
\hline & $\mathrm{R}-138 \mathrm{~A}$ & 390.6 & 227.06 & 58.13 & 151.36 & 38.75 & 12.19 & 3.12 & 331.9 & 73.42 & 22.12 & 244.61 & 73.70 & 13.87 & 4.18 \\
\hline & $\mathrm{R}-138 \mathrm{~B}$ & 474.8 & 284.30 & 59.88 & 187.80 & 39.55 & 2.70 & 0.57 & 443.6 & 78.60 & 17.72 & 361.20 & 81.42 & 3.80 & 0.86 \\
\hline & $R-333$ & 457.9 & 297.77 & 65.03 & 149.50 & 32.65 & 10.62 & 2.32 & 411.1 & 106.72 & 25.96 & 287.40 & 69.91 & 16.98 & 4.13 \\
\hline
\end{tabular}




\section{APPENDIX C}

Table C.1. Moisture activity index test detailed results

\begin{tabular}{|c|c|c|c|c|c|c|c|c|c|c|c|}
\hline \multirow[t]{2}{*}{ Mine } & \multirow[t]{2}{*}{ Hole } & \multirow[t]{2}{*}{ Rock Code } & \multirow{2}{*}{$\begin{array}{c}\text { Dried } \\
\text { Mass (g) }\end{array}$} & \multicolumn{2}{|c|}{$\begin{array}{c}\text { Mass at 20\% RH } \\
(\mathrm{g})\end{array}$} & \multicolumn{2}{|c|}{$\begin{array}{c}\text { Mass at 50\% RH } \\
(\mathbf{g})\end{array}$} & \multicolumn{2}{|c|}{$\begin{array}{c}\text { Mass at 80\% RH } \\
(\mathrm{g})\end{array}$} & \multicolumn{2}{|c|}{$\begin{array}{c}\text { Mass at } 100 \% \text { RH } \\
(\mathrm{g})\end{array}$} \\
\hline & & & & Day 1 & Day 6 & Day 7 & Day 17 & Day 18 & Day 33 & Day 34 & Day 53 \\
\hline \multirow{11}{*}{$\begin{array}{l}> \\
\stackrel{\Xi}{\Sigma}\end{array}$} & \multirow{8}{*}{$\begin{array}{l}-1 \\
\frac{0}{0} \\
\frac{1}{1}\end{array}$} & $\mathrm{~V} 1-110 \mathrm{~A}$ & 112.70 & 113.10 & 113.40 & 113.70 & 114.70 & 115.50 & 117.70 & 118.60 & 125.40 \\
\hline & & $\mathrm{V} 1-132 \mathrm{~A}$ & 134.50 & 134.80 & 135.15 & 135.50 & 136.75 & 137.25 & 139.75 & 141.95 & 146.40 \\
\hline & & V1-110B & 206.50 & 207.00 & 207.27 & 207.70 & 209.15 & 209.85 & 213.15 & 215.50 & 222.25 \\
\hline & & V1-132B & 214.60 & 214.90 & 215.20 & 215.80 & 217.10 & 218.20 & 220.90 & 221.90 & 228.10 \\
\hline & & V1-338 & 203.90 & 204.20 & 204.50 & 205.10 & 206.15 & 206.80 & 208.90 & 210.80 & 214.45 \\
\hline & & V1-133 & 202.50 & 202.70 & 203.00 & 203.40 & 204.60 & 205.10 & 207.20 & 208.10 & 212.20 \\
\hline & & V1-138 & 406.80 & 407.60 & 408.00 & 408.50 & 409.90 & 410.65 & 413.70 & 415.05 & 420.00 \\
\hline & & V1-333 & 368.60 & 369.00 & 369.40 & 369.90 & 371.10 & 371.90 & 374.00 & 375.30 & 379.20 \\
\hline & \multirow{3}{*}{$\begin{array}{l}\text { T) } \\
\frac{0}{0} \\
\frac{1}{1}\end{array}$} & V2-132 & 154.30 & 154.70 & 155.00 & 155.40 & 156.30 & 156.80 & 158.55 & 159.55 & 162.80 \\
\hline & & V2-133 & 277.90 & 278.40 & 278.70 & 279.20 & 280.35 & 280.90 & 283.40 & 284.15 & 287.50 \\
\hline & & V2-138 & 424.65 & 425.30 & 425.64 & 426.15 & 427.30 & 428.00 & 430.83 & 431.95 & 435.88 \\
\hline \multirow{4}{*}{$\begin{array}{l}\stackrel{\alpha}{\omega} \\
\stackrel{\Sigma}{\Sigma} \\
\Sigma\end{array}$} & \multirow{4}{*}{ 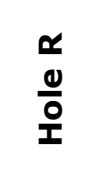 } & $R-136$ & 386.55 & 386.90 & 387.30 & 387.95 & 389.68 & 390.98 & 394.40 & 396.00 & 402.98 \\
\hline & & $R-138 \mathrm{~A}$ & 499.40 & 499.90 & 500.40 & 501.10 & 502.45 & 503.70 & 506.35 & 507.65 & 513.45 \\
\hline & & $R-138 B$ & 468.80 & 469.40 & 469.85 & 470.30 & 471.85 & 472.90 & 475.60 & 477.60 & 480.95 \\
\hline & & $\mathrm{R}-333$ & 365.60 & 366.00 & 366.30 & 366.90 & 368.00 & 369.05 & 371.05 & 371.95 & 375.55 \\
\hline
\end{tabular}




\section{APPENDIX D}

Table D.1. Water (moisture) content calculation results

\begin{tabular}{|c|c|c|c|c|c|}
\hline $\begin{array}{c}\text { Test } \\
\text { Number }\end{array}$ & Hole & $\begin{array}{l}\text { Rock } \\
\text { Code }\end{array}$ & $\begin{array}{c}\text { Original } \\
\text { Mass } \\
(\mathrm{g})\end{array}$ & $\begin{array}{c}\text { Dried } \\
\text { Mass } \\
(\mathrm{g}) \\
\end{array}$ & $\begin{array}{c}\begin{array}{c}\text { Water } \\
\text { Content } \\
(\%)\end{array} \\
\end{array}$ \\
\hline 1 & V1 & $\mathrm{V} 1-110 \mathrm{~A}$ & 487.1 & 455.4 & 6.96 \\
\hline 2 & $\mathrm{~V} 1$ & V1-110A & 120.10 & 112.70 & 6.57 \\
\hline 3 & V1 & V1-132A & 143.50 & 134.50 & 6.69 \\
\hline 4 & V1 & $\mathrm{V} 1-110 \mathrm{~B}$ & 218.80 & 206.50 & 5.96 \\
\hline 5 & V1 & V1-110B & 103.9 & 98.1 & 5.91 \\
\hline 6 & V1 & V1-132B & 423.7 & 408.9 & 3.62 \\
\hline 7 & V1 & V1-338 & 475.6 & 460.4 & 3.30 \\
\hline 8 & V1 & V1-133 & 529.8 & 509.1 & 4.07 \\
\hline 9 & $\mathrm{~V} 1$ & V1-138 & 416.00 & 406.80 & 2.26 \\
\hline 10 & $\mathrm{~V} 1$ & V1-138 & 593.6 & 583.9 & 1.66 \\
\hline 11 & V1 & V1-333 & 375.40 & 368.60 & 1.84 \\
\hline 12 & $\mathrm{~V} 1$ & V1-333 & 472.7 & 469.1 & 0.77 \\
\hline 13 & V2 & V2-132 & 158.30 & 154.30 & 2.59 \\
\hline 14 & $\mathrm{~V} 2$ & V2-132 & 570.8 & 557.8 & 2.33 \\
\hline 15 & V2 & V2-133 & 283.40 & 277.90 & 1.98 \\
\hline 16 & V2 & V2-133 & 525.4 & 514.8 & 2.06 \\
\hline 17 & V2 & V2-138 & 431.40 & 424.65 & 1.59 \\
\hline 18 & V2 & V2-138 & 570.4 & 563.1 & 1.30 \\
\hline 19 & $R$ & $R-136$ & 319.10 & 300.70 & 6.12 \\
\hline 20 & $R$ & $R-136$ & 592.3 & 572.0 & 3.55 \\
\hline 21 & $R$ & $\mathrm{R}-138 \mathrm{~A}$ & 519.70 & 499.40 & 4.06 \\
\hline 22 & $R$ & $R-138 A$ & 446.3 & 428.0 & 4.28 \\
\hline 23 & $\mathrm{R}$ & $\mathrm{R}-138 \mathrm{~B}$ & 487.40 & 468.80 & 3.97 \\
\hline 24 & $\mathrm{R}$ & $\mathrm{R}-138 \mathrm{~B}$ & 518.8 & 500.1 & 3.74 \\
\hline 25 & $\mathrm{R}$ & $R-333$ & 377.30 & 365.60 & 3.20 \\
\hline 26 & $R$ & $R-333$ & 490.8 & 486.8 & 0.82 \\
\hline
\end{tabular}




\section{APPENDIX E}

Table E.1. Weatherability index test results

\begin{tabular}{|c|c|c|c|c|c|c|}
\hline \multirow[b]{2}{*}{ Mine } & \multirow[b]{2}{*}{ Hole } & \multirow[b]{2}{*}{$\begin{array}{c}\text { Sample } \\
\text { Name }\end{array}$} & \multirow[b]{2}{*}{$\begin{array}{c}\text { Ferm } \\
\text { Number }\end{array}$} & \multicolumn{2}{|c|}{ Dry Weight } & \multirow[b]{2}{*}{$\begin{array}{c}\text { Weatherability } \\
\text { Index } \\
(\%)\end{array}$} \\
\hline & & & & $\begin{array}{c}\text { Before } \\
\text { Test } \\
(\mathrm{g})\end{array}$ & $\begin{array}{c}\text { After } \\
\text { Test } \\
(\mathrm{g})\end{array}$ & \\
\hline \multirow{24}{*}{$\begin{array}{l}> \\
\stackrel{0}{\underline{\Sigma}} \\
\stackrel{\Sigma}{\Sigma}\end{array}$} & \multirow{18}{*}{$\begin{array}{l}\frac{5}{0} \\
\frac{0}{0} \\
\frac{0}{1}\end{array}$} & $\mathrm{~V} 1-110-\mathrm{A}-1$ & 110 & 215.7 & 212.7 & 1.39 \\
\hline & & V1-132-A-1 & 132 & 214.5 & 17.7 & 91.75 \\
\hline & & V1-132-A-2 & 132 & 182.3 & 45.1 & 75.26 \\
\hline & & $\mathrm{V} 1-132-\mathrm{A}-3$ & 132 & 179.2 & 16.8 & 90.63 \\
\hline & & V1-110-B-1 & 110 & 112.3 & 110.4 & 1.69 \\
\hline & & $\mathrm{V} 1-132-\mathrm{B}-1$ & 132 & 174.4 & 30.8 & 82.34 \\
\hline & & $\mathrm{V} 1-132-\mathrm{B}-2$ & 132 & 177.4 & 16.5 & 90.70 \\
\hline & & V1-132-B-3 & 132 & 186.8 & 31.0 & 83.40 \\
\hline & & V1-338-1 & 338 & 376.8 & 60.8 & 83.86 \\
\hline & & V1-338-2 & 338 & 529.6 & 73.0 & 86.22 \\
\hline & & V1-338-3 & 338 & 474.9 & 133.2 & 71.95 \\
\hline & & V1-133-1 & 133 & 535.6 & 11.8 & 97.80 \\
\hline & & V1-133-2 & 133 & 762.4 & 294.4 & 61.39 \\
\hline & & V1-133-3* & 133 & 707.4 & 640.8 & 9.41 \\
\hline & & V1-138-1 & 138 & 876.1 & 191.2 & 78.18 \\
\hline & & V1-138-2 & 138 & 802.6 & 159.3 & 80.15 \\
\hline & & V1-333-1 & 333 & 654.1 & 556.3 & 14.95 \\
\hline & & V1-333-2 & 333 & 362.6 & 103.5 & 71.46 \\
\hline & \multirow{6}{*}{$\begin{array}{l}\text { N } \\
\frac{0}{0} \\
\frac{0}{1}\end{array}$} & V2-132-1 & 132 & 210.3 & 32.8 & 84.40 \\
\hline & & V2-132-2* & 132 & 495.9 & 246.5 & 50.29 \\
\hline & & V2-133-1 & 133 & 1050.8 & 189.8 & 81.94 \\
\hline & & V2-133-2 & 133 & 633.3 & 63.0 & 90.05 \\
\hline & & V2-138-1 & 138 & 516.1 & 386.6 & 25.09 \\
\hline & & V2-138-2 & 138 & 450.4 & 287.5 & 36.17 \\
\hline \multirow{7}{*}{$\begin{array}{l}\boldsymbol{\alpha} \\
\stackrel{\boldsymbol{\nu}}{\Sigma} \\
\underline{\Sigma}\end{array}$} & \multirow{7}{*}{$\begin{array}{l}\alpha \\
\frac{\alpha}{0} \\
\frac{\alpha}{1}\end{array}$} & $R-136-1$ & 136 & 368.9 & 89.8 & 75.66 \\
\hline & & $R-136-2$ & 136 & 472.4 & 156.2 & 66.93 \\
\hline & & $R-138-A-1$ & 138 & 580.8 & 119.2 & 79.48 \\
\hline & & $R-138-A-2$ & 138 & 328.9 & 215.1 & 34.60 \\
\hline & & R-138-B-1 & 138 & 656.1 & 129.8 & 80.22 \\
\hline & & $R-138-B-2$ & 138 & 449.0 & 141.5 & 68.49 \\
\hline & & R-333-1 & 333 & 814.6 & 132.1 & 83.78 \\
\hline
\end{tabular}

* Not a representative shale sample and the values are not included in average calculations 

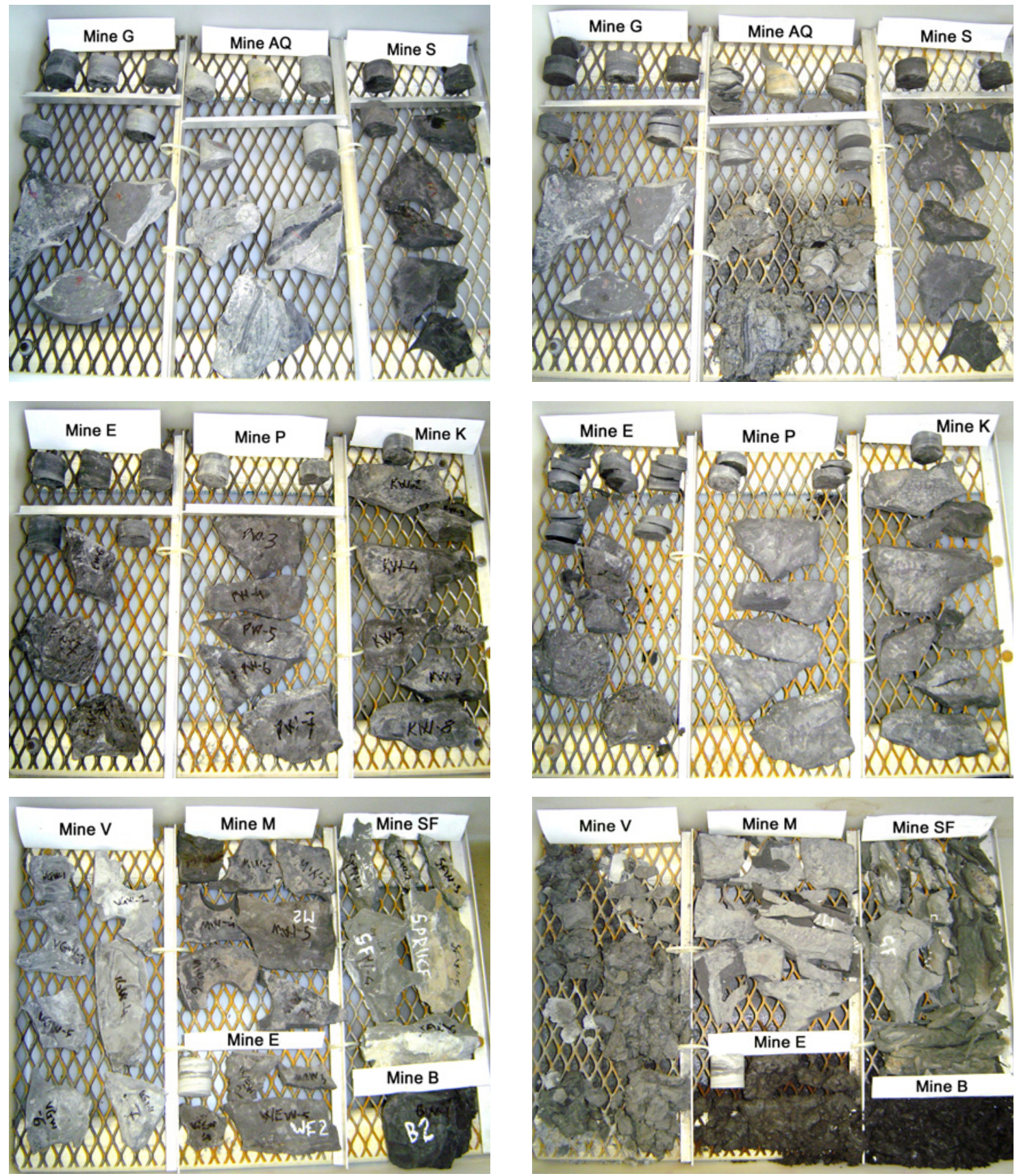

Figure E.1: Before (left hand side) and after (right hand side) weatherability index test of roof rocks of $11 \mathrm{U}$.S. coal mines 


\section{APPENDIX F}

The initial lengths of the specimens before swelling strain test are:

\begin{tabular}{c|c}
$\begin{array}{c}\text { Rock } \\
\text { Code }\end{array}$ & $\begin{array}{c}\text { Initial Length } \\
\text { (in) }\end{array}$ \\
\hline $\mathrm{V} 1-110 \mathrm{~A}$ & 1.171 \\
\hline $\mathrm{V} 1-132 \mathrm{~A}$ & 1.175 \\
\hline $\mathrm{V} 1-110 \mathrm{~B}$ & 1.126 \\
\hline $\mathrm{V} 1-132 \mathrm{~B}$ & 1.184 \\
\hline $\mathrm{V} 1-338$ & 1.590 \\
\hline $\mathrm{V} 1-133$ & 1.220 \\
\hline $\mathrm{V} 2-132$ & 1.273 \\
\hline $\mathrm{V} 2-133$ & 1.432 \\
\hline $\mathrm{R}-136$ & 1.391 \\
\hline $\mathrm{R}-138 \mathrm{~A}$ & 1.686 \\
\hline $\mathrm{R}-138 \mathrm{~B}$ & 1.695
\end{tabular}

Table F.1. Swelling strain test data

\begin{tabular}{|c|c|c|c|c|c|c|c|c|c|c|c|c|}
\hline \multirow{2}{*}{ Day } & \multirow{2}{*}{$\begin{array}{c}\text { RH } \\
(\%)\end{array}$} & \multicolumn{11}{|c|}{ Vertical Displacements $\left(10^{-4}\right.$ in $)$} \\
\hline & & 1-110A & V1-132A & $A$ V1-110B & V1-132B & V1-338 & V1-133 & V2-132 & V2-133 & $R-136$ & $R-138 A$ & $R-138 B$ \\
\hline 0 & - & 0 & 0 & 0 & 0 & 0 & 0 & 0 & 0 & 0 & 0 & 0 \\
\hline 1 & 20 & 0 & 0 & 0 & 5 & 5 & 0 & 0 & 0 & 0 & 0 & 0 \\
\hline 2 & 20 & 0 & 0 & 0 & 5 & 10 & 0 & 0 & 0 & 0 & 5 & 0 \\
\hline 3 & 20 & 0 & 0 & 0 & 5 & 10 & 0 & 0 & 0 & 0 & 5 & 0 \\
\hline 4 & 20 & 0 & 0 & 0 & 5 & 10 & 0 & 0 & 0 & 0 & 5 & 0 \\
\hline 5 & 20 & 0 & 0 & 0 & 5 & 10 & 0 & 0 & 0 & 0 & 5 & 0 \\
\hline 6 & 20 & 0 & 0 & 0 & 5 & 10 & 0 & 0 & 0 & 0 & 5 & 0 \\
\hline 7 & 50 & 5 & 5 & 5 & 10 & 25 & 5 & 5 & 5 & 5 & 15 & 5 \\
\hline 8 & 50 & 5 & 5 & 5 & 15 & 25 & 10 & 5 & 5 & 5 & 15 & 5 \\
\hline 9 & 50 & 5 & 5 & 5 & 20 & 25 & 15 & 10 & 5 & 5 & 15 & 10 \\
\hline 10 & 50 & 5 & 5 & 10 & 20 & 30 & 20 & 10 & 5 & 5 & 15 & 15 \\
\hline 11 & 50 & 5 & 10 & 15 & 20 & 30 & 22 & 10 & 5 & 10 & 20 & 15 \\
\hline 12 & 50 & 5 & 10 & 20 & 20 & 30 & 25 & 10 & 5 & 10 & 20 & 15 \\
\hline 13 & 50 & 10 & 10 & 20 & 20 & 30 & 26 & 15 & 5 & 10 & 25 & 20 \\
\hline 14 & 50 & 10 & 10 & 20 & 25 & 30 & 28 & 15 & 5 & 10 & 25 & 20 \\
\hline 15 & 50 & 10 & 10 & 20 & 25 & 30 & 29 & 15 & 10 & 10 & 30 & 25 \\
\hline 16 & 50 & 10 & 10 & 20 & 25 & 30 & 30 & 15 & 10 & 10 & 30 & 25 \\
\hline
\end{tabular}




\begin{tabular}{|c|c|c|c|c|c|c|c|c|c|c|c|c|}
\hline 17 & 50 & 10 & 10 & 20 & 25 & 30 & 31 & 15 & 10 & 10 & 30 & 25 \\
\hline 18 & 80 & 20 & 30 & 30 & 40 & 65 & 36 & 30 & 20 & 20 & 30 & 25 \\
\hline 19 & 80 & 25 & 40 & 45 & 45 & 75 & 38 & 40 & 20 & 20 & 30 & 25 \\
\hline 20 & 80 & 25 & 45 & 55 & 60 & 75 & 39 & 45 & 20 & 25 & 30 & 25 \\
\hline 21 & 80 & 30 & 50 & 65 & 65 & 80 & 40 & 50 & 20 & 25 & 30 & 25 \\
\hline 22 & 80 & 35 & 55 & 75 & 70 & 80 & 40 & 55 & 20 & 25 & 35 & 25 \\
\hline 23 & 80 & 40 & 60 & 80 & 80 & 85 & 40 & 65 & 20 & 30 & 35 & 30 \\
\hline 24 & 80 & 40 & 60 & 85 & 85 & 85 & 40 & 70 & 20 & 35 & 35 & 30 \\
\hline 25 & 80 & 40 & 60 & 85 & 85 & 85 & 40 & 75 & 25 & 35 & 35 & 30 \\
\hline 26 & 80 & 45 & 65 & 85 & 85 & 85 & 40 & 80 & 25 & 35 & 40 & 30 \\
\hline 27 & 80 & 50 & 70 & 85 & 90 & 85 & 40 & 80 & 25 & 35 & 40 & 30 \\
\hline 28 & 80 & 55 & 70 & 90 & 90 & 90 & 40 & 80 & 25 & 35 & 40 & 35 \\
\hline 29 & 80 & 55 & 75 & 90 & 95 & 90 & 40 & 85 & 25 & 40 & 40 & 35 \\
\hline 30 & 80 & 55 & 80 & 90 & 95 & 95 & 40 & 85 & 25 & 40 & 40 & 35 \\
\hline 31 & 80 & 55 & 80 & 90 & 95 & 95 & 40 & 85 & 25 & 45 & 40 & 35 \\
\hline 32 & 80 & 55 & 80 & 90 & 100 & 95 & 40 & 85 & 25 & 45 & 40 & 35 \\
\hline 33 & 80 & 55 & 80 & 90 & 100 & 95 & 40 & 85 & 30 & 45 & 50 & 40 \\
\hline 34 & 100 & 95 & 155 & 140 & 195 & 195 & 75 & 140 & 65 & 95 & 75 & 60 \\
\hline 35 & 100 & 130 & 185 & 160 & 265 & 245 & 95 & 195 & 85 & 150 & 95 & 75 \\
\hline 36 & 100 & 160 & 240 & 170 & 305 & 280 & 115 & 230 & 105 & 160 & 110 & 90 \\
\hline 37 & 100 & 180 & 285 & 180 & 325 & 310 & 130 & 250 & 120 & 175 & 120 & 105 \\
\hline 38 & 100 & 195 & 300 & 195 & 345 & 340 & 140 & 275 & 130 & 200 & 130 & 120 \\
\hline 39 & 100 & 210 & 350 & 200 & 355 & 365 & 150 & 285 & 140 & 220 & 135 & 140 \\
\hline 40 & 100 & 215 & 375 & 210 & 360 & 380 & 155 & 300 & 150 & 235 & 140 & 155 \\
\hline 41 & 100 & 225 & 385 & 210 & 370 & 410 & 155 & 305 & 155 & 245 & 150 & 165 \\
\hline 42 & 100 & 235 & 415 & 215 & 380 & 445 & 165 & 310 & 165 & 255 & 155 & 175 \\
\hline 43 & 100 & 245 & 430 & 220 & 385 & 460 & 170 & 325 & 170 & 255 & 160 & 180 \\
\hline 44 & 100 & 250 & 445 & 225 & 390 & 470 & 180 & 340 & 180 & 260 & 165 & 190 \\
\hline 45 & 100 & 255 & 460 & 225 & 395 & 480 & 185 & 350 & 185 & 270 & 165 & 200 \\
\hline 46 & 100 & 260 & 470 & 225 & 400 & 490 & 190 & 360 & 190 & 280 & 170 & 205 \\
\hline 47 & 100 & 260 & 480 & 225 & 400 & 495 & 190 & 365 & 190 & 285 & 175 & 210 \\
\hline 48 & 100 & 260 & 485 & 225 & 400 & 500 & 195 & 375 & 195 & 290 & 175 & 210 \\
\hline 49 & 100 & 265 & 495 & 225 & 400 & 505 & 195 & 380 & 195 & 300 & 180 & 215 \\
\hline 50 & 100 & 265 & 500 & 230 & 405 & 510 & 200 & 380 & 200 & 305 & 180 & 215 \\
\hline 51 & 100 & 265 & 505 & 230 & 405 & 510 & 200 & 385 & 200 & 305 & 180 & 215 \\
\hline 52 & 100 & 265 & 505 & 230 & 405 & 510 & 200 & 385 & 200 & 310 & 180 & 220 \\
\hline 53 & 100 & 265 & 505 & 230 & 405 & 510 & 200 & 385 & 200 & 310 & 180 & 220 \\
\hline
\end{tabular}




\section{APPENDIX G}




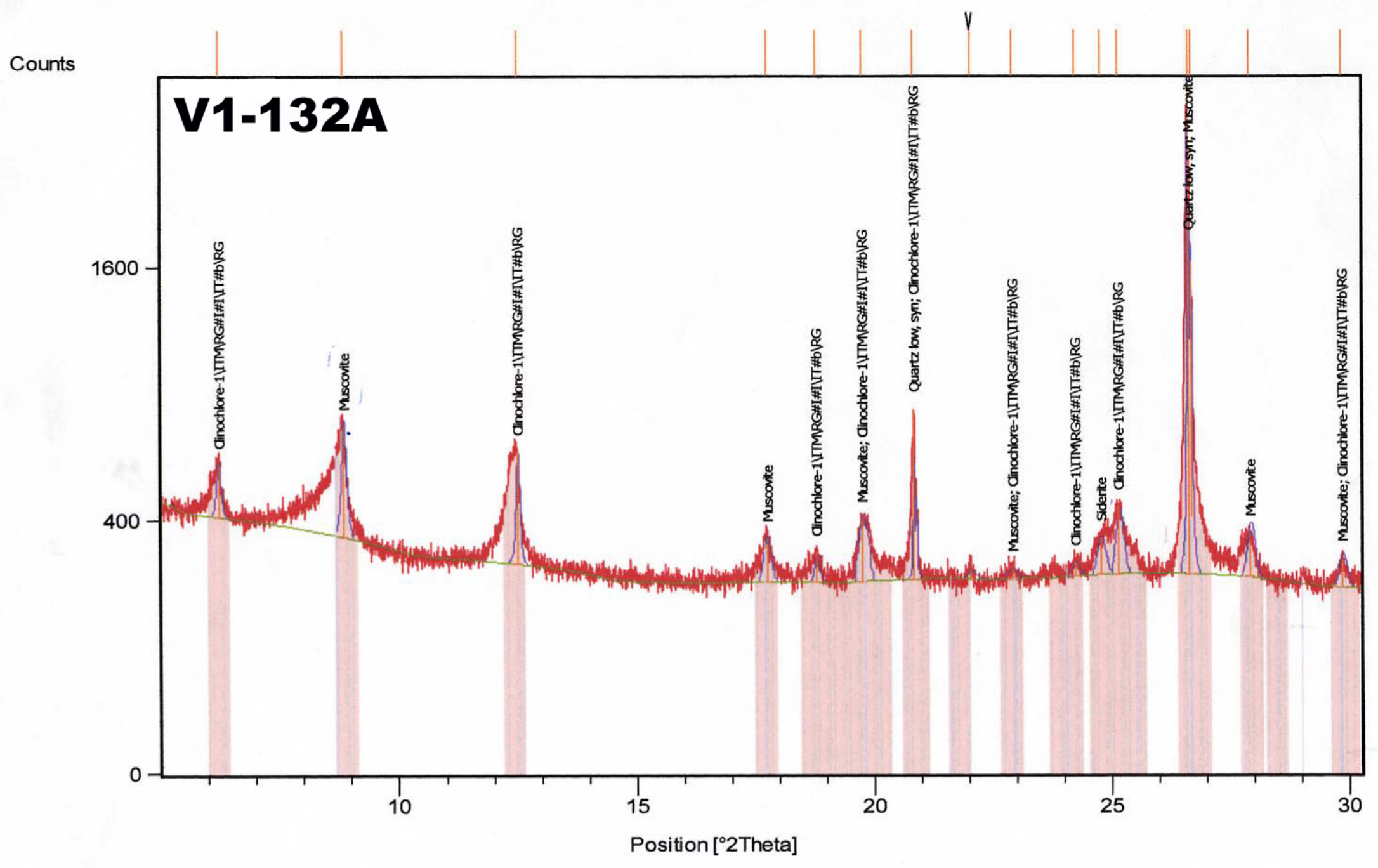

Figure G.1: Mineral composition of V1-132A 


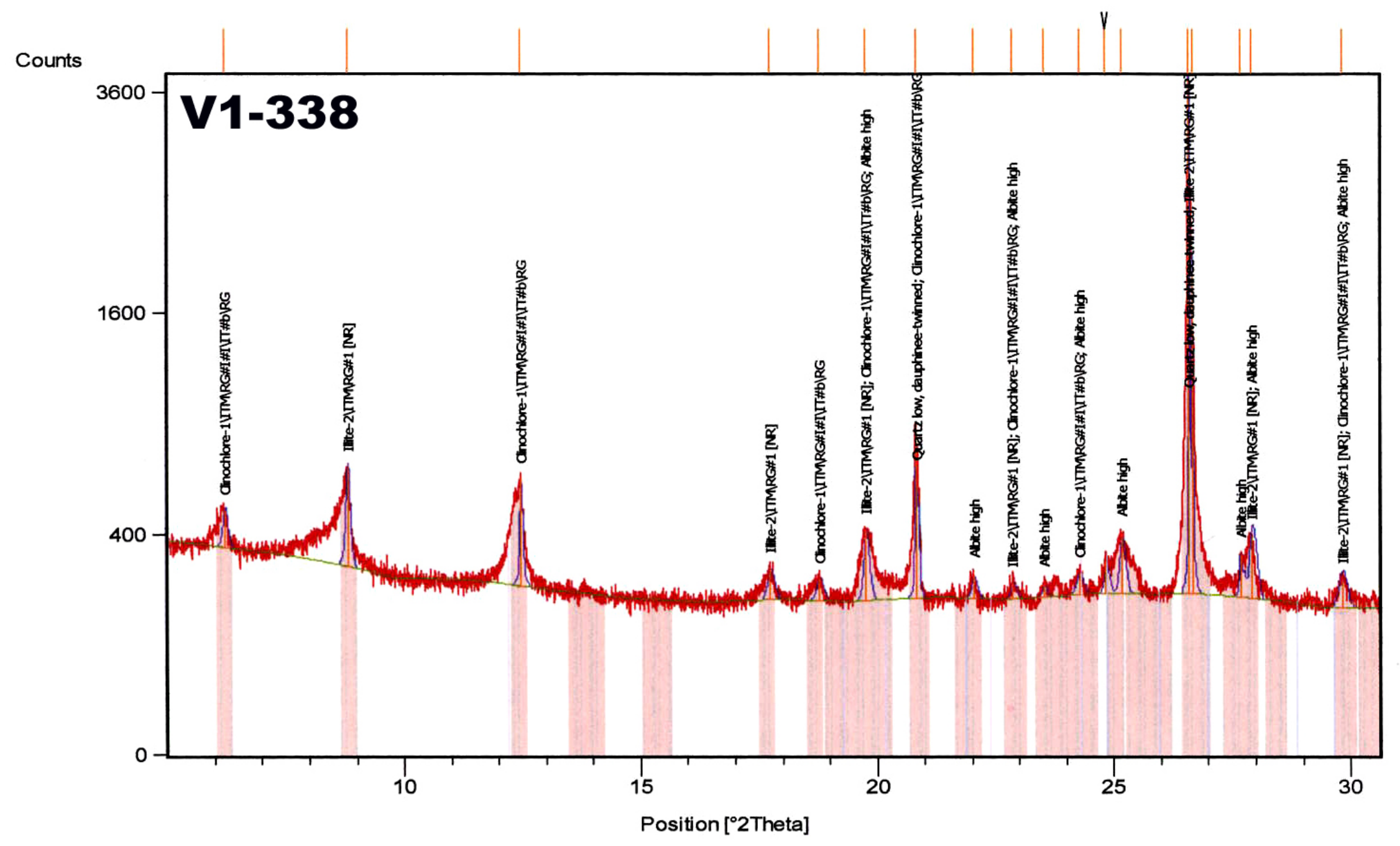

Figure G.2: Mineral composition of V1-338 


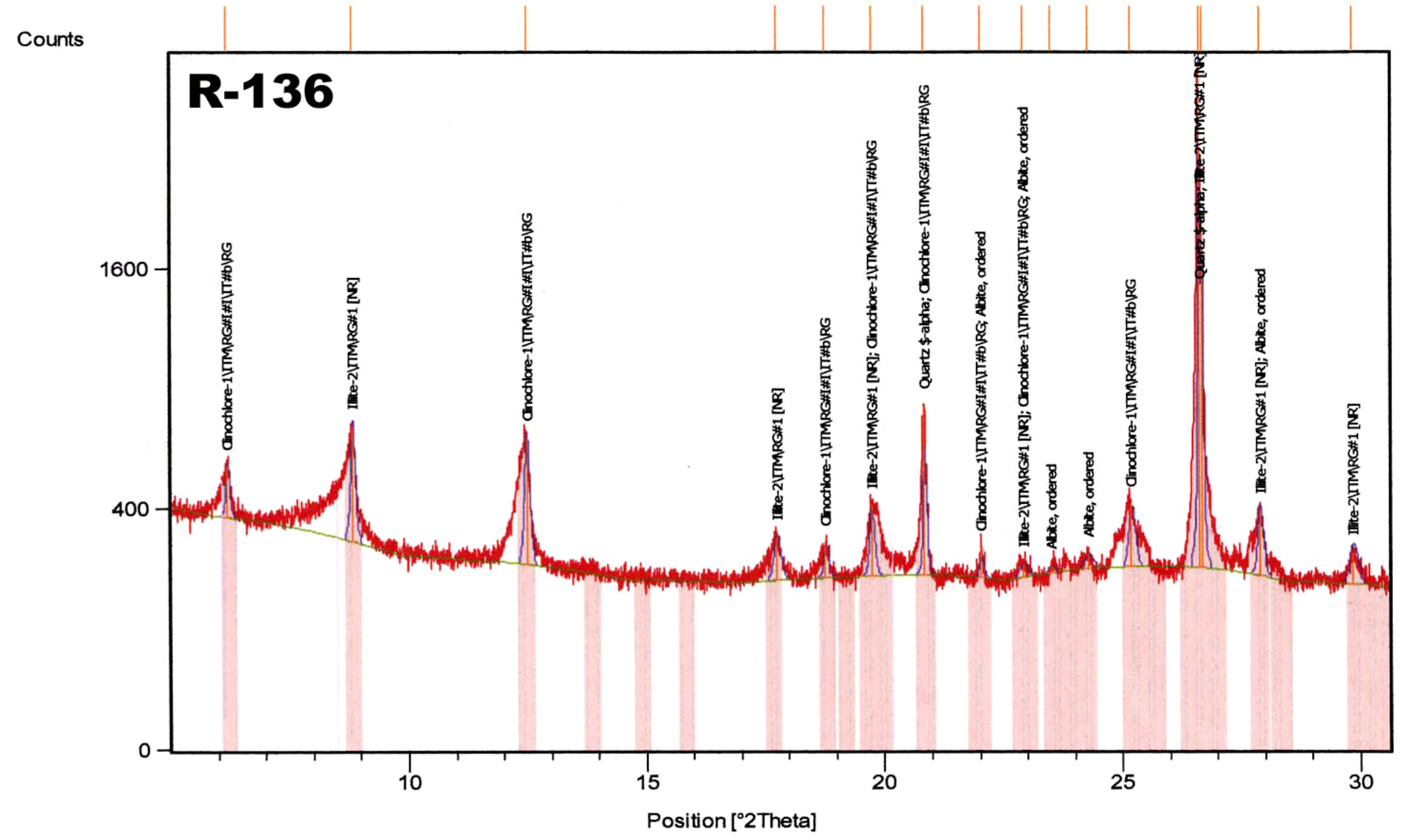

Figure G.3: Mineral composition of R-136 


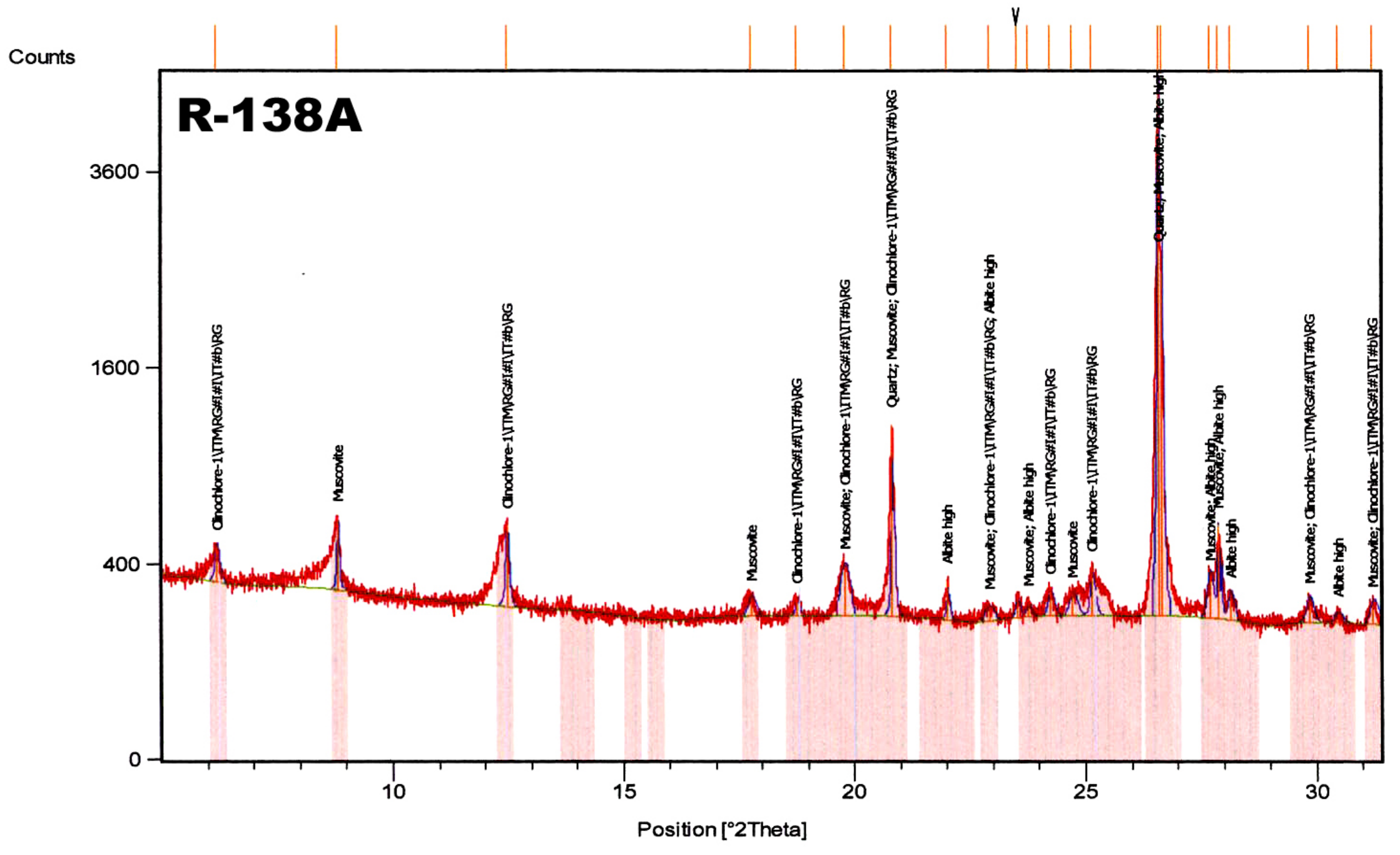

Figure G.4: Mineral composition of R-138A 